\title{
Buku Ajar \\ Pasca Panen dan Pengolahan \\ Sayuran Daun
}

Penulis:

Ida Agustini Saidi

Rima Azara

Evi Yanti

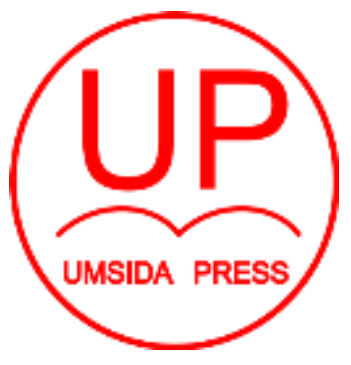

Diterbitkan oleh

\section{UMSIDA PRESS}

Jl. Mojopahit 666 B Sidoarjo

ISBN: 978-623-6292-21-1

Copyright $(2021$.

Authors

All rights reserved 
Buku Ajar

Pasca Panen dan Pengolahan Sayuran Daun

Penulis :

Ida Agustini Saidi

Rima Azara

Evi Yanti

\section{ISBN :}

978-623-6292-21-1

\section{Editor :}

M. Tanzil Multazam,M.Kn

Mahardika Darmawan.K.W,.M.P.d

\section{Copy Editor :}

Wiwit Wahyu Wijayanti

Design Sampul dan Tata Letak :

Mochamad Nashrullah

Penerbit :

UMSIDA Press

\section{Redaksi :}

Universitas Muhammadiyah Sidoarjo

J1. Mojopahit No 666B

Sidoarjo, Jawa TImur

Cetakan pertama, Agustus 2021

(C) Hak cipta dilindungi undang-undang

Dilarang memperbanyak karya tulis ini dengan suatu apapun tanpa ijin tertulis dari penerbit. 


\section{KATA PENGANTAR}

Puji syukur kepada Allah Yang Maha Esa, sehingga Buku Ajar Pasca Panen dan Pengolahan Sayuran Daun ini dapat disusun dengan baik meskipun perlu penyempurnaan lebih lanjut. Buku Ajar Pasca Panen dan Pengolahan Sayuran Daun ini dikhususkan untuk pegangan Mahasiswa Teknologi Pangan Universitas Muhammadiyah Sidoarjo. Mata kuliah prasyarat yang harus diselesaikan sebelum mengambil mata kuliah ini adalah:

1. Pengantar Teknologi Pertanian

2. Pengetahuan Bahan

Indonesia kaya dengan komoditas hasil pertanian khususnya hasil hortikultura seperti aneka ragam buah-buahan dan sayuran. Berbeda dengan produk komersial buah-buahan, produk komersial olahan sayur, terutama sayuran daun hampir boleh dikatakan tidak ada. Sayuran umumnya masih diperdagangkan dalam bentuk segar. Teknologi pengolahan yang diterapkan masih secara minimalis dan sifatnya sangat terbatas. Disisi lain komoditi hortikultura masih melakukan pernafasan setelah panen sehingga apabila selesai dipanen tidak ditangani dengan baik akan segera rusak. Kerusakan ini terjadi akibat pengaruh fisik, kimiawi, mikrobiologi, dan fisiologis. Sehingga perlu penanganan pasca panen dan pengolahan yang tepat untuk memperpanjang umur simpan dari sayuran daun.

Penulisan buku ajar Pasca Panen dan Pengolahan Sayuran Daun ini ditulis dalam 7 BAB yang berisi:

\section{Bab 1 Pendahuluan}

Dalam bab 1 ini dijelaskan secara umum tentang pasca panen dan sifat dari sayuran yang mudah rusak. Fungsi pasca panen dan pengolahan sayuran daun juga dijelaskan dalam bab ini.

\section{Bab 2 Jenis-Jenis Sayuran Daun}

Dalam bab 2 ini dijelaskan berbagai macam jenis sayuran seperti bayam, daun katuk, sawi, kangkung, daun kelor, kubis, dan lain lain. Masing-masing dari jenis sayuran tersebut dijelaskan tentang taksonominya, sifat dari tanaman secara umum, serta kandungan gizi dan manfaatnya bagi kesehatan.

\section{Bab 3 Kualitas Bahan dan Kehilangan Pasca Panen}

Dalam bab 3 ini dijelaskan tentang kualitas sayur pasca panen. Dimana sayuran tersebut masih melakukan aktifitas metabolismenya. Selain menjelaskan tentang kualitas tersebut, dalam bab ini juga menjelaskan tentang kemunduran yang terjadi pasca panen dan kehilangan pasca panen.

\section{Bab 4 Teknologi Pasca Panen untuk Sayuran Daun}

Dalam bab 4 ini dijelaskan tentang berbagai macam teknologi pasca panen untuk sayuran daun. Mulai dari pemanenan, penanganan di lapangan produksi, perlakuan di packing house, pengepakan dan pengemasan, pendinginan dan penyimpanan, dan transportasi.

\section{Bab 5 Teknologi Pengolahan Sayuran Daun I}

Dalam bab 5 ini dijelaskan tentang teknologi pengolahan sayuran daun mulai dari perlakuan pra pengolahan, pembekuan, pengalengan, dan pengeringan (dehidrasi). 


\section{Bab 6 Teknologi Pengolahan Sayuran Daun II}

Dalam bab 6 ini dijelaskan tentang teknologi pengolahan sayuran menjadi produk makanan tertentu. Pengolahan sayuran daun dapat dilakukan dengan melakukan proses fermentasi, dan juga bisa dijadikan produk olahan seperti sauerkraut dan pembuatan acar (pickles).

\section{Bab 7 Berbagai Jenis Olahan Sayuran Daun}

Dalam bab 7 ini dijelaskan tentang berbagai jenis olahan sayuran daun dari dua bahan baku yang sering digunakan yaitu kubis dan sawi. Dari dua bahan tersebut dapat dijadikan menjadi berbagai macam olahan sayuran daun seperti mie, tepung, dan lain sebagainya.

Dengan selesainya penulisan buku ajar ini penulis mengucapkan terima kasih kepada semua pihak yang telah memberikan bahan-bahan tulisan baik langsung maupun tidak langsung. Penulis juga mengucapkan terima kasih khususnya kepada:

1. Dr. Hidayatullah, M.Si pemangku pimpinan tertinggi yaitu Rektor Universitas Muhammadiyah Sidoarjo yang telah memberikan dan memfasilitasi dalam penulisan buku ajar ini.

2. LP3iK Universitas Muhammadiyah Sidoarjo yang telah memfasilitasi dan mengkoordinasi dalam penulisan buku ajar ini.

3. Dr. Hindarto, S.Kom., MT sebagai Dekan Fakultas Sains dan Teknologi, Universitas Universitas Muhammadiyah Sidoarjo yang telah memberikan dukungan dalam penulisan buku ajar ini.

4. Lukman Hudi, S.TP., M.MT sebagai Kepala Program Studi Teknologi Pangan, Universitas Universitas Muhammadiyah Sidoarjo yang telah memberikan dukungan dan masukan dalam penulisan buku ajar ini.

5. Para dosen Teknologi Pangan yang telah banyak membantu dalam penyusunan penulisan buku ajar ini.

Akhir kata, kritik dan saran sangat diharapkan untuk penyempurnaan buku ajar ini. Harapan kami semoga buku ajar ini dapat digunakan sebagai bahan belajar dan bermanfaat bagi aktivitas pembelajaran mata kuliah Teknologi Pasca Panen di Program Studi Teknologi Pangan, Fakultas Sains dan Teknologi, Universitas Muhammadiyah Sidoarjo. 


\section{DAFTAR ISI}

KATA PENGANTAR ................................................................................................i

DAFTAR ISI ...................................................................................................ii

BAB I PENDAHULUAN .....................................................................................1

BAB II JENIS-JENIS SAYURAN DAUN ..........................................................4

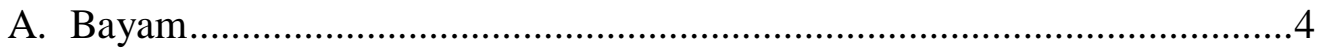

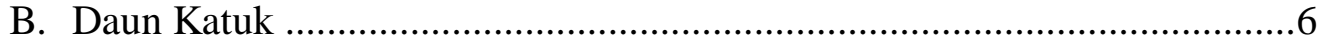

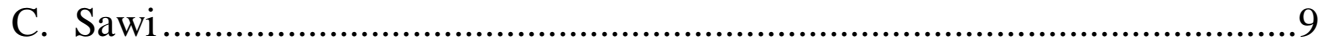

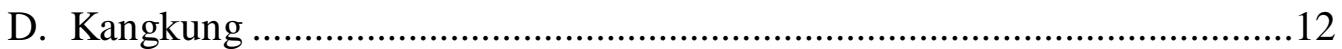

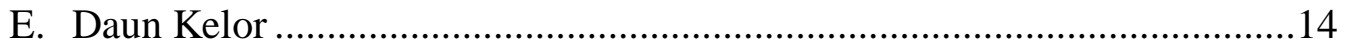

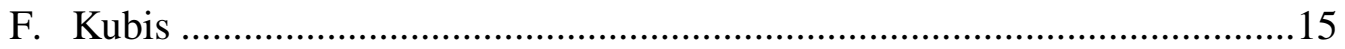

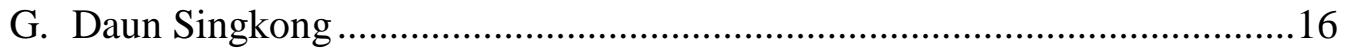

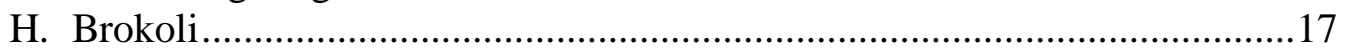

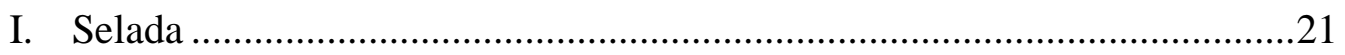

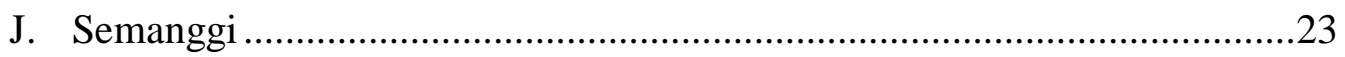

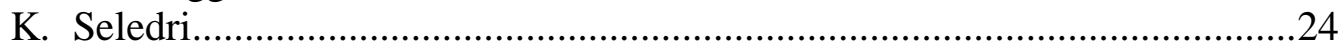

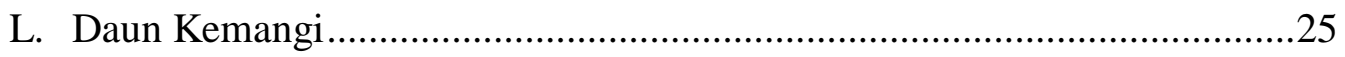

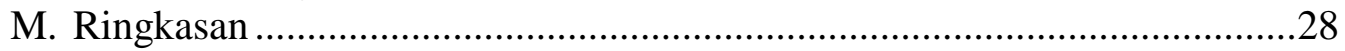

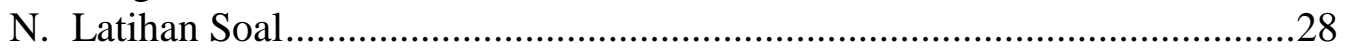

BAB III KUALITAS BAHAN DAN KEHILANGAN PASCA PANEN ...........31

A. Faktor Kualitas .................................................................................

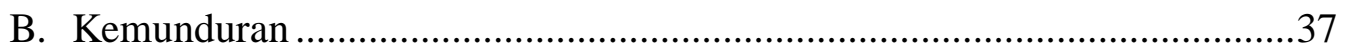

C. Kehilangan Pasca Panen.............................................................................42

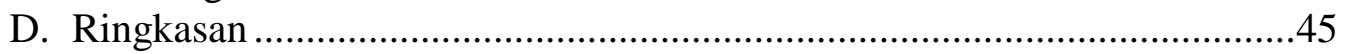

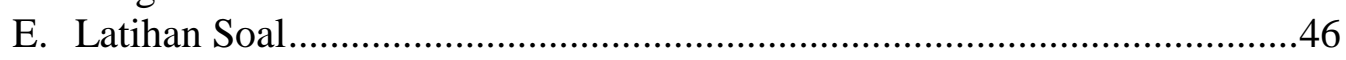

BAB IV TEKNOLOGI PASCA PANEN UNTUK SAYURAN DAUN..............49

A. Pemanenan ………………………………………………….....

B. Penanganan di Lapangan Produksi...........................................................55

C. Perlakuan di Packing House ...................................................................55

D. Pengepakan dan Pengemasan................................................................56

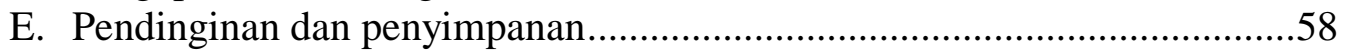

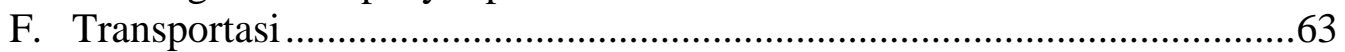

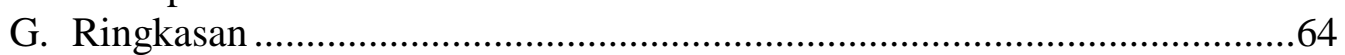

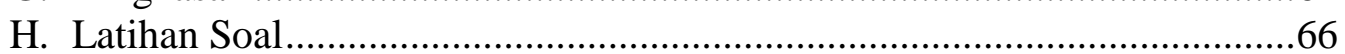

BAB V TEKNOLOGI PENGOLAHAN SAYURAN DAUN I............................69

A. Perlakuan Pra Pengolahan .....................................................................69

B. Pembekuan ....................................................................................

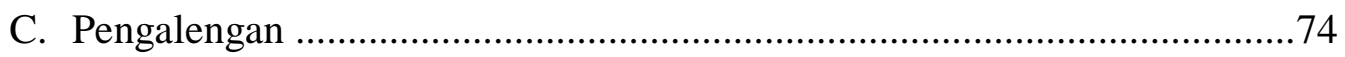

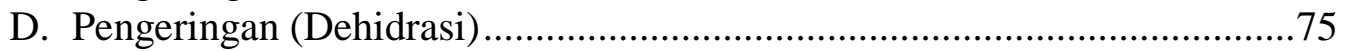

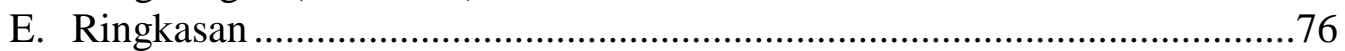

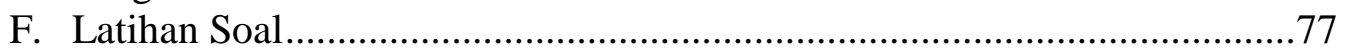

BAB VI TEKNOLOGI PENGOLAHAN SAYURAN DAUN II ........................79

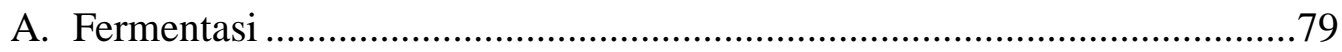

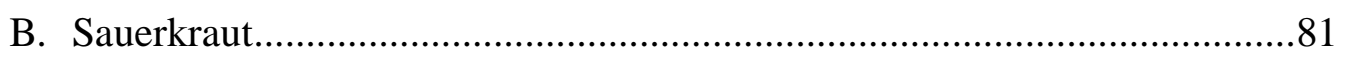

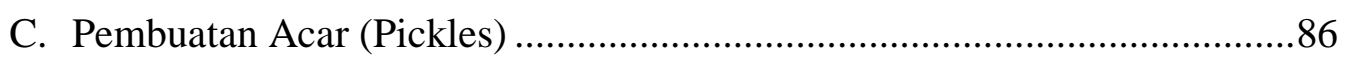

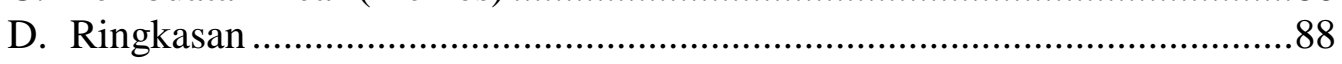




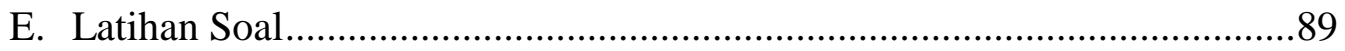

BAB VII BERBAGAI JENIS OLAHAN SAYURAN DAUN .............................90

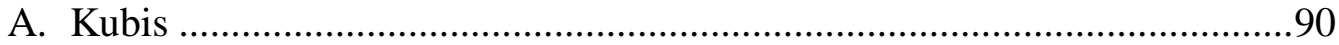

B. Sawi

DAFTAR PUSTAKA .........................................................................................110

BIODATA PENULIS ............................................................................................115 


\section{BAB I \\ PENDAHULUAN}

Indonesia kaya dengan komoditas hasil pertanian khususnya hasil hortikultura seperti aneka ragam buahbuahan dan sayuran. Di antara buah-buahan tersebut terdapat tiga jenis komoditas utama yang terbanyak yaitu pisang, jeruk, dan mangga. Selain dipasarkan dalam bentuk segar, tiga jenis komoditas tersebut juga diolah menjadi kripik, ledre, getuk, jus, puree, sale, jam, dan lain sebagainya. Hampir sebagian besar produk sudah dibuat pada skala komersial (UKM) dengan bukti telah adanya produk tersebut di pasar.

Berbeda dengan produk komersial buah-buahan, produk komersial olahan sayur, terutama sayuran daun hampir boleh dikatakan tidak ada. Sayuran umumnya masih diperdagangkan dalam bentuk segar. Teknologi pengolahan yang diterapkan masih secara minimalis dan sifatnya sangat terbatas. Disisi lain komoditi hortikultura masih melakukan pernafasan setelah panen sehingga apabila selesai dipanen tidak ditangani dengan baik akan segera rusak. Kerusakan ini terjadi akibat pengaruh fisik, kimiawi, mikrobiologi, dan fisiologis. Di Indonesia, hortikultura yang tidak dapat dimanfaatkan diistilahkan sebagai "kehilangan" (losses) mencapai $25-40 \%$, nilai ini sangat besar bila dibandingkan dengan negara-negara maju dengan tingkat kehilangan dibawah $25 \%$.

Penanganan yang kurang baik menyebabkan produk hortikultura terutama sayuran banyak kehilangan nilai ekonominya. Penanganan pasca panen sayur yang umumnya dikonsumsi dalam bentuk segar bertujuan untuk mempertahankan kondisi segarnya dan mencegah 
perubahan-perubahan yang tidak dikehendaki selama penyimpanan seperti pertumbuhan akar dan kehilangan air. Dalam proses penanganan sayuran, diperlukan pengetahuan dasar yaitu fisiologi dan teknologi penanganan pasca panen. Pengetahuan dasar ini berguna dalam membahas mengapa terjadi kerusakan pada sayuran dan tindakan apa yang dapat dilakukan untuk mencegah kerusakan tersebut.

Selain itu kelebihan produksi pada masa panen raya, dimana biasanya komoditi dalam bentuk segar tidak dapat terserap semua, perlu dipikirkan penanganannnya. Dalam hal ini dirasa perlu untuk memikirkan teknologi terapan yang tepat guna, khususnya di daerah sentra produksi. Mengingat pentingnya sayuran sebagai sumber serat, vitamin, dan mineral, maka perlu dilakukan berbagai usaha pengolahan untuk mengurangi, mencegah, atau menghambat terjadinya kerusakan sehingga dapat memperpanjang masa simpannya.

Penambahan daya simpan komoditi sayuran lebih ditekankan dalam hal pengolahan. Alternatif pengolahannya meliputi blansing (pra pengolahan), penggaraman, fermentasi, pembuatan acar, pengalengan, dan pengeringan. Alternatif-alternatif pengolahan sayuran akan diuraikan lebih lanjut pada bab 4 dalam buku ini.

Teknologi pasca panen adalah tindakan atau perlakuan yang diberikan pada setiap komoditas sejak dari panen sampai tiba di tangan konsumen. Teknologi pasca panen menjadi kebutuhan utama dalam mempertahankan dan meningkatkan harga jual produk. Sistem Good Handling Practice (GHP) adalah salah satu cara untuk meminimalkan tingkat kerusakan produk pertanian setelah panen. Penerapan GHP mengurangi resiko kontaminasi produk segar selama penanganan, pengemasan, penyimpanan dan transportasi. Proses yang disediakan harus sesuai dengan 
karakteristik produk. Berbagai inovasi teknologi yang dapat diterapkan untuk menjamin keberhasilan GHP. Selain GHP, perlu juga diterapkan Good Manufactirung Practice (GMP) pada proses pasca panen, karena GMP merupakan kegiatan pengolahan hasil pertanian secara baik dan benar sehingga menghasilkan produk olahan yang aman untuk dikonsumsi masyarakat. Penerapan GMP adalah untuk meningkatkan daya saing olahan hasil pertanian dan meningkatkan mutu produk olahan yang akan mempengaruhi nilai jual suatu produk. 
BAB II

JENIS-JENIS SAYURAN DAUN

\section{A. Bayam}

Bayam (Amaranthus sp.) merupakan tanaman sayur yang dipromosikan sebagai bahan pangan sumber protein. Klasifikasi bayam dapat dilihat sebagai berikut:

$\begin{array}{ll}\text { Kingdom } & \text { : Plantae } \\ \text { Divisi } & \text { : Magnoliophyta } \\ \text { Kelas } & \text { : Magnoliophyta } \\ \text { Ordo } & : \text { Amaranthaceae } \\ \text { Famili } & : \text { Amaranthaceae } \\ \text { Sub famili } & : \text { Amaranthoideae } \\ \text { Genus } & : \text { Amaranthus } \\ \text { Spesies } & : \text { Amaranthus hybridus, A. tricolor, A. } \\ & \text { blitum, A. spinosus }\end{array}$

Bayam memiliki beberapa macam jenis namun yang paling sering dibudidayakan serta sering ditemukan dikalangan masyarakat adalah jenis bayam Amaranthus tricolor L. Jenis bayam ini memiliki dua macam varietas yaitu bayam hijau dan bayam merah. Dari masing-masing bayam tersebut memiliki kandungan zat besi dan mineral yang tinggi yang tentunya baik untuk kesehatan.

Kandungan nutrisi yang cukup tinggi pada bayam dan rasanya yang cukup lezat menjadikan bayam sebagai salah satu komoditas sayuran yang banyak diminati masyarakat untuk dikonsumsi. Konsumsi bayam di Indonesia mengalami peningkatan dari tahun ke tahun. Budidaya bayam pun cukup mudah dilakukan. Bayam biasa diperbanyak secara generatif yaitu melalui bijinya. Bayam dapat dibudidayakan di tanah ber-pH netral baik di dataran tinggi maupun rendah. 
Tanaman bayam sangat reaktif terhadap ketersediaan air didalam tanah.

Tanaman bayam memiliki ciri-ciri morfologi sebagai berikut:

1. Akar

Bayam memiliki perakaran tunggang dan serabut ke samping yang kuat, tegak dan agak dalam, akar bayam berwarna putih.

2. Batang

Batang bayam umumnya tegak, tetapi ada pula jenis bayam yang batangnya menjalar, ada yang batangnya bercabang ada pula yang tidak bercabang. Warna batang juga ada yang hijau, merah, kuning atau kombinasinya.

3. Biji

Biji bayam berbelah dua, warna kulit biji hitam atau coklat tua. Dari setiap tandan (malai) bunga dapat dihasilkan ratusan hingga ribuan biji. Ukuran biji sangat kecil, bentuknya bulat dan berwarna coklat tua mengkilap sampai hitam kelam, namun pada varietas maksi bijnya berwarna putih sampai krem.

4. Daun

Tanaman bayam berdaun tunggal, berbentuk bulat telur dengan ujung agak meruncing dan urat-urat daun yang jelas. Warna daun bervariasi mulai dari hijau muda, hijau tua, hijau keputihputihan, sampai berwarna merah.

5. Bunga

Bunga pada tanaman bayam tersusun majemuk tipe yang rapat, bunga bayam berukuran sangat kecil, terdiri dari daun bunga 4-5 buah, benang 
sari 1-5 buah, dan bakal buah 2-3 buah. Bunga keluar dari ujung-ujung tanaman atau ketiak daun yang tersusun seperti malai yang tumbuh tegak. Tanaman bayam dapat tumbuh sepanjang musim. Perkawinan bersifat unisexual yaitu dapat menyerbuk sendiri maupun menyerbuk silang. Penyerbukan berlangsung dengan bantuan angin dan serangga.

Keunggulan nilai nutrisi sayuran bayam terutama pada kandungan vitamin A (betakaroten), vitamin C, riboflavin dan asam amino thiamine dan niacin. Kandungan terpenting dalam bayam adalah kalsium dan zat besi.

B. Daun katuk

Tanaman katuk (Sauropus androgynus) merupakan tanaman semak kecil yang biasa ditanam sebagai tanaman pagar dan pembatas kebun. Di Indonesia, katuk memiliki beberapa nama antara lain: simani (Minangkabau), katuk (Sunda), babing, katukan, katu (Jawa), kerakur (Madura), katuk (Bengkulu), dan kayu manis (Bali). Katuk mempunyai taksonomi sebagai berikut:

$\begin{array}{ll}\text { Divisi } & \text { : Spermatophyta } \\ \text { Anak divisi } & \text { : Angiospermae } \\ \text { Kelas } & \text { : Dicotyledoneae } \\ \text { Bangsa } & \text { : Graniales } \\ \text { Suku } & \text { : Euphorbiaceae } \\ \text { Anak suku } & \text { : Phyllanthoideae } \\ & \text { : Phyllant } \\ \text { Marga } & \text { : Sauropus } \\ \text { Jenis } & \text { :Sauropus androgynus L. Merr }\end{array}$


Tanaman katuk memiliki ciri-ciri morfologi sebagai berikut:

1. Batang

Batang memiliki alur-alur dengan kulit agak licin. Batang muda berwarna hijau dan yang tua coklat.

2. Daun

Daun menyusun selang seling pada satu tangkai dengan jumlah daun per cabang 11-21 helai, bentuk helaian daun lonjong sampai bundar. Kadang-kadang lanset permukaan atasnya berwarna hijau gelap dan permukaan bawah berwarna hijau muda dengan tampak pertulangan daun yang jelas, panjang helai 2,5 $\mathrm{cm}$, lebar 1,25-3 cm; tangkai pendek 2-4 mm, berdaun penumpu, panjang 1,75-3 $\mathrm{mm}$. Daun yang di pangkal cabang berbentuk bulat telur berukuran lebar $1,5-2,5 \mathrm{~cm}$, panjang $2,5-4,5 \mathrm{~cm}$, sedangkan yang di tengah dan ujung berbentuk jorong berukuran lebar 2,2-3,1 cm, panjang 4,3$8,5 \mathrm{~cm}$.

3. Bunga

Bunga tunggal atau berkelompok 3 , keluar di ketiak daun atau diantara satu daun dengan daun lainnya. Bunga sempurna mempunyai helaian kelopak berbentuk bundar, warna merah gelap atau merah dengan bintik-bintik kuning, lebar 3$3,5 \mathrm{~mm}$, tinggi putik $0,75 \mathrm{~mm}$, lebar $1,75 \mathrm{~mm}$, cabang dari tangkai putik berwarna merah, tepi kelopak bunga berombak atau berkuncup 6, panjang tangkai 6-7,5 mm. Bunga jantan bentuk seperti giwang, kelopak dan mahkotanya serupa, berwarna merah kecoklatan, masing-masing berjumlah 3, saling berdekatan, tebal dan 
berdaging, berwarna hijau kemerahan. Benangsari 6, dengan serbuk sari berwarna putih kekuningan.

Daun katuk kaya akan zat besi, provitamin A dalam bentuk $\beta$-karoten, vitamin $C$, minyak sayur, protein dan mineral. Depkes (1992) melaporkan bahwa dalam $100 \mathrm{~g}$ daun katuk segar mengandung energi 59 kalori, protein 6,4 g, lemak 1,6 g, karbohidrat 9,9 g, serat 1,5 g, abu 1,7 g, kalsium $233 \mathrm{mg}$, fosfor $98 \mathrm{mg}$, besi 3,5 mg, $\beta$-karoten $10020 \mu \mathrm{g}$, vitamin C $164 \mathrm{mg}$, dan air 81 gram. Sedangkan tepung daun katuk mengandung $12 \%$ air, 8,91\% abu, 26,32\% lemak, protein 23,13\%, karbohidrat 29,64\%, karoten 372,42 $\mathrm{mg} / 100 \mathrm{~g}$, dan energi 447,96 kal.

Daun katuk kaya asam palmitat $(33,246 \%)$, asam oleat $(21,391 \%$ dan asam linoleat $(21,081 \%)$. Selain itu, daun katuk juga kaya akan asam glutamat. Daun katuk dapat dimanfaatkan untuk mencegah berbagai penyakit akibat kekurangan zat gizi. Selain itu, daun katuk juga dapat dijadikan obat herbal sebagai anti kuman, antioksidan, dan kolesterol (anti lemak). Manfaat lain daun katuk juga dipercaya dapat memperbanyak produksi ASI (air susu ibu).

Meskipun katuk mengandung zat-zat gizi yang amat bermanfaat bagi kesehatan manusia dan hewan, tetapi sebagaimana bahan pangan lain ia juga mempunyai zat anti nutrisi. Dalam jaringan parenkim daun (palisade dan jaringan bunga karang) ditemukan banyak kristal kalsium oksalat yang dapat mengendap dalam tubuh sehingga berbahaya bagi penderita penyakit batu ginjal. Katuk juga bersifat memperkuat kontraksi otot pada uterus dan usus. Peningkatan kontraksi otot pada uterus (rahim) dapat mengakibatkan keguguran. Karena itu, wanita hamil sebaiknya menghindari konsumsi daun katuk. 


\section{Sawi}

Tanaman Sawi (Brassica juncea) merupakan salah satu jenis sayuran famili kubis-kubisan (Brassicaceae) yang diduga berasal dari negeri China. Sawi masuk ke Indonesia sekitar abad ke -17, namun sayuran ini sudah cukup populer dan diminati di kalangan masyarakat.

Sawi hijau merupakan tanaman yang dapat tumbuh pada dataran rendah maupun dataran tinggi. Pada umumnya, sawi hijau dapat tumbuh baik di tanah yang subur, kaya humus, serta drainase tanah yang baik. Keasaman atau $\mathrm{pH}$ tanah yang dibutuhkan adalah 6-7. Waktu tanam yang baik adalah pada akhir musim hujan. Namun, sawi hijau dapat pula ditanam pada musim kemarau asalkan tersedia cukup air. Sawi mempunyai taksonomi sebagai berikut:

$\begin{array}{ll}\text { Divisi } & \text { : Spermatophyta } \\ \text { Sub divisi } & \text { : Angiospermae } \\ \text { Kelas } & \text { : Dicotyledoneae } \\ \text { Ordo } & \text { : Rhoeadales (Brassicales) } \\ \text { Famili } & \text { : Cruciferae (Brassicaceae) } \\ \text { Genus } & \text { : Brassica } \\ \text { Spesies } & : \text { Brassica juncea } \mathrm{L} .\end{array}$

Di Indonesia penyebutan sawi biasanya mengacu pada sawi hijau (Brassica rapa kelompok parachinensis, yang disebut juga sawi bakso, caisim, atau caisin). Selain itu, terdapat pula sawi putih (Brassica rapa) kelompok pekinensis, disebut juga petsai yang biasa dibuat sup atau diolah menjadi asinan. Jenis lain yang kadang-kadang disebut sebagai sawi hijau adalah sawi sayur (untuk membedakannya dengan caisim). Kailan (Brassica oleracea) kelompok alboglabra adalah sejenis sayuran daun lain yang agak berbeda, karena daunnya lebih tebal dan lebih cocok menjadi 
bahan campuran mi goreng. Sawi sendok (pakcoy atau bok choy) merupakan jenis sayuran daun kerabat sawi yang mulai dikenal pula dalam dunia boga Indonesia.

Tanaman sawi memiliki ciri-ciri morfologi sebagai berikut:

1. Akar

Tanaman sawi hijau berakar serabut yang tumbuh dan berkembang menyebar ke semua arah di sekitar permukaan tanah, perakarannya sangat dangkal pada kedalaman $5 \mathrm{~cm}$. Perakaran tumbuh dan berkembang dengan baik pada tanah yang gembur, subur, tanah yang mudah menyerap air, dan kedalaman tanah yang cukup dalam.

2. Batang

Batang tanaman sawi berupa batang pendek, sehingga hampir tidak kelihatan. Batang ini berfungsi sebagai alat pembentuk dan penopang daun.

3. Daun

Sawi hijau berdaun lonjong (elips) dengan bagian ujung biasanya tumpul, halus, tidak berbulu dan tidak berkrop. Pola pertumbuhan daunnya berserat (roset) hingga sukar membentuk krop. Warna daun hijau segar mengkilap, Tangkai daun berwarna putih atau hijau muda.

4. Bunga

Bunga sawi tersususn dalam tangkai bunga (inflorescentia) yang tumbuh memanjang (tinggi) dan bercabang banyak. Tipe kuntumnya terdiri atas empat helaai kelopak, empat helai mahkota 
bunga yang berwarna kuning, empat benag sari dan satu buah putik berongga.

5. Buah

Buah sawi berupa buah dengan tipe buah polong, bentuknya memanjang dan berongga. Tiap buah (polong) berisi 2-8 buah biji sawi.

6. Biji

Biji sawi berukuran kecil dan berwarna hitam kecoklatan. Bijinya terdapat di kedua sisi dinding sekat polong yang gemuk.

Selain memiliki keragaman jenis, sawi juga memiliki kandungan gizi yang cukup tinggi. Tanaman Sawi rasanya enak serta mempunyai kandungan gizi yang dibutuhkan tubuh manusia seperti energi, protein, lemak, karbohidrat, serat, fosfor, zat Besi, natrium, kalium, dan sumber vitamin A.

Menurut Direktorat Gizi Departemen Kesehatan Republik Indonesia, kandungan gizi tanaman sawi dalam 100 g bahan yang dapat dimakan mengandung energi 22,00 kalori, protein $2,30 \mathrm{~g}$, lemak 0,30 g, karbohidrat 4,00 g, serat $1,20 \mathrm{~g}$, kalsium $220,50 \mathrm{mg}$, fosfor $38,40 \mathrm{mg}$, zat besi $2,90 \mathrm{mg}$, vitamin A 969,00 SI, thiamine 0,09 $\mathrm{mg}$, riboflavin 0,10 mg, niacin 0,70 $\mathrm{mg}$, dan vitamin C 102,00 mg.

Tanaman sawi dapat dimanfaatkan baik setelah diolah maupun dimakan secara langsung sebagai lalapan. Selain memiliki kandungan vitamin dan zat gizi yang penting bagi kesehatan, sawi dipercaya dapat menghilangkan rasa gatal di tenggorokan saat terkena batuk. Menghilangkan pusing, pembersih darah, serta dapat membantu fungsi kerja ginjal. 


\section{Kangkung}

Kangkung tergolong sayuran yang sangat populer, karena banyak peminatnya. Kangkung disebut juga swamp cabbage, water convolvulus, water spinach, berasal dari India yang kemudian menyebar ke Malaysia, Burma, Indonesia, China Selatan Australia dan bagian negara Afrika. Taksonomi tanaman kangkung sebagai berikut:

$\begin{array}{ll}\text { Divisi } & \text { : Spermatophyta } \\ \text { Anak divisi } & \text { : Angiospermae } \\ \text { Kelas } & \text { : Dicotyledoneae } \\ \text { Bangsa } & \text { : Graniales } \\ \text { Suku } & \text { : Euphorbiaceae } \\ \text { Anak suku } & \text { : Phyllanthoideae } \\ & \text { : Phyllant } \\ \text { Marga } & \text { : Sauropus } \\ \text { Jenis } & \text { : Sauropus androgynus L. Merr }\end{array}$

Tanaman kangkung memiliki ciri-ciri morfologi sebagai berikut:

1. Akar

Kangkung memiliki perakaran tunggang dan cabang-cabangnya akar menyebar ke semua arah, dapat menembus tanah sampai kedalaman 60 hingga $100 \mathrm{~cm}$, dan melebar secara mendatar pada radius $150 \mathrm{~cm}$ atau lebih, terutama pada jenis kangkung air.

2. Batang

Batang kangkung bulat dan berlubang, berbukubuku, banyak mengandung air (herbaceous) dari buku-bukunya mudah keluar akar dan memiliki percabangan yang banyak dan setelah tumbuh lama batangnya akan menjalar. 
3. Daun

Bentuk daun umumnya runcing ataupun tumpul, permukaan daun sebelah atas berwarna hijau tua, dan permukaan daun bagian bawah berwarna hijau muda. Kangkung memiliki tangkai daun melekat pada buku-buku batang dan di ketiak daunnya terdapat mata tunas yang dapat tumbuh menjadi percabangan baru.

4. Bunga

Bunga kangkung umumnya berbentuk terompet dan daun mahkota bunga berwarna putih atau merah lembayung.

5. Buah

Buah kangkung berbentuk bulat telur yang didalamnya berisi tiga butir biji. Bentuk buah kangkung seperti melekat dengan bijinya. Warna buah hitam jika sudah tua dan hijau ketika muda. Buah kangkung berukuran kecil sekitar $10 \mathrm{~mm}$, dan umur buah kangkung tidak lama.

6. Biji

Bentuk biji kangkung bersegi-segi atau tegak bulat. Berwarna cokelat atau kehitam-hitaman, dan termasuk biji berkeping dua. Pada jenis kangkung darat biji kangkung berfungsi sebagai alat perbanyakan tanaman secara generatif.

Kangkung merupakan tanaman semusim atau tahunan yang merupakan sayuran daun yang penting di kawasan Asia Tenggara dan Asia Selatan. Sayuran kangkung mudah dibudidayakan, berumur pendek, dan harga relatif murah. Karena itu, kangkung merupakan sumber gizi yang baik bagi masyarakat secara umum. Konsumsi kangkung mulai digemari oleh masyarakat terbukti dengan sadarnya masyarakat peduli dengan gizi yang terkandung di sayuran 
kangkung. Kandungan gizi kangkung cukup tinggi terutama vitamin A, vitamin C, zat besi, kalsium, potasium, dan fosfor.

E. Daun kelor

Kelor (Moringa oleifera L.) merupakan tanaman yang mudah dijumpai di lingkungan sekitar dan tumbuh di daerah Jawa, Sunda, Bali, Lampung, Flores, Madura, dan Sulawesi. Kelor memiliki beberapa nama daerah seperti Pandan Rampe, Pandan Wangi (Jawa), SeukeBangu, Pandan Jau, Pandan Bebau, Pandan Rempai (Sumatera), Pondang, Pondan, Ponda, Pondago (Sulawesi), Kelamoni, Haomoni, Kekermoni, OrmonFoni, Pondak, Pondaki, Pudaka (Maluku), PandanArrum (Bali), Bonak (Nusa Tenggara). Kelor mempunyai taksonomi sebagai berikut:

$\begin{array}{ll}\text { Kingdom } & \text { : Plantae } \\ \text { Sub kingdom } & \text { : Tracheobionta } \\ \text { Divisi } & \text { : Magnolioophyta } \\ \text { Class } & \text { : Magnoliosida } \\ \text { Sub class } & \text { : Dilleniidae } \\ \text { Ordo } & \text { : Capparales } \\ \text { Family } & \text { : Moringaceae } \\ \text { Genus } & \text { : Moringa } \\ \text { Species } & \text { : Moringa oleifera Lamk. }\end{array}$

Kelor memiliki nutrisi yang tinggi karena daunnya mengandung vitamin A yang setara dengan 10 kali vitamin A yang terdapat pada wortel, setara dengan 17 kali kalsium yang terdapat pada susu, setara dengan 15 kali kalsium pada pisang, setara dengan 9 kali protein yang terdapat pada yoghurt dan setara 25 kali zat besi pada bayam.

Salah satu tanaman yang banyak mengandung antioksidan ditemukan dalam daun kelor. Selain itu daun 
kelor juga kaya akan phytochemicals, karoten, vitamin, mineral, asam amino, senyawa flavonoid, dan phenolic.

Tanaman kelor memiliki beberapa khasiat dan merupakan tanaman paling kaya nutrisi yang ditemukan untuk saat ini. Kelor mengandung lebih banyak vitamin, mineral, antioksidan, asam amino esensial, dan senyawa lain yang bermanfaat bagi tubuh.

\section{F. Kubis}

Kubis atau kol sebenarnya merupakan tanaman semusim atau lebih yang berbentuk perdu. Tanaman kubis berbentuk perdu berbatang pendek dan beruas-ruas, sebagai bekas tempat duduk daun. Tanaman ini berakar tunggang dengan akar sampingnya sedikit tetapi dangkal. Daunnya lebar berbentuk bulat telur dan lunak. Bunganya tersusun dalam tandan dengan mahkota bunga berwarna kuning spesifik. Buahnya bulat panjang menyerupai polong. Polong muda berwarna kecoklatan dan mudah pecah. Bijinya kecil, berbentuk bulat dan berwarna kecoklatan. Biji yang banyak tersebut menempel pada dinding bilik tengah polong.

Tanaman kubis mempunyai taksonomi sebagai berikut:

$\begin{array}{ll}\text { Kingdom } & \text { : Plantae } \\ \text { Divisi } & \text { : Magnoliophyta } \\ \text { Kelas } & \text { : Magnoliopsida } \\ \text { Ordo } & \text { : Brassicales } \\ \text { Famili } & \text { : Brassicaceae } \\ \text { Genus } & \text { : Brassica } \\ \text { Spesies } & \text { : Brassica oleraceae }\end{array}$

Kepala kubis paling tepat digambarkan sebagai tunas akhir tunggal yang besar, terdiri dari daun yang saling 
bertumpang tindih secara ketat, serta menempel dan melingkupi batang pendek tidak bercabang. Tinggi tanaman umumnya berkisar antara 40 hingga $60 \mathrm{~cm}$.

Pada sebagaian kultivar, pertumbuhan daun awal memanjang dan tiarap. Daun berikutnya secara progresif lebih pendek, lebih lebar, lebih tegak dan mulai menindihi daun yang lebih muda. Pembentukan daun terus berlangsung dan pertumbuhan daun terbawah dari daun yang saling bertumpang tindih meningkatkan kepadatan kepala yang berkembang.

Bersamaan dengan pertumbuhan daun, batang juga lambat laun memanjang dan membesar. Pertumbuhan kepala bagian dalam yang terus berlangsung hingga melewati fase matang (keras) dapat menyebabkan pecahnya kepala. Variabel komoditas yang penting adalah ukuran kepala, kerapatan, bentuk, warna, tekstur daun, dan periode kematangan.

Bentuk kepala berkisar dari elips meruncing hingga gepeng lirdu, dengan bentuk yang paling disukai adalah bundar atau hampir bundar. Warna daun dengan atau tanpa lapisan lilin, beragam dari hijau muda hingga hijau-biru tua dan juga ungu kemerahan. Tektur daun licin atau kusut.

Kubis termasuk sayuran yang kaya akan vitamin B dan C serta mineral berupa kalsium dan fosfor. Kubis juga mengandung senyawa fenol dan flavonoid yang berperan sebagai antioksidan dan aktivitas antioksidan pada kubis hijau sedikit lebih rendah dibandingkan kubis merah.

\section{G. Daun singkong}

Singkong (Manihot utilissima) merupakan tanaman pangan berupa perdu dengan nama lain ubi kayu atau 
kasape. Tanaman singkong merupakan perdu tidak bercabang atau bercabang sedikit, tinggi 2- 7 meter, batang dengan tanda bekas daun yang bertonjolan. Umbi akar besar, memanjang, dengan kulit berwarna coklat suram. Di Indonesia, tanaman singkong ditanam sebagai tanaman pangan dan dapat hidup pada ketinggian 5-1.300 mdpl.

Daun singkong memiliki tangkai daun dengan panjang 6-35 cm, helaian daun sampai dengan pangkal berbagi menjadi 3-9. Daun singkong memiliki kandungan gizi tinggi, diantaranya flavonoid dan saponin. Daun singkong memiliki banyak manfaat di dunia kesehatan karena memiliki kandungan vitamin C yang cukup tinggi (sekitar 27,5\%), senyawa organik flavonoid, triterpenoid, tanin, serta saponin. Konsumsi vitamin $\mathrm{C}$ sangat bermanfaat dalam proses penyembuhan luka karena dapat mempengaruhi tingkat keparahan respon inflamasi dan kualitas penyembuhan. Flavonoid dan saponin sejak lama diketahui memiliki aktivitas antimikroba dan antivirus. Demikian juga triterpenoid yang sering ditemukan pada banyak tanaman obat dan diketahui memiliki aktivitas antivirus dan antibakteri, serta dapat mengobati kerusakan pada kulit.

\section{H. Brokoli}

Brokoli (Brassica oleracea L. kelompok Italica) adalah tanaman sayuran yang termasuk dalam suku kubis-kubisan atau Brassicaceae. Brokoli berasal dari daerah Laut Tengah dan sudah sejak masa Yunani Kuno dibudidayakan. Sayuran ini masuk ke Indonesia belum lama (sekitar 1970- an) dan kini cukup populer sebagai bahan pangan. Klasifikasi tanaman brokoli adalah sebagai berikut:

Divisi : Spermatophyta

Subdivisi : Angiospermae 
Kelas : Dicotyledoneae

Famili : Cruciferae

Genus : Brassica

Spesies : Brassica oleraceae L.

Terdapat tiga jenis brokoli yang dikembangkan diseluruh dunia, yaitu:

1. Brokoli Italia hijau yang banyak ditemui dipasar dengan daun yang besar dan batang yang tebal.

2. Brokoli Romanesco yang berwarna hijau kekuningan dan bentuk daunnya yang menonjol.

3. Brokoli yang berwarna ungu dan memiliki daun seperti kembang kol namun lebih kecil. Brokoli jenis ini biasanya dijual di Spanyol, Italia, dan Inggris.

Tanaman brokoli memiliki ciri-ciri morfologi sebagai berikut:

1. Akar

Brokoli memiliki akar serabut dan akar tunggang. Akar tunggang tumbuh ke pusat bumi, sedangkan akar serabut tumbuh kearah samping, melebar dan dangkal $(20--0 \mathrm{~cm})$. Sistem perakaran yang dangkal membuat tanaman ini dapat tumbuh dengan baik apabila ditanam pada tanah yang gembur dan porous.

2. Batang

Batang tumbuh tegak dan pendek $( \pm 30 \mathrm{~cm})$, berwarna hijau, tebal, lunak namun cukup kuat dan bercabang samping. Batang halus tidak berambut, dan tidak begitu tampak jelas karena tertutup oleh daun daun. 
3. Daun

Daun berbentuk bulat telur (oval) dengan tepi daun bergerigi agak panjang dan membentuk celah-celah yang menyirip agak melengkung kedalam. Daun berwarna hijau dan tumbuh berselang-seling pada batang tanaman, tangkainya agak panjang dengan pangkal daun yang tebal dan lunak. Daun-daun yang tumbuh pada pucuk batang sebelum masa bunga terbentuk, berukuran kecil dan melengkung ke dalam melindungi bunga yang sedang mulai tumbuh.

4. Bunga

Bunga brokoli merupakan kumpulan masa bunga yang berjumlah lebih dari 5.000 kuntum bunga bersatu membentuk bulatan tebal serta padat (kompak). Warna bunga sesuai dengan varietasnya, ada yang memiliki masa bunga hijau muda, hijau tua, hijau kebiru-biruan (ungu). Berat berkisar 0,6-0,8 kg dengan diameter antara 18-25 $\mathrm{cm}$, tergantung varietasnya. Pada kondisi lingkungan yang sesuai, bunga brokoli dapat tumbuh memanjang menjadi tangkai bunga yang penuh dengan kuntum bunga. Tiap bunga terdiri atas empat helai daun kelopak (calyx), empat helai daun mahkota (corolla), enam benang sari yang komposisinya empat memanjang dan dua pendek.

5. Buah

Buahnya terbentuk dari hasil penyerbukan bunga yang terjadi karena penyerbukan sendiri ataupun penyerbukan silang dengan bantuan serangga lebah madu. Buah berbentuk polong, berukuran 
kecil dan ramping dengan panjang antara 3-5 cm. Bakal buah terbagi menjadi dua ruang, dan setiap ruang berisi bakal biji.

6. Biji

Didalam buah tersebut terdapat biji berbentuk bulat kecil, berwarna coklat kehitam-hitaman. Biji-biji tersebut dapat dipergunakan sebagai benih perbanyakan tanaman.

Brokoli mempunyai aktivitas antihiperglikemik. Selain itu, brokoli termasuk sayuran dengan indeks glikemik yang rendah, yaitu 15. Brokoli kaya akan mineral seperti kalsium, magnesium, kalium, besi, dan zinc, serta folat dan serat. Brokoli juga kaya akan antioksidan (vitamin C dan vitamin E) serta fitokimia, karoteoid, klorofil, sulforafan, isotiosianat, dan glukosinolat. Kadar serat dalam brokoli sebesar 3,3 g / $100 \mathrm{~g}$, lebih tinggi dibandingkan wortel, selada, dan jagung.

Setangkai brokoli berukuran medium memberikan kontribusi vitamin C setara 220 persen AKG (Angka Kecukupan Gizi) dan vitamin A 15 persen AKG. Kelebihan vitamin $C$ di dalam tubuh akan dibuang, karena menurut AKG vitamin $C$ yang dibutuhkan tubuh sebanyak $60 \mathrm{mg}$. Tetapi ini mungkin masih belum cukup melindungi diri dari tinggi nya kolesterol. Suplemen vitamin C sebesar $500 \mathrm{mg}$ menurut penelitian tidak memberikan efek samping berarti bagi tubuh. Konsumsi 220 AKG masih dapat diterima oleh tubuh.

Asam folat yang terkandung didalam brokoli apabila dilakukan proses perebusan akan menghilangkan sekitar 50 $\%$ asam folat. Pengolahan brokoli dengan cara direbus sebaiknya tidak terlalu lama maksimal sekitar 5 menit. Brokoli mengandung vitamin $\mathrm{C}$ dan serat makanan dalam jumlah banyak. Brokoli juga mengandung senyawa glukorafanin, yang merupakan bentuk alami senyawa 
antikanker sulforafana (sulforaphane) dan senyawa istiosianat yang memiliki aktivitas antikanker. Brokoli juga berguna untuk mencegah kanker payudara, sehingga baik untuk wanita mengonsumsi brokoli. Indole pada brokoli meningkatkan ekskresi yang diikat pada kanker payudara. Selain kanker payudara, mengonsumsi brokoli juga dapat menurunkan risiko kanker rahim.

Manfaat dari brokoli secara garis besar dapat meningkatkan daya kerja otak, mengatur tingkat gula darah, menetralkan zat penyebab kanker, menurunkan kolesterol jahat, bagi wanita hamil baik dikonsumsi karena mengandung asam folat, dan karena mengandung vitamin $\mathrm{C}$ juga berperan sebagai antioksidan.

\section{Selada}

Selada, atau dikenal dengan sebutan selada keriting (Lactuca sativa L.) adalah tanaman asli lembah Mediterania Timur. Terdapat bukti berupa lukisan pada kuburan Mesir kuno yang menunjukkan bahwa Lactuca sativa L. telah ditanam sejak tahun 4500 SM. Tanaman ini awalnya digunakan sebagai obat dan pembuatan minyak, selain itu biji selada juga dapat dimakan. Selada keriting mempunyai taksonomi sebagai berikut:

$\begin{array}{ll}\text { Phylum } & \text { : Spermatophyta } \\ \text { Ordo } & \text { : Dicotyledoneae } \\ \text { Subclass } & \text { : Angiospermae } \\ \text { Super famili } & \text { : Asterales } \\ \text { Genus } & \text { : Lactuca } \\ \text { Species } & \text { : Lactuca sativa L. }\end{array}$


Tanaman selada memiliki ciri-ciri morfologi sebagai berikut:

1. Daun

Selada daun adalah tanaman semusim (annual) dan polimorf khususnya pada bagian daun selada. Kultivar selada daun sangat beragam ukuran, warna dan tekstur daunnya. Daun selada keriting memiliki bentuk tangkai daun lebar dan tulang daun menyirip. Tekstur daun lunak, renyah dan terasa agak manis. Daun selada keriting memiliki ukuran panjang 20 hingga 25 $\mathrm{cm}$ dan lebar sekitar $15 \mathrm{~cm}$.

2. Batang

Batang tanaman selada keriting termasuk batang sejati, bersifat kekar, kokoh, dan berbuku - buku, ukuran diameter batang berkisar antara $2-3 \mathrm{~cm}$.

3. Akar

Tanaman ini menghasilkan akar tunggang dengan cepat dengan dibarengi dengan berkembang dan menebalnya akar lateral secara horizontal. Akar lateral tumbuh didekat permukaan tanah berfungsi untuk menyerap sebagian air dan hara.

4. Bunga

Perbungaan selada keriting memiliki tipe mulai rata padat yang tersusun dari banyak bongkol bunga yang terdiri dari 10 - 25 kuncup bunga dengan melakukan penyerbukan sendiri meskipun terkadang penyerbukan dibantu dengan serangga. Seluruh bunga dalam bongkol yang sama akan membuka secara bersamaan dan singkat pada pagi hari. 


\section{Biji}

Biji di dalam bongkol bunga yang sama juga berkembang secara bersamaan, setiap satu bunga menghasilkan satu biji yang disebut achene. Biji cenderung tersebar, berukuran kecil, bertulang dan diselubungi rambut kaku.

Daun tanaman selada keriting mengandung vitamin A, B, dan C yang bermanfaat bagi kesehatan. Selada keriting memiliki banyak kandungan gizi dan mineral. Selada memiliki nilai kalori yang sangat rendah. Selada keriting kaya akan vitamin $\mathrm{A}$ dan $\mathrm{C}$ yang baik untuk menjaga fungsi penglihatan dan pertumbuhan tulang normal. Selada memiliki manfaat lain dapat memperbaiki organ dalam, mencegah panas dalam, melancarkan metabolisme, membantu menjaga kesehatan rambut, mencegah kulit menjadi kering, dan dapat mengobati insomia. Kandungan gizi yang terdapat pada selada adalah serat, provitamin A (karotenoid), kalium, dan kalsium.

Kandungan gizi selada keriting dalam tiap $100 \mathrm{~g}$ adalah kalori $15,00 \mathrm{kal}$, protein $1,20 \mathrm{~g}$, lemak 0,20 g, karbohidrat 2,90 g, kalsium 22,00 mg, fosfor 25,00 mg, zat besi (Fe) 0,50 mg, vitamin A 540,00 S.I, vitamin B1 0,04 mg, Vitamin C 8,00 mg, dan air 94,8 g.

\section{J. Semanggi}

Semanggi (Marsilea crenata) merupakan salah satu jenis tumbuhan air, sehingga sering disebut semanggi air. Klasifikasi tanaman semanggi adalah sebagai berikut:

$\begin{array}{ll}\text { Kingdom } & \text { : Plantae } \\ \text { Sub kingdom } & \text { : Tracheobionta } \\ \text { Divisi } & \text { : Pteridophyta } \\ \text { Kelas } & \text { : Pteriopsida }\end{array}$




$\begin{array}{ll}\text { Ordo } & : \text { Marsialeales } \\ \text { Famili } & : \text { Marsileaceae } \\ \text { Genus } & : \text { Marsilea } \\ \text { Spesies } & : \text { Marsilea crenata Presl. }\end{array}$

Daun semanggi adalah daun majemuk dengan empat daun, tangkai daun bundar dan berbulu halus di permukaan. Kandungan mineral pada daun dan tangkai semanggi air adalah kalium, fosfor, besi, natrium, kalsium, seng, dan tembaga. Semanggi air juga memiliki kandungan fitokimia seperti alkaloid, steroid, flavonoid, karbohidrat, gula pereduksi, dan asam amino.

Kandungan mineral dan fitokimia (kalium dan flavonoid) dalam semanggi berfungsi untuk melarutkan kristal kalsium oksalat dalam saluran kemih. Selain itu, semanggi juga memiliki efek antioksidan, antiinflamasi, analigesik, demam, ekspektoran, dan terapi untuk penyakit hepar.

\section{K. Seledri}

Seledri (Apium graveolens L.) merupakan sayuran daun yang memiliki tinggi maksimal 1 meter. Seledri adalah tanaman yang digunakan untuk bumbu masakan, tanaman hijau ini termasuk tanaman yang mudah ditanam, baik dataran tinggi maupun dataran rendah antara $0-1.200$ meter, tanaman seledri tidak tahan terkena hujan lebat dan harus terlindung dari terpaan air hujan. Seledri mempunyai taksonomi sebagai berikut:

$\begin{array}{ll}\text { Kingdom } & \text { : Plantae } \\ \text { Divisi } & \text { : Spermatophyta } \\ \text { Sub divisi } & \text { : Angiospermae } \\ \text { Ordo } & \text { : Umbelliferales } \\ \text { Famili } & \text { : Umbelliferae (apiaceace) }\end{array}$


Genus : Apium

Spesies

: Apium graveolens L.

Tanaman seledri memiliki ciri-ciri morfologi sebagai berikut:

1. Akar

Perakaran tanaman seledri menyebar ke samping panjangnya sampai kedalaman $30 \mathrm{~cm}$.

2. Batang

Batang atau sering disebut juga tangkai tanaman seledri berwarna hijau dan pendek.

3. Daun

Daun seledri memiliki warna hijau dan memiliki aroma harum.

Dalam $100 \mathrm{~g}$ daun seledri segar mengandung energi 20 kalori, protein $1,0 \mathrm{~g}$, lemak $0,1 \mathrm{~g}$, karbohidrat 4,6 g, kalsium $50 \mathrm{mg}$, fosfor $40 \mathrm{mg}$, besi 1,00 mg, vitamin A 0,03 S.I, vitamin C $11 \mathrm{mg}$, dan air 93 gram.

Kandungan gizi pada sayuran seledri akan memberikan nutrisi bagi kesehatan tubuh, menurunkan tekanan darah tinggi, memperlebar pembuluh darah, meningkatkan nafsu makan dan lain-lain.

\section{Daun Kemangi}

Daun kemangi (Ocimum sanctum L.) memiliki beberapa nama daerah seperti Kemangi, kemangen (Indonesia, Jawa), Kamangi (Makassar), Lampes (Jawa Tengah), Uku-Uku (Bali), Lufe-Lufe (Ternate), Suraung (Sunda), dan Kemanghi (Madura). Klasifikasi tanaman kemangi sebagai berikut:

$\begin{array}{ll}\text { Kingdom } & \text { : Plantae } \\ \text { Sub kingdom } & \text { : Tracheobionta }\end{array}$ 


$\begin{array}{ll}\text { Divisi } & \text { : Magnoliophyta } \\ \text { Sub Divisi } & \text { : Spermatophyta } \\ \text { Kelas } & \text { : Magnoliopsida } \\ \text { Sub kelas } & \text { : Asteridae } \\ \text { Ordo } & \text { : Lamiales } \\ \text { Family } & \text { : Lamiaceae } \\ \text { Genus } & \text { : Ocimum } \\ \text { Spesies } & \text { : Ocimum sanctum L. }\end{array}$

Kemangi merupakan tanaman semak perdu dan berpenampilan cukup rimbun. Tanaman ini tumbuh tegak hingga tingginya mencapai 0,3-1,5 m. Tanaman kemangi memiliki ciri-ciri morfologi sebagai berikut:

1. Akar

Akarnya tunggang, Akar pada tanaman kemangi hutan terdiri dari bulu akar untuk menyerap air juga unsur hara dalam tanah dan tudung akar untuk melindungi ujung akar yang akan merambat. Akar tanaman berwarna putih kotor dengan sistem perakaran tanaman kemangi menyebar ke segala arah.

2. Batang

Batang berkayu, berbentuk segi empat, berbukubuku, dan beralur. Bercabang banyak di bagian atas, berbulu, dan berwarna hijau tua atau hijau keunguan. Batang muda berwarna hijau muda, ungu muda atau ungu tua namun setelah tua berubah menjadi kecoklat-coklatan. Batang mencapai ketinggian $30-150 \mathrm{~cm}$. Pada tiap buku batang dan cabang melekat daun secara berhadap-hadapan. 
3. Bunga

Bunga tumbuh dari ujung batang, cabang, dan ranting. Bunga berukuran kecil dan berwarna putih, tersususun dalam karangan bunga (inforescentia). Setiap karangan bunga terdiri atas 1-6 cabang tandan yang terkumpul menjadi tandan. Karangan bunga panjang $15 \mathrm{~cm}$ sebagai tempat melekat 10-20 kelompok bunga. Bunga kemangi termasuk bunga semu yang mempunyai struktur terdiri atas daun pelindung bunga, kelopak bunga, mahkota bunga, putik dan benang sari. Daun pelindung bunga berbentuk elips (bulat telur) panjang 0,5 sampai $1 \mathrm{~cm}$. Kelopak bunga berwarna hijau atau ungu, tidak berambut, sebelah dalam lebih rapat, dan bergerigi secara tidak teratur. Mahkota bunga berwarna putih atau putih kemerah-merahan, tangkai kepala putik berwarna putih atau ungu sedangkan tangkai benang sari dan tepung sari berwarna putih atau kuning.

4. Daun

Daunnya tunggal dan berwarana hijau, bersilang, dengan tangkai daun $0,5-2 \mathrm{~cm}$, helaian daun bulat telur ellips, ujungnya runcing, berbintik-bintik serupa kelenjar, pangkal tumpul, tepi bergerigi, dan pertulangan daun menyirip, Panjang 14-16 $\mathrm{mm}$, lebar 3-6 mm, tangkai $1 \mathrm{~cm}$.

5. Biji

Biji ukurannya kecil, keras, dan berbentuk bulat telur atau bulat panjang dengan diameter $1 \mathrm{~mm}$. Biji muda berwarna putih, setelah tua berwarna coklat atau hitam. Apabila biji di masukan dalam air akan mengembang. 


\section{Buah}

Buah berbentuk kotak, berwarna cokelat tua, tegak, dan tertekan dengan ujung berbentuk kait melingkar. Panjang kelopak buah 6-9 mm. Biji berukuran kecil, bertipe keras, cokelat, dan waktu diambil segera membengkak. Tipe buah terdiri dari empat biji. Akar tunggang dan berwarna putih kotor.

Secara tradisional tanaman kemangi digunakan sebagai obat sakit perut, obat demam, menghilangkan bau mulut, dan sebagai sayuran. Kemangi mengandung tannin, flavonoid, alkaloid, terpenoid, saponin, glikosida, asam amino primer, dan sekunder. Daun kemangi berkhasiat sebagai analgesik, anti-amnesik, dan nootropik, anthelmintik, anti bakterial, anti katarak, anti fertilitas, anti hiperlipidemi, anti inflamasi, anti malaria, anti lipidperoksidatif, anti oksidan, anti stress, anti thyroid, antitusif, anti ulkus, kemoprotektif, penyakit kulit, penyakit diabetes, imunomodulator, radioprotektif, aktivitas hipoglikemik, aktivitas hipotensif, dan anti kanker.

\section{Ringkasan}

Beberapa jenis, morfologi dan manfaat sayuran daun yang telah dibahas pada bab ini antara lain bayam, daun katuk, sawi, kangkung, daun kelor, daun singkong, kubis, brokoli, selada, semanggi, seledri dan daun kemangi.

N. Latihan Soal

\section{Tugas Individu}

Carilah jurnal tentang pengolahan sayuran daun dari beberapa jenis sayuran daun yang sudah disebutkan pada 
bab ini. Tulis literatur dan cara pembuatannya serta buat diagram alir proses pembuatannya!

\section{Tugas Kelompok}

Eksplorasi jenis sayuran daun yang belum dicantumkan pada bab ini, jelaskan morfologi, manfaat dan jenis olahannya!

\section{Daftar Pustaka}

Azeliya, R. M. 2013. Pembuatan Bolu Brokoli (Brassica oleracea L) Dilihat dari Kadar Beta Karoten dan Kadar Vitamin C Serta Daya Terima. Naskah Publikasi. Universitas Muhammadiyah Surakarta. Surakarta.

Haerani, T. 2016. Pengaruh Penggunaan Berbagai Jenis Lampu terhadap Pertumbuhan Bayam (Amaranthus sp). Skripsi. Universitas Islam Negeri Alauddin Makassar. Makassar.

Handayani, L. 2014. Indeks Glikemik dan Beban Glikemik Vegetable Leather Brokoli (Brassica oleracea var. Italica) dengan Substitusi Inulin. Artikel Penelitian. Universitas Diponegoro. Semarang.

Hidayat, T. 2019. Respon Tanaman Kangkung Darat (Ipomea reptans Poir.) terhadap Konsentrasi Pupuk Organik Cair NASA. Skripsi. Universitas Andalas. Padang.

Iwantari, A. 2012. Skripsi. Pengaruh Pemberian Biofertilizer dan Jenis Media Tanam terhadap Pertumbuhan da $\mathrm{n}$ Produktivitas Tanaman Kubis (Brassica oleracea). Universitas Airlangga. Surabaya. 
Lubis, J. 2018. Pengaruh Pertumbuhan dan Produksi Tanaman Selada (Lactuca sativa L.) pada Sistem Hidroponik NFT dengan Berbagai Konsentrasi Pupuk AB Mix dan Bayfolan. Skripsi. Universitas medan Area. Medan.

Lukman, A. 2016. Uji Aktivitas Antibakteri Ekstrak Daun Kemangi (Ocimum sanctum L) Terhadap Bakteri Patogen Dengan Metode KLT Bioautografi. Skripsi. Universitas Islam Negeri Alauddin Makassar. Makassar.

Nurhidayah, L. 2018. Perbedaan Pertumbuhan Tanaman Sawi Hijau (Brassica juncea L.) pada Media Tanam Hidroponik dan Media Tanah. Skripsi. Universitas Ialam Negeri Mataram. Mataram.

Puspitarini, B. A. 2010. Uji Aktivitas Antioksidan Ekstrak Daun Singkong (Manihotis folium) menggunakan Metode Diphenylpicryl Hydrazyl (DPPH). Skripsi. Universitas Sanata Dharma. Yogyakarta.

Sangaji, Z. 2017. Kajian Sistem Budidaya Tanaman Sawi (Brassica juncea L ) Di Petani Kelurahan Malawele Distrik Aimas Kabupaten Sorong. Jurnal Median 9 (1): 16-24.

Sari, A. N. 2018. Efektivitas Daun Kemangi (Ocimum sanctum L.) Sebagai Ovisida Terhadap Nyamuk Aedes aegypti (Sebagai Bahan Penuntun Praktikum Biologi Materi Pencemaran Lingkungan pada Peserta Didik SMA Kelas X Semester Genap). Skripsi. Universitas Islam Negeri Raden Intan Lampung. Lampung.

Yulis, S. 2015. Formulasi Ekstrak Etanol Daun Kelor (Moringa oleifera L.) Pada Sediaan Krim Wajah Terhadap 
Bakteri Staphylococcus epidermidis. Skripsi. Institut Kesehatan Helvetia. Medan. 
BAB III

\section{KUALITAS BAHAN DAN KEHILANGAN PASCA PANEN}

Karakteristik penting komoditas sayur pasca panen adalah bahan tersebut masih hidup dan masih melakukan aktifitas metabolismenya. Akan tetapi metabolisme tidak sama dengan tanaman induknya yang tumbuh dengan lingkungan aslinya, karena produk yang telah dipanen mengalami berbagai bentuk stress seperti hilangnya suplai nutrisi, kondisi yang berbeda dengan pertumbuhannya yang ideal dengan adanya peningkatan suhu, dan kelembaban. Selain itu proses panen sering kali menimbulkan pelukaan serta pengemasan dan transportasi yang dapat menimbulkan kerusakan mekanis lebih lanjut.

Aktivitas metabolisme pada sayuran segar dicirikan dengan adanya proses respirasi. Respirasi menghasilkan panas yang menyebabkan terjadinya peningkatan panas pada produk itu sendiri, sehingga proses kemunduran seperti kehilangan air, pelayuan, dan pertumbuhan mikroorganisme akan semakin meningkat. Mikroorganisme pembusuk akan mendapatkan kondisi pertumbuhan yang ideal dan siap menginfeksi sayuran melalui pelukaan-pelukaan yang sudah ada. Selama transportasi ke konsumen, produk sayuran pasca panen mengalami tekanan fisik, getaran, gesekan pada kondisi dimana suhu dan kelembaban memacu proses pelayuan.

Respirasi memproduksi panas. Setiap gram berat molekul glukosa yang direspirasikan menghasilkan 673 joules energi panas. Panas yang dihasilkan ini menyebabkan masalah selama pendistribusian produk. Awal peningkatan respirasi sejalan atau linier dengan peningkatan suhu (mulai dari $0^{\circ} \mathrm{C}$ ). Ini menunjukkan peningkatan laju respirasi yang 
signifikan sejalan dengan meningkatnya suhu. Setiap peningkatan suhu $10{ }^{\circ} \mathrm{C}$, laju respirasi secara kasar meningkat 2 - 3 kali. Jika suhu meningkat di atas $30{ }^{\circ} \mathrm{C}$, grafik menjadi mendatar, memperlihatkan peningkatan laju respirasi yang kecil. Jika produk diekspos pada suhu sekitar $45^{\circ} \mathrm{C}$ atau lebih tinggi, produk mulai mati dan respirasi mulai terhenti atau menurun cepat menuju kematian.

\section{A. Faktor Kualitas}

Definisi konvensional dari kualitas adalah menggambarkan karakteristik langsung dari suatu produk seperti performansi (performance), keandalan (reliability), mudah dalam penggunaan (easy of use), dan estetika (esthetics). Dalam pasar global dengan tingkat persaingan yang semakin tinggi, kualitas didefinisikan secara strategik sebagai sesuatu yang mampu memenuhi keinginan atau kebutuhan konsumen (meeting the needs of customers). Berdasarkan konsepsi diatas, pada hakikatnya kualitas merujuk kepada pengertian pokok seperti:

1. Kualitas terdiri dari sederet keistimewaan produk, baik keistimewaan langsung maupun keistimewaan atraktif yang memenuhi keinginan konsumen sehingga memberikan kepuasan atas penggunaan produk tersebut.

2. Kualitas terdiri dari segala sesuatu yang terbebas dari kekurangan atau kerusakan.

Mutu atau kualitas menjadi sangat penting untuk dapat mencitrakan produk tersebut seperti yang diinginkan oleh konsumen. Mutu dari produk yang akan dijual sangat tergantung pada kondisi produk tersebut saat penerimaan dan pengelolaan pascapanennya di pusat-pusat penjualan ritel. 
Kualitas sayuran daun yang paling umum dijelaskan berdasarkan kesegaran, kebersihan, dan kecerahan warna daunnya. Kesegaran sayuran daun berbanding lurus dengan kandungan airnya. Kehilangan air dapat berakibat terhadap kehilangan secara kualitatif dan kuantitatif dari produk. Mengurangi kenampakan karena pelayuan dan pengkerutan, mengurangi sukulensi karena turgiditas menurun, berkurangnya kerenyahan dan hilangnya juiceness, semuanya adalah kehilangan kualitatif. Untuk produk-produk yang dijual berdasarkan berat, maka kehilangan air adalah bersifat kuantitatif. Sekitar 5\% kehilangan berat dibutuhkan untuk mengurangi potensi pasar dari sayuran berdaun.

Warna daun pada sayuran merupakan parameter utama yang berpengaruh pada penerimaan konsumen. Secara umum, sayuran daun memiliki warna hijau segar hingga hijau pucat. Pigmen hijau pada sayuran daun mengindikasikan kandungan klorofil didalamnya. Klorofil merupakan senyawa bioaktif yang berperan penting pada proses fotosintesis pada tanaman, sedangkan manfaat klorofil bagi tubuh antara lain adalah sebagai antioksidan dan antimutagenik. Sayuran daun yang memiliki warna kuning lebih dari $10 \%$, meskipun masih dapat dikonsumsi namun sudah tidak layak dipasarkan lagi karena sudah tidak segar lagi.

Beberapa alternatif penyimpanan sayuran daun
untuk memperpanjang kesegarannya antara lain
penyimpanan pada suhu rendah, pengkabutan disekitar
sayuran, dan perendaman. Daun kemangi dapat bertahan
sampai tiga hari pada penyimpanan suhu $20^{\circ} \mathrm{C}$, sedangkan
selada dapat bertahan hingga tiga hari pada suhu
penyimpanan $15{ }^{\circ} \mathrm{C}$. Sedangkan perendaman sayuran
(crisping) sebelum pemajangan mampu memberikan efek


penyegaran sampai dua hari pemajangan pada suhu $10{ }^{\circ} \mathrm{C} \pm$ $2^{\circ} \mathrm{C}$.

Pengkabutan bertujuan untuk mempertahankan kelembaban relatif $(\mathrm{RH})$ di sekitar sayuran agar tetap tinggi sehingga laju transpirasi terhambat. $\mathrm{RH}$ pemajangan yang tinggi hanya dapat memperlambat transpirasi tetapi tidak menghentikannya. Oleh karenanya cadangan air dalam sayuran menurun atau berkurang yang menyebabkan terjadinya pelayuan.

Selain itu teknik pemajangan sayuran daun juga dapat diterapkan untuk mempertahankan kesegaran selama penjualan. Teknik pemajangan dengan metode perendaman pada bagian akar sayuran dapat menghambat proses pelayuan. Sayuran yang dipajang dengan metode perendaman akar dengan air lebih cepat mengalami proses penguningan dari pada proses pelayuan. Metode perendaman teraerasi pada suhu rata-rata $29^{\circ} \mathrm{C}$ dan $\mathrm{RH}$ ratarata $80 \%$ dapat mempertahankan warna daun menguning lebih dari $10 \%$ sampai pada hari ke-5 untuk kangkung dan hari ke-4 pada sawi dari budidaya hidroponik, sedangkan kangkung dan sawi pada teknik budidaya konvensional (ditanam di tanah) yang dipajang dengan metode perendaman teraerasi masing-masing memiliki ketahanan selama 2 hari.

Kualitas suatu produk sayuran sangat erat kaitannya dengan kepuasan konsumen karena akan berimbas langsung pada keputusan konsumen untuk membeli produk tersebut. Berdasarkan hasil brainstorming dan wawancara yang mengacu pada pengembangan karakteristik dan kualitas sayuran, diperoleh tujuh atribut untuk mengidentifikasikan kebutuhan konsumen. Ketujuh kualitas tersebut antara lain 
kesegaran, ukuran, warna, kebersihan, daya tahan, bentuk yang standar, dan keamanan produk.

Terdapat hubungan keterkaitan antara kualitas mutu dengan parameter penanganan teknis selama pemanenan (Tabel 1). Pembersihan dan sortasi berpengaruh kuat terhadap kebersihan sayuran karena pada tahap pembersihan dilakukan pembersihan sayuran dari tanah, rumput, dan ranting. Selanjutnya dilakukan pencucian dengan air mengalir, kemudian ditiriskan. Pada sortasi dilakukan pemilahan antara sayuran yang rusak dan kotor dengan yang baik dan bersih.

Tabel 1. Hubungan Kualitas Mutu dengan Parameter Teknis

\begin{tabular}{|c|c|c|c|c|c|c|c|c|}
\hline \multirow[b]{2}{*}{$\begin{array}{l}\text { Kualitas } \\
\text { mutu } \\
\text { sayuran }\end{array}$} & \multicolumn{8}{|c|}{ Parameter teknis } \\
\hline & $\begin{array}{l}\frac{c}{\sigma} \\
\frac{c}{Q} \\
\frac{c}{\sigma} \\
\frac{\varepsilon}{Q} \\
0\end{array}$ & 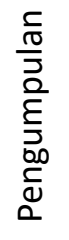 & 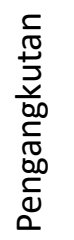 & 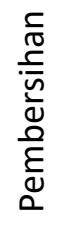 & 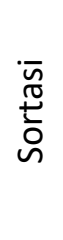 & 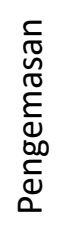 & 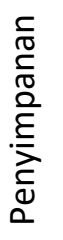 & 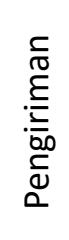 \\
\hline Kebersihan & ++ & + & + & +++ & +++ & ++ & ++ & ++ \\
\hline Kesegaran & +++ & +++ & +++ & ++ & ++ & +++ & +++ & +++ \\
\hline Keamanan & ++ & ++ & ++ & +++ & ++ & +++ & +++ & + \\
\hline Daya tahan & +++ & ++ & ++ & +++ & + & +++ & +++ & ++ \\
\hline Warna & +++ & ++ & ++ & +++ & ++ & +++ & +++ & ++ \\
\hline Ukuran & + & + & + & + & +++ & + & ++ & + \\
\hline Bentuk & +++ & ++ & ++ & + & +++ & + & ++ & ++ \\
\hline
\end{tabular}

Keterangan: +: hubungan lemah; ++: hubungan sedang; +++: hubungan kuat. 
Pemanenan, pengumpulan, pengangkutan, pengemasan, penyimpanan, dan pengiriman berpengaruh kuat terhadap kesegaran sayuran. Pemanenan dilakukan pagi hari sebelumnya untuk menghindari panas sinar matahari. Pengumpulan dan pengangkutan sayuran dilakukan di tempat teduh dan segera diangkut ke ruang produksi. Untuk menjaga kesegaran, produk dikemas dan disimpan di ruang pendingin dengan suhu 5 sampai $7{ }^{\circ} \mathrm{C}$. Untuk pengiriman dilakukan menggunakan mobil dengan pendingin.

Keamanan sayuran dipengaruhi kuat oleh proses pembersihan, pengemasan, dan penyimpanan. Pembersihan, pengemasan, dan penyimpanan yang tepat sesuai dengan karakteristik sayuran dilakukan untuk menghindari kontaminasi sehingga produk aman dikonsumsi.

Daya tahan pada produk sayuran dipengaruhi kuat oleh parameter pemanenan, pembersihan, pengemasan, dan penyimpanan. Pembersihan dilakukan dengan mencuci sayuran dengan air mengalir. Pengemasan dan penyimpanan dingin dapat meningkatan daya tahan produk sayuran karena kedua parameter tersebut secara umum dapat mengurangi laju respirasi sehingga dapat mencegah kelayuan dan kebusukan.

Warna sayuran dipengaruhi kuat oleh proses pemanenan, pembersihan, pengemasan, dan penyimpanan. Sayuran yang dipanen harus sesuai dengan umur panen, jika dipanen melewati umur panen, maka warna sayuran menjadi menyimpang dari warna standar sayuran. Pembersihan juga berpengaruh terhadap warna, sayuran yang tidak dibersihkan secara maksimal dapat menyebabkan warna menjadi kusam atau kotor. Pengemasan dan penyimpanan dingin dapat mempertahankan warna asli sayuran karena dapat mengurangi laju respirasi. 
Ukuran dan bentuk standar sayuran dipengaruhi kuat oleh proses sortasi karena pada proses ini dilakukan pemilahan berdasarkan ukuran dan bentuk yang standar. Selain itu bentuk yang standar oleh umur panen saat pemanenan. Sayuran harus dipanen sesuai dengan umurnya agar memperoleh sayuran dengan bentuk yang standar.

\section{B. Kemunduran}

Kemunduran produk hortikultura mulai terjadi begitu setelah panen. Kemunduran adalah batasan yang digunakan untuk menggambarkan segala perubahan yang mengarah pada kehilangan mutu seiring dengan adanya perubahan fisiologi, kerusakan mekanis, kehilangan air, dan segala bentuk kerusakan lainnya dari produk.

Sayuran daun mempunyai laju kemunduran mutu tinggi seperti pelayuan, penguningan daun dan pembusukan. Sayuran harus sesegera mungkin diberi penanganan pasca panen agar kualitasnya tetap terjaga dan memperkecil berbagai bentuk kehilangan. Untuk menekan kehilangan tersebut, pemahaman tentang sifat alami produk dan pengaruh cara penanganannya sangat penting untuk diketahui guna menjaga kondisi optimum produk. Beberapa pertimbangan penting yang harus diperhatikan, yaitu pertimbangan fisiologis, fisik, patologis, kondisi lingkungan dan ekonomis.

1. Pertimbangan fisiologis

Secara fisiologis bagian tanaman yang telah dipanen masih melakukan aktivitas metabolisme yang dinamakan respirasi. Respirasi berlangsung untuk memperoleh energi untuk aktivitas hidupnya. Dalam proses respirasi ini, bahan tanaman terutama kompleks karbohidrat dirombak menjadi bentuk karbohidrat yang 
paling sederhana (gula) selanjutnya dioksidasi untuk menghasilkan energi. Hasil sampingan dari respirasi ini adalah karbondioksida $\left(\mathrm{CO}_{2}\right)$, uap air $\left(\mathrm{H}_{2} \mathrm{O}\right)$ dan panas. Semakin tinggi laju respirasi maka semakin cepat pula perombakanperombakan tersebut yang mengarah pada kemunduran dari produk tersebut. Air yang dihasilkan akan ditranspirasikan dan jika tidak dikendalikan produk lebih cepat mengalami kelayuan. Sehingga laju respirasi sering digunakan sebagai index yang baik untuk menentukan masa simpan pasca panen produk segar.

Laju respirasi menentukan potensi pasar dan masa simpan yang berkaitan erat dengan; kehilangan air, kehilangan kenampakan yang baik, kehilangan nilai nutrisi dan berkurangnya nilai cita rasa. Masa simpan produk segar dapat diperpanjang dengan menempatkannya dalam lingkungan yang dapat memeperlambat laju respirasi dan transpirasi melalui penurunan suhu produk, mengurangi ketersediaan oksigen $\left(\mathrm{O}_{2}\right)$ atau meningkatkan konsentrasi $\mathrm{CO}_{2}$, dan menjaga kelembaban nisbi yang mencukupi dari udara sekitar produk tersebut.

2. Pertimbangan fisik

Kerusakan fisik dapat terjadi pada seluruh tahapan dari kegiatan pemanenan, penanganan, grading atau sortasi, pengemasan, transportasi, penyimpanan, dan akhirnya sampai ke tangan konsumen. Kerusakan yang umum terjadi adalah memar, terpotong, adanya tusukan-tusukan, bagian yang pecah, lecet dan abrasi. Kerusakan 
dapat pula ditunjukkan oleh dihasilkannya stress metabolit (seperti getah), terjadinya perubahan warna coklat dari jaringan rusak, menginduksi produksi gas etilen yang memacu proses kemunduran produk. Kerusakan fisik juga memacu kerusakan baik fisiologis maupun patologis (serangan mikroorganisme pembusuk).

3. Pertimbangan patologis

Sayuran mengandung air dalam jumlah yang banyak dan juga nutrisi yang mana sangat baik bagi pertumbuhan mikroorganisme. Mikroorganisme pembusuk dapat tumbuh bila kondisinya memungkinkan seperti adanya pelukaan-pelukaan, kondisi suhu dan kelembaban yang sesuai. Mikroorganisme pembusuk seperti Erwinia carotovora dan Pseudomonas marginalis (penyebab penyakit busuk lunak) pada sayuran mampu menghasilkan enzim yang mampu melunakkan jaringan. Jaringan tanaman dapat menghasilkan bahan pelindung sebagai respon dari adanya pelukaan. Bahan seperti lignin dan suberin, yang di akumulasikan dan diendapkan mengelilingi bagian luka, dapat sebagai pelindung dari serangan mikroorganisme pembusuk.

4. Pertimbangan kondisi lingkungan

Kondisi lingkungan yang berpengaruh terhadap kemunduran produk sayuran adalah suhu dan kelembaban. Suhu adalah faktor yang paling berpengaruh terhadap laju kemunduran dari komoditi pascapanen. Setiap peningkatan $10{ }^{\circ} \mathrm{C}$ laju kemunduran meningkat dua sampai tiga kali. Komoditi yang dihadapkan pada suhu yang tidak 
sesuai dengan suhu penyimpanan optimal, menyebabkan terjadinya berbagai kerusakan fisiologis. Kelembaban ruang berpengaruh terhadap kehilangan air setelah panen. Kehilangan air berarti kehilangan berat dan kenampakan. Kehilangan air tidak dapat dihindarkan namun dapat ditoleransi. Tandatanda kehilangan air bervariasi pada produk yang berbeda, dan tanda-tanda kerusakan baru tampak saat jumlah kehilangan air berbeda-beda pula. Umumnya tanda-tanda kerusakan jelas terlihat bila kehilangan air antara 3-8\% dari beratnya.

5. Pertimbangan ekonomi

Kondisi ekonomi dan standar kehidupan konsumen merupakan faktor yang harus dipertimbangkan dalam menentukan metode penanganan dan penyediaan fasilitas. Investasi berlebihan untuk penanganan pasca panen sayur dapat mengakibatkan economic loss, karena konsumen tidak mampu menyerap biaya tambahan. Hal ini menunjukkan bahwa penerapan metode penanganan sangat ditentukan oleh sejauh mana konsumen mau membayar lebih dengan tingkat penanganan yang lebih baik.

Produk pascapanen dihadapkan pada lima bentuk stress utama yang memacu laju kemunduran yang mengakibatkan berkurangnya masa simpan. Faktor-faktor pemicu kemunduran tersebut adalah:

1. Hilangnya suplai air

Pada saat budidaya, air diserap oleh sistem perakaran dan didistribusikan ke seluruh 
struktur tanaman melalui jaringan xylem. Dilain pihak, air yang disuplai secara berlanjut dilepaskan melalui proses transpirasi. Saat panen, suplai air mulai terhenti, namun proses transpirasi masih tetap berlangsung. Sayuran memiliki kandungan air tinggi (> 80\%), bahkan pada beberapa produk, seperti selada dan seledri kandungan airnya hingga 95\%. Hanya 2$3 \%$ dari air tersebut digunakan untuk proses biokimia dan menjaga turgiditas dari sel-sel. Turgiditas mencerminkan kandungan air sel. Turgiditas sangat penting sebelum dilakukan pemanenan dalam menyediakan dukungan mekanis untuk ketegarannya setelah panen, untuk komponen mutu seperti keberairan (juiceness), kerenyahan (crispness) dan kenampakan (appearance). Transpirasi setelah panen menyebabkan pengkerutan dan pelayuan, sehingga menurunkan mutu produk.

2. Tidak adanya aktifitas fotosintesis

Setelah panen, sayuran tidak dapat melakukan aktifitas fotosintesis dimana proses ini merupakan mekanisme tanaman untuk memperoleh makanan dan energi sehingga setelah pemanenan tidak terjadi produksi makanan, sedangkan proses metabolisme tanaman masih berjalan setelah panen.

3. Penempatan diluar kondisi suhu normalnya Perubahan suhu selama pasca panen dapat mempercepat proses penurunan.

4. Kerusakan mekanis akibat pemanenan

Kerusakan mekanis akibat pemanenan akan menyebabkan produk menjadi stress dan 
perubahan rekasi metabolisme. Produk secara alami akan memproduksi etilen sebagai respon adanya kerusakan. Etilen adalah hormon tanaman yang mengendalikan fase pelayuan (atau kematian) di dalam tanaman.

5. Meningkatnya kepekaan terhadap serangan mikroorganisme pathogen. Mikroorganisme pathogen tidak agresif menyerang produk segar, mereka membutuhkan entry site untuk menginvasi jaringan dan melakukan infeksi. Panen akan mengkreasi berbagai tempat dari pathogen untuk melakukan invasi, seperti adanya kerusakan mekanis, fisiologi dan kerusakan karena insekta. Semakin banyak kerusakan-kerusakan tersebut, maka semakin tinggi kepekaannya terhadap infeksi mikroorganisme.

\section{Kehilangan Pasca Panen}

Dalam proses penanganan pascapanen, terjadi kehilangan / susut yang besarnya bervariasi tergantung kepada macam, jenis, varietas, dan cara penanganan jenis hasil pertanian. Kehilangan atau susut pascapanen ini dapat disebabkan oleh beberapa faktor dan kehilangan / susut ini dapat dikelompokkan menjadi tiga kategori yang masingmasing mempunyai implikasi ekonomis yaitu kehilangan / susut kuantitatif, kualitatif, dan kehilangan nutrisi.

Kehilangan / susut kuantitatif yaitu pengurangan berat yang dengan mudah dapat diukur secara kuantitatif. Kehilangan/susut kualitatif yaitu kehilangan yang sukar diukur secara kuantitatif dan biasanya didasarkan pertimbangan subjektif, sedangkan kehilangan nilai nutrisi merupakan kombinasi kehilangan kuantitatif dan kualitatif. 
Kehilangan kualitatif bahan pangan dapat disebabkan karena kerusakan, kontaminasi, dan perubahan-perubahan nutrisi.

Jenis kerusakan dan kehilangan yang kurang mendapat perhatian adalah dalam bentuk kehilangan kualitatif berupa rusaknya nilai gizi. Data yang telah terkumpul memberi petunjuk bahwa jenis hama tertentu justru menyerang bagian-bagian yang paling bergizi, yang mengandung vitamin dan protein tertinggi. Meskipun demikian, ungkapan penanganan pasca panen merupakan suatu pengertian yang kompleks karena didalamnya bukan saja melibatkan faktor-faktor teknis tetapi juga faktor sosial dan ekonomi.

Di dalam suatu sistem yang sederhana, yang para petaninya menanam, memanen, dan mengkonsumsi hasil panennya sendiri segera setelah panen, masalah kehilangan dan kerusakan memang kecil dan kurang berarti. Akan tetapi, di suatu daerah yang para petaninya harus menyimpan hasil panennya, maka masalah pasca panen mulai timbul. Masalah tersebut menjadi lebih serius di daerah yang mempunyai iklim tropis lembab seperti di Indonesia. Dengan alasanalasan inilah maka dikembangkanlah penanganan pasca panen yang terpadu dan efektif dalam usaha meningkatkan persediaan bahan pangan di Indonesia. Di mana cara penanganan pasca panen sebaiknya dilakukan dengan pendekatan sistem atau dengan konsep utuh dan terpadu.

Faktor-faktor yang menyebabkan turunnya kualitas dan susut panen adalah:

1. Turunnya kadar air

Masa simpan sayuran daun tergantung pada kandungan atau kadar airnya. Secara umum, semakin tinggi jumlah kandungan air dalam makanan, maka semakin cepat makanan tersebut 
rusak. Pada komoditas sayuran kandungan air yang tinggi berbanding lurus dengan kualitas kesegaran, maka penurunan kadar air pada sayuran daun dapat menyebabkan kelayuan dan perubahan warna pada daun. Selain itu, secara kuantitatif penurunan kadar air juga dapat mengakibatkan susut berat/bobot sayuran.

2. Kerusakan mekanis selama pengiriman dan penyimpanan

Kerusakan mekanis disebabkan oleh adanya benturan-benturan mekanis, seperti benturan antar produk sayuran atau benturan antara bahan pengemasan atau peralatan dengan produk. Gejala kerusakan yang timbul antara lain memar (karena tertindih/tertekan), gepeng, sobek atau terpotong, dan lain-lain. Kerusakan mekanis juga menjadi penyebab kerusakan lain seperti kerusakan akibat mikroba pathogen dan pembusuk yang lebih mudah menginfeksi jaringan apabila terdapat luka.

3. Penguapan (transpirasi)

Transpirasi adalah proses fisik dimana uap air lepas dari jaringan tanaman berevaporasi ke lingkungan sekitar. Penguapan atau proses transpirasi setelah panen menyebabkan turunnya kadar air yang berakibat pada pengkerutan serta pelayuan, sehingga menurunkan mutu produk.

4. Berkembangnya mikroba

Kerusakan dan kehilangan karena pembusukan untuk produk segar adalah cukup tinggi. Kerusakan ini adalah paling besar terutama berakibat terhadap penurunan mutu. Kebanyakan infeksi yang dilakukan oleh 
mikroorganisme pathogen melalui jaringan yang rusak secara mekanis (luka atau kulit yang tertusuk). Dengan demikian metode penanganan setelah panen akan sangat menentukan besarkecilnya proses pembusukan pasca panen.

Selama penyimpanan, kehilangan/susut dan kerusakan dapat disebabkan oleh insekta, jamur, bakteri, tikus, burung, dan karena berkecambah. Proses ini dipengaruhi oleh faktor cuaca, kelembaban, dan suhu. Selama proses pengolahan dan pengepakan, kehilangan/susut dan kerusakan dapat terjadi kerena pengupasan dan pemotongan berlebihan dan dapat terjadi kontaminasi.

\section{Ringkasan}

Karakteristik penting komoditas sayur pasca panen adalah bahan tersebut masih hidup dan masih melakukan aktifitas metabolismenya. Aktivitas metabolisme pada sayuran segar dicirikan dengan adanya proses respirasi. Respirasi dijadikan sebagai indikator dari aktivitas metabolisme dalam jaringan. Aktivitas ini memecah karbohidrat yang diproduksi selama proses fotosintesis dengan ketersediaan $\mathrm{O}_{2}$ yang menghasilkan $\mathrm{CO}_{2}, \mathrm{H}_{2} \mathrm{O}$ dan energi.

Respirasi memproduksi panas. Panas yang dihasilkan ini menyebabkan masalah selama pendistribusian produk. Awal peningkatan respirasi sejalan atau linier dengan peningkatan suhu. Jika produk di ekspos pada suhu sekitar 45 ${ }^{\circ} \mathrm{C}$ atau lebih tinggi, produk mulai mati dan respirasi mulai terhenti atau menurun cepat menuju kematian. Kecepatan respirasi akan mempercepat kemunduran produk. 
Kemunduruan adalah batasan yang digunakan untuk menggambarkan segala perubahan yang mengarah pada kehilangan mutu seiring dengan adanya perubahan fisiologi, kerusakan mekanis, kehilangan air, dan segala bentuk kerusakan lainnya dari produk. Kualitas sayuran daun yang paling umum dijelaskan berdasarkan kesegaran, kebersihan, dan kecerahan warna daunnya. Kesegaran sayuran daun berbanding lurus dengan kandungan airnya. Kehilangan air dapat berakibat terhadap kehilangan secara kualitatif dan kuantitatif dari produk.

Sayuran harus sesegera mungkin diberi penanganan pasca panen agar kualitasnya tetap terjaga dan memperkecil berbagai bentuk kehilangan. Untuk menekan kehilangan tersebut, pemahaman tentang sifat alami produk dan pengaruh cara penanganannya sangat penting untuk diketahui guna menjaga kondisi optimum produk. Beberapa pertimbangan penting yang harus diperhatikan, yaitu pertimbangan fisiologis, fisik, patologis, kondisi lingkungan dan ekonomis.

Produk pascapanen dihadapkan pada lima bentuk stress utama yang memacu laju kemunduran yang mengakibatkan berkurangnya masa simpan. Faktor-faktor pemicu kemunduran tersebut yaitu: 1) hilangnya suplai air; 2) tidak adanya aktifitas fotosintesis; 3) penempatan diluar kondisi suhu normalnya; 4) kerusakan mekanis akibat pemanenan; dan 5) meningkatnya kepekaan terhadap serangan mikroba pathogen. 


\section{E. Latihan soal}

\section{Tugas Individu}

1. Mengapa kualitas produk penting untuk diperhatikan?

2. Jelaskan hubungan antara kualitas produk dengan parameter penanganan teknis selama pemanenan!

3. Jelaskan pertimbangan ekonomi dalam menentukan metode penanganan produk dalam upaya untuk menjaga kondisi optimum produk!

4. Sebutkan dan jelaskan faktor-faktor yang menyebabkan turunnya kualitas dan susut panen!

5. Mengapa kadar air sayuran berpengaruh terhadap kualitas dan kuatintas produk?

\section{Tugas Kelompok}

Cari satu jurnal mengenai kemunduran dan penanganannya pada produk hortikultura (terutama mengenai sayuran daun), pelajari metode penangannya, kemudian presentasikan kemunduran-kemunduran yang terjadi.

\section{Daftar Pustaka}

David, J. H. dan J. C. Kilmanun. 2016. Penanganan Pasca Panen Penyimpanan untuk Komoditas Hortikultura. Prosiding Seminar Nasional Inovasi Teknologi Pertanian. Banjarbaru.

Hayati, R., Syamsuddin, dan Halimursyadah. 2015. Teknologi Pasca Panen. Buku Ajar. Universitas Syiah Kuala. Banda Aceh. 
Sudjatha, W. dan N. W. Wisaniyasa. 2017. Fisiologi dan Teknologi Pascapanen (Buah dan sayuran). Buku Ajar. Udayana University Press.

Yuarini, D. A. A., I. K. Satriawan, dan I. D. P. O. Suardi. 2015. Strategi Peningkatan Kualitas Produk Sayuran Segar Organik pada CV. Golden Leaf Farm Bali. Jurnal Manajemen Agribisnis 3 (2): 93-109.

Utama, I. M. S. Kemunduran Produk Hortikultura Segar. Bahan Ajar 4. Fisiologi dan Teknik Pascapanen Hortikultura.

Utama, I. M. S. dan N. S. Antara. Modul Kuliah. Pasca Panen Tanaman Tropika: Buah dan Sayur. Tropical Plant Curruculum Project. Universitas Udayana. 


\section{BAB IV \\ TEKNOLOGI PASCA PANEN UNTUK SAYURAN DAUN}

Istilah pascapanen mulai populer di Indonesia tahun 1970 setelah diketahui bahwa produksi padi sejak panen sampai tiba di tangan konsumen banyak mengalami kerusakan, susut dan kehilangan bobot. Penggunaan istilah pascapanen bermacam-macam. Ada yang menyebutnya dengan penanganan pascapanen, teknologi penanganan pascapanen, dan ada juga yang memberi istilah teknologi pascapanen.

Penanganan pascapanen (teknologi pascapanen) meliputi hal berikut ini:

1. Semua kegiatan perlakuan, penanganan (handling), dan pengolahan langsung terhadap produksi pertanian tanpa mengubah struktur asli produk tersebut. Contohnya adalah pemanenan itu sendiri, perontokan biji, penyimpanan atau penggudangan, pengawetan, penggilingan, standarisasi mutu produk, pengemasan, penanganan produk dalam transportasi, dan pemasaran.

2. Pengolahan segera dilakukan karena sifat hasil panennya. Misalnya, umbi ketela pohon (ubi kayu) tidak dapat disimpan lama dan patinya harus segera diekstrak. Demikian juga tebu yang baru dipanen harus segera digiling, karena bila tidak segera digiling cairan tebu tersebut akan segera rusak; sukrosanya akan terurai.

Kegiatan penanganan pascapanen mencakup pemanenan hasil, pengawetan, pengemasan, penyimpanan/ penggudangan, standarisasi mutu, dan transportasi di tingkat 
produksi. Selanjutnya, ditegaskan bahwa tujuan penanganan pascapanen tanaman pangan adalah:

1. Menekan tingkat kehilangan dan atau tingkat kerusakan hasil panen tanaman pangan,

2. Meningkatkan daya simpan dan daya guna hasil tanaman pangan agar dapat menunjang usaha penyediaan pangan dan perbaikan gizi masyarakat,

3. Menyediakan bahan baku industri di dalam negeri,

4. Meningkatkan pendapatan petani,

5. Meningkatkan penerimaan devisa negara,

6. Merperluas kesempatan kerja, dan

7. Melestarikan sumber daya alam dan lingkungan hidup.

Jadi, dengan penanganan pascapanen hasil pertanian, akan diperoleh bahan baku yang berkualitas baik dengan cara mencegah atau mengurangi terjadinya kehilangan dan atau kerusakan hasil panen. Hasil panen yang telah melalui proses penanganan pascapanen dapat dikonsumsi oleh konsumen tanpa melalui proses pengolahan lebih lanjut atau dapat sebagai bahan baku untuk diolah dalam industri pengolahan hasil pertanian.

Sayuran merupakan bahan pangan yang mempunyai sifat mudah rusak (perishable). Pada umumnya mutu sayursayuran tidak dapat diperbaiki tetapi dapat dipertahankan. Mutu yang baik akan diperoleh bila pemanenan dilakukan pada tingkat kematangan yang tepat, cara panen yang baik serta penanganan pascapanen yang tepat. Kerusakan sayuran daun (sawi, bayam, kangkung, selada, dll) pada pemanenan adalah daun yang berlobang, tangkai daun patah sehingga mempercepat pelayuan. Kerusakan menjadi lebih 
besar biasanya disebabkan penanganan pascapanen yang tidak baik.

Kerusakan sayuran daun terjadi pada berbagai tahapan pra panen hingga pascapanen. Beberapa faktor kerusakan yaitu:

1. Tahapan prapanen

Pada tahap ini faktor kerusakan disebabkan oleh hama penyakit lapangan, busuk pangkal batang, ulat daun, dan serangga (belalang).

2. Panen

Faktor kerusakan antara lain penumpukan sayur di atas tanah dan penjemuran di bawah sinar matahari.

3. Pascapanen

Faktor kerusakan sayuran daun pada tahap pascapanen yaitu pengikatan sayur yang erat, tumpukan sayur diatas tanah dan penumpukan dengan jenis sayuran lain. Sayur yang diikat menyebabkan kerusakan mekanis. Setiap sobekan, memar, atau kerusakan lain yang menimpa jaringan sayuran akan memberi jalan bagi mikroba untuk masuk. Suhu yang tinggi akan merangsang berkembangbiaknya mikroba. Sebaliknya, suhu yang rendah akan menghambat pertumbuhan mikroba.

\section{A. Pemanenan}

Menjaga kualitas sayuran daun dapat dilakukan dengan cara mengurangi atau menghindari kerusakan sayuran sebelum panen dan saat lepas panen. Penanganan sayuran daun yang baik: 
1. Panen pada umur panen yang tepat (pada umumnya sayuran daun dapat dipanen 21 hari setelah tanam (hst)).

2. Panen pada Indeks panen yang tepat (daun berwarna hijau terang dan tekstur batang tegar).

3. Panen pada waktu yang tepat (panen pada pagi hari untuk mengurangi proses penguapan yang dapat mempercepat pelayuan).

4. Hindari penumpukan sayuran untuk mencegah kerusakan mekanis, fisik maupun fisiologis yang memberikan kerusakan terhadap komoditi.

5. Lakukan pemotongan akar untuk menghindari kontaminasi kotoran, pencucian sayuran pada air mengalir dan pengemasan.

Pelaksanaan pemanenan harus memperhatikan umur tanaman siap panen dan cara panennya. Pemanenan yang terlambat dilakukan menyebabkan tanaman cepat berbunga. Panen sebaiknya dilakukan pada waktu hari tidak terlalu panas untuk menghidarkan layu, pagi atau sore sekali. Hasil panen sebaiknya disimpan di tempat yang teduh dan sejuk. Berikut beberapa kriteria sayuran daun siap panen yaitu:

1. Sawi

Umur panen sawi paling lama 70 hari. Paling pendek umur 40 hari, terlebih dahulu melihat fisik tanaman seperti warna, bentuk dan ukuran daun. Cara panen ada 2 macam yaitu mencabut seluruh tanaman beserta akarnya dan dengan memotong bagian pangkal batang yang berada di atas tanah dengan pisau tajam

2. Bayam

Bayam siap panen 20-45 hari setelah tanam. Panen dapat dilakukan dengan dua cara yaitu 
sekali panen dimana pemanenan dilakukan pada seluruh bagian tanaman untuk bayam cabut dan beberapa kali panen dengan cara memetik daun dan batang muda dengan interval 2-3 kali/minggu untuk bayam petik.

Setelah ditanam, bayam cabut biasanya akan dipanen ketika sudah mencapai ketinggian ratarata yakni sekitar $20 \mathrm{~cm}$. Untuk mencapai ketinggian tersebut, biasanya tanaman bayam cabut memerlukan waktu kurang lebih tiga minggu setengah. Senada dengan namanya, jenis bayam cabut kita panen dengan cara mencabut tanaman hingga akarnya terlepas dari tanah.

3. Kangkung

Kangkung air siap dipanen 30 - 45 hst, tergantung dari varietas dan tipe tanaman kangkung. Panen dapat dilakukan sekali sampai beberapa kali. Untuk panen yang berulang, tunas dipotong $15-20 \mathrm{~cm}$ dari permukaan tanah, biasanya seminggu sekali. Panen yang berulang menghambat pembungaan dan merangsang tumbuhnya tunas lateral yang berkembang menjadi tunas batang baru

4. Bawang daun

Tanaman bawang daun mulai dapat dipanen pada umur 2 bulan setelah tanam. Potensi hasilnya berkisar antara 7-15 ton/ha. Pemanenan dilakukan dengan mencabut seluruh bagian tanaman termasuk akar, buang akar dan daun yang busuk atau layu. Apabila Bawang daun akan ditanam kembali pada pertanaman berikutnya, maka dilakukan pemilihan tunas anakan yang sehat dan bagus pertumbuhannya kemudian 
dipisahkan dari bagian tanaman yang hendak dijual.

5. Kubis

Kubis dapat dipanen setelah kropnya besar, penuh dan padat. Bila pemungutan terlambat, krop akan pecah dan kadang-kadang busuk. Pemungutan dilakukan dengan memotong krop berikut sebagian batang dengan disertakan 4-5 lembar daun luar, agar krop tidak mudah rusak. Produksi kubis dapat mencapai 15-40 ton/ha.

6. Seledri

Tanaman seledri yang di tanam secara langsung tanpa melalui pesemaian dapat dipanen pada umur 160-180 hari, sedangkan seledri yang ditanam dari persemaian biasanya di panen pada umur 90-125 hari. Tanaman seledri biasanya dipanen ketika sebagian besar tanaman dianggap telah mencapai fase layak jual, tetapi ukuran yang agak beragam tidak dapat dihindari. Penundaan panen dapat menyebabkan sebagian tanaman menjadi bergabus, sedangkan panen yang terlalu dini berakibat sedikitnya tangkai daun yang berukuran besar. Panen dilakukan dengan cara dicabut. Seledri daun memiliki musim tanam yang lebih pendek, dan panen dapat dilakukan berulang kali jika daun dipotong cukup tinggi di atas permukaan tanah untuk memungkinkan pertumbuhan kembali daun baru. Produksi seledri dapat mencapai 40-70 ton/ha.

7. Selada

Tanaman selada dapat dipanen setelah berumur \pm 2 bulan. Panen dapat dilakukan dengan cara mencabut batang tanaman dengan akar-akarnya 
atau memotong pangkal batang. Tanaman yang baik dapat menghasilkan \pm 15 ton /ha. Panen selada dilakukan dengan mencabut tanaman sampai keakar-akarnya. Setelah dipanen, bagian akar selada dicuci dan daun-daun yang rusak dibuang.

8. Katuk

Tanaman katuk biasanya mencapai ketinggian 70 $\mathrm{cm}$ atau lebih pada umur 3-3,5 bulan setelah tanam. Pada tahap ini dapat dilakukan pemanenan pertama. Panen dilakukan dengan cara memangkas ujung tanaman atau cabang menggunakan pisau yang tajam. Pucuk dipangkas atau dipotong sapanjang 10-15 cm. Waktu panen yang paling baik adalah pada pagi atau sore hari dan kondisi cuaca cerah. Pemanenan berikutnya dilakukan secara kontinyu sebulan sekali.

\section{B. Penanganan di lapang produksi}

Sebelum dilakukan penanganan pascapanen, telah dilakukan penanganan prapanen yang dilaksanakan di lapangan atau di kebun terhadap komoditas sayuran, termasuk perlakuan yang dilakukan menggunakan senyawa kimia untuk mencegah pembusukan yang disebabkan oleh mikroba terhadap komoditi. Bentuk-bentuk kerusakan lain seperti perkecambahan, kehilangan air, kerusakan dalam penyimpanan, dan serangan insekta dapat diperkecil dengan perlakuan kimia.

\section{Perlakuan di Packing House}

Komoditas sayuran harus sesegera mungkin diberi penanganan pasca panen agar kualitasnya tetap terjaga dan memperkecil berbagai bentuk kehilangan. Secara spesifik 
penanganan pasca panen terhadap sayuran meliputi pencucian, sortasi, dan grading.

Hampir semua komoditas sayuran yang telah dipanen mengalami kontaminasi fisik terutama debu atau tanah sehingga perlu dilakukan pencucian. Pencucian dilakukan dengan tujuan untuk menghilangkan kotoran serta residu pestisida (insektisida atau fungisida). Secara tradisional pencucian ini menggunakan air namun untuk mendapatkan hasil yang lebih baik disarankan penambahan klorin ke dalam air pencucian agar mikroba dapat dihilangkan dengan lebih efektif. Setelah pencucian biasanya bahan dikeringkan dengan cara meniriskannya di alam terbuka.

Nilai ekonomi berbagai jenis hortikultura tergantung pada mutu komoditas tersebut. Oleh karena itu proses pemisahan antar komoditas (sortasi) yang mutunya rendah dengan yang mutunya tinggi perlu dilakukan. Pemisahan tersebut berdasarkan ukuran, tingkat kematangan, rusak, lecet, memar, busuk, warna, dan sebagainya. Perlakuan sortasi tergantung juga kepada peruntukannya atau tempat pemasarannya (misalnya pasar swalayan, restoran, atau hotel).

Grading hampir sama dengan sortasi. Kalau sortasi adalah pemisahan/pengelompokan berdasarkan mutu yang erat kaitannya dengan kondisi fisik sayuran (busuk, rusak, daun sobek, dan lain sebagainya) sedangkan grading lebih kearah nilai estetikanya (warna, dimensi). Kombinasi sortasi dan grading menghasilkan standar mutu sayuran dimana ada jenis sayuran memiliki satu atau lebih standar mutu.

\section{Pengepakan dan Pengemasan}

Dengan adanya kemajuan dalam pengemasan, konsumen akan dapat menerima komoditi dalam keadaan 
lebih segar, kerusakan yang lebih sedikit, potensi ketahanan yang lebih baik daripada sebelumnya. Sebelum adanya pengemasan yang lebih baik serta fasilitas pengangkutan dan pendinginan, maka tidak ada kemungkinan dilakukan distribusi komoditi yang mudah rusak secara luas. Dua fungsi utama pengemasan yaitu merakit bahan produk dalam kesatuan yang mudah untuk dibawa dan melindungi terhadap kerusakan selama pemasaran dan penyimpanan.

Umumnya pengemasan dapat mengurangi susut berat atau pengkerutan yang terjadi pada bahan segar selama pemasaran, seperti pembungkusan individual atau bersama sama dalam satuan yang kecil dalam kantong plastik atau kertas lilin, pelapisan kemasan dengan lilin. Dalam keadaan kering, peti kayu atau keranjang komoditi dapat disemprot dengan air. Perlakuan dengan pembasahan tersebut dimaksudkan untuk membantu pendinginan komoditi oleh karena terjadinya penguapan air yang disemprotkan itu.

Pengemasan dilakukan secara bertahap dimana pada tahap pertama (primer) dimana sayuran dikemas dengan bahan plastik atau kertas agar bahan terhindar dari kerusakan akibat gesekan atau benturan sesama bahan maupun dengan benda lain sehingga mutunya dapat tetap dipertahankan. Selanjutnya dilakukan tahap kedua (sekunder) dimana sayuran dikemas karton atau kotak kayu. Selanjutnya karton atau kotak kayu tersebut disimpan di atas suatu pallet untuk kemudian dikirim ke ruang pendingin.

Untuk mempertahankan kesegaran dan ketegaran sayur dapat dilakukan pengemasan. Penggunaan kemasan plastik sebagai bahan pengemas mempunyai keunggulan dibandingkan dengan bahan kemasan lainnya. Kemasan ini memiliki sifat yang ringan dan mempunyai adaptasi yang 
tinggi terhadap produk, tidak korosif seperti wadah logam, transparan, kuat, termoplastik dan memiliki permeabilitasnya terhadap uap air, $\mathrm{CO}_{2}$, dan $\mathrm{O}_{2}$.

\section{E. Pendinginan dan Penyimpanan}

Kehilangan air selama proses penyimpanan terjadi pada suhu tinggi sehingga perlu diusahakan agar kelembaban dipertahankan relatif tinggi. Kelembaban dapat ditingkatkan dengan penyemprotan lantai penyimpanan dengan air, namun kelembaban tinggi menyebabkan jamur mudah tumbuh termasuk pada dinding ruangan. Perlu dilakukan pembersihan dinding ruangan secara teratur dengan menggunakan larutan natrium hidrokhlorit (khlorin) yang disertai fumigasi dengan menggunakan gas formaldehida.

Berikut beberapa tips untuk menjaga kesegaran sayuran daun selama masa penyimpanan:

1. Seleksi (sortasi) sayuran sebelum disimpan.

2. Buang bagian yang mengalami kerusakan (patah, memar, sobek, atau terkontaminasi mikroba).

3. Cuci sayuran dengan air yang mengalir.

4. Simpan sayuran dalam kemasan plastik yang memiliki permeabilitas untuk menjaga sirkulasi $\mathrm{CO}_{2}$ dan $\mathrm{O}_{2}$.

5. Simpan sayuran didalam kulkas (suhu dingin).

Salah satu faktor yang sangat berpengaruh terhadap penurunan mutu sayuran adalah perubahan kadar air. Perubahan kadar air dipengaruhi oleh suhu dan kelembaban ruangan selama penyimpanan. Tabel 2 menunjukkan perubahan kadar air beberapa jenis sayuran daun setelah panen dan selama penyimpanan yang dikemas menggunakan plastic wrap. 
Tabel 2. Kadar Air Sayuran Setelah Panen dan Selama Penyimpanan

\begin{tabular}{|l|c|c|c|c|}
\hline \multirow{2}{*}{ Komoditas } & \multicolumn{4}{|c|}{ Kadar air (\%) } \\
\cline { 2 - 5 } & Awal & Suhu $25^{\circ} \mathrm{C}$ & Suhu $5^{\circ} \mathrm{C}$ & Suhu $-4^{\circ} \mathrm{C}$ \\
\hline Kubis merah & 87,00 & 87,40 & 82,40 & 87,20 \\
\hline Selada krop & 95,80 & 96,00 & 96,00 & 73,80 \\
\hline Brokoli & 86,60 & 86,60 & 83,40 & 90,00 \\
\hline Bunga kol & 91,20 & 79,20 & 77,20 & 87,00 \\
\hline
\end{tabular}

Sumber: Murtiwulandari dkk., 2020.

Sayuran daun yang dikemas dalam plastic wrap akan mengalami peningkatan kadar air selama penyimpanan dan peningkatan pada suhu kamar $\left(25^{\circ} \mathrm{C}\right)$ relatif lebih tinggi dibandingkan dengan suhu rendah. Hal ini terjadi akibat adanya jumlah air metabolit sebagai hasil samping proses respirasi lebih banyak dibandingkan dengan air yang menguap melalui proses transpirasi, sehingga terjadi akumulasi air di antara sel.

Untuk memperoleh hasil penyimpanan yang baik, suhu ruang pendingin harus dijaga agar tetap konstan dan tidak berfluktuasi. Hal ini dapat diatasi dengan penggunaan isolator ruangan dan tenaga mesin pendingin yang cukup. Cara penumpukan yang tepat dan sirkulasi udara yang cukup sangat membantu memperkecil variasi suhu.

Banyak cara untuk mendinginkan produk setelah panen. Teknik pendinginan dapat menggunakan udara, air, evaporasi air dan es sebagai coolant. Beberapa teknik pendinginan yang cocok untuk sayuran daun yaitu hydrocooling, vacuum cooling, dan package icing. 


\section{a. Hydro-cooling}

Penggunaan air dingin untuk mempercepat pendinginan dalam wadah simpan merupakan teknik pendinginan yang telah berkembang cukup lama dan juga merupakan teknik pendinginan yang efektif. Teknik ini digunakan untuk pendinginan sayuran dalam peti sebelum dipaking. Oleh karena itu, maka bahan wadah harus tahan terhadap air (kebasahan). Walaupun cukup efektif untuk mendinginakan komoditi yang disimpan, namun untuk selang beberapa waktu, air pendingin akan berangsur-angsur menjadi hangat kembali sehingga pada saat ini mungkin saja diperlukan lagi pengemasan ulang karena diperlukannya memasukkan air pendingin lagi. Jadi efisiensi pendinginan akan diperoleh hanya jika terdapat sumber air pendingin otomatis yang dihubungkan dengan wadah penyimpanan komoditi bersangkutan.

b. Vacuum cooling

Teknik penyimpanan dingin ini efektif untuk penyimpanan sayuran daun seperti kembang kol dan seledri. Pendinginan diperoleh dengan cara mengurangi tekanan atmosfir di dalam wadah (ruangan) yang besar dan kuat. Biasanya terbuat dari bahan baja. Pengurangan tekanan atmosfir juga mengurangi tekanan uap air dalam wadah (kontainer). Apabila tekanan uap air dalam kontainer berkurang hingga di bawah yang ada di ruangan antar sel, maka air akan mengalami evaporasi dari komoditi. Teknik vacuum cooling dapat menyebabkan kehilangan berat (umumnya 
air) sebesar $1 \%$ untuk setiap penurunan suhu $6^{\circ} \mathrm{C}$.

c. Package icing

Beberapa komoditi didinginkan dalam penyimpanannya dengan cara memasukkan sejumlah es ke dalam wadah paking. Awalnya kontak langsung antara komoditi yang disimpan dengan es akan menyebabkan pendinginan yang cepat. Lambat laun, es akan mencair dan saat itu terjadi, pendinginan lambat laun semakin lamban. Es yang diberikan atau dimasukkan dalam wadah simpan dapat berupa bongkahan es ataupun hancuran es batu beserta sedikit air. Karena es langsung dimasukkan dalam wadah, maka persyaratan bahan wadah haruslah tahan air dan tidak mudah bocor merupakan hal yang harus diperhatikan.

Kelembaban nisbi dalam ruang penyimpanan dingin secara langsung mempengaruhi mutu sayuran yang disimpan. Jika kelembaban rendah maka akan terjadi pelayuan atau pengkeriputan, dan jika kelembaban terlalu tinggi akan merangsang proses pembusukan karena kemungkinan terjadi kondensasi air. Udara dalam ruang pendingin perlu disirkulasikan agar suhu ruangan dapat merata. Untuk itu jarak tumpukan harus sedemikian rupa agar tidak menghalangi arus udara dingin.

Mengkombinasikan penyimpanan dingin dengan pengurangan konsentrasi oksigen dan peningkatan konsentrasi karbondioksida dalam ruang penyimpanan akan memberikan hasil penyimpanan yang sangat baik. Proses kerusakan baik aspek fisiologis maupun mikrobiologis akan efektif dihambat. 
Teknik penyimpanan ini ditemukan oleh Kidd dan West (1920-an) dan kemudian dikembangkan oleh Phillip (1940-an) yang dikenal sebagai penyimpanan atmosfir terkendali (controlled atmosphere storage $=$ CA-storage). Selain itu, berkembang pula teknik penyimpanan lainnya yang kemudian dikenal sebagai penyimpanan atmosfir termodifikasi (modified atmosphere storage = MA-storage), self controlled atmosphere storage (SCA-storage), $\mathrm{CO}_{2-}$ treatment, dan low pressure (LP) atau dikenal sebagai hypobaric storage.

Pada CA-storage, konsentrasi oksigen dikurangi sedangkan konsentrasi karbondioksida ditambahkan dengan sengaja ke dalam wadah (kontainer) simpan. Lain halnya dengan MA-storage, kondisi atmosfir dimodifikasi oleh wadah tertutup. Kandungan oksigen dikurangi oleh komoditi yang disimpan melalui respirasi. Sedangkan konsentrasi gas karbondioksida ditentukan oleh permeabilitas lapisan (film) yang ada dalam wadah, respirasi, suhu, dan kondisi penutupan wadah.

Hypobaric storage adalah cara penyimpanan dalam udara terkendali yang ditekankan pada penurunan tekanan pada bahan yang disimpan. Cara ini tidak hanya mengurangi konsentrasi $\mathrm{O}_{2}$, tetapi mempercepat difusi $\mathrm{C}_{2} \mathrm{H}_{4}$ (etilen) keluar dari jaringan sehingga dapat memperpanjang umur simpannya.

Kecepatan respirasi dan metabolisme sayuran yang disimpan dengan sistem penyimpanan pada atmosfir terkendali atau termodifikasi akan menurun bukan hanya akibat pengaruh suhu rendah, tetapi juga karena konsentrasi oksigen yang rendah dan konsentrasi gas karbon dioksida yang tinggi. Yang perlu diperhatikan adalah menjaga agar 
konsentrasi oksigen tidak terlalu rendah, karena akan menyebabkan terjadinya fermentasi dan kebusukan.

Pada sayuran warna hijau, peningkatan ketahanan warna hijau pada kadar oksigen udara yang rendah dalam udara diakibatkan oleh rendahnya laju kerusakan khlorofil pada kondisi tersebut. Pada selada dengan peningkatan karbon dioksida selama penyimpanan, laju pembebasan karbon dioksida berkurang. Apabila kandungan oksigen selama waktu peralihan diturunkan di bawah tingkat udara atmosferik biasa, laju respirasi akan berkurang. Bila brokoli disimpan pada suhu $75{ }^{\circ} \mathrm{F}$ dengan berbagai konsentrasi oksigen terutama bila oksigennya diturunkan dari 20,9\% sampai $0 \%$, terrjadi penurunan respirasi.

\section{F. Transportasi}

Pengelolaan suhu merupakan hal yang sangat penting dalam pengangkutan dengan jarak tempuh jauh, untuk itu muatan harus disusun sedemikian rupa agar terjadi sirkulasi udara yang baik yang dapat membawa keluar panas yang dihasilkan oleh produk dan juga akibat hawa panas yang datang dari udara sekitarnya serta panas jalan. Selama pengangkutan, produk hasil pertanian harus disusun sedemikian rupa sehingga kerusakan dapat diminimumkan kemudian diperkuat dan aman. Muatan atau produk dalam kendaraan bak terbuka dapat diatur sedemikian rupa sehingga udara bisa mengalir melalui produk yang dapat mendinginkan produk itu sendiri selama kendaraan melaju.

Perjalanan pada malam dan pagi hari bisa mengurangi beban panas (heat load) pada kendaraan yang mengangkut hasil panen. Pengangkutan campuran beberapa jenis produk hortikultura adalah hal yang biasa dilakukan, khususnya untuk pengiriman sayur-sayuran. Berbagai macam 
penutup palet bisa digunakan untuk menutupi produk yang didinginkan selama proses penanganan dan pengangkutan. Penutup dari bahan polietilen harganya murah dan ringan, serta melindungi palet dari debu, kelembaban dan mengurangi peningkatan suhu. Penutup berinsulasi ringan dapat melindungi muatan dari proses peningkatan panas untuk beberapa jam (misalnya, jika terjadi penundaan proses pemuatan). Penutup berinsulasi tebal terkadang digunakan untuk melindungi produk-produk tropis dari hawa dingin pada saat pengiriman selama musim dingin.

\section{G. Ringkasan}

Kegiatan penanganan pascapanen mencakup pemanenan hasil, pengawetan, pengemasan, penyimpanan/ penggudangan, standarisasi mutu, dan transportasi di tingkat produksi. Dengan penanganan pascapanen hasil pertanian, akan diperoleh bahan baku yang berkualitas baik dengan cara mencegah atau mengurangi terjadinya kehilangan dan atau kerusakan hasil panen. Hasil panen yang telah melalui proses penanganan pascapanen dapat dikonsumsi oleh konsumen tanpa melalui proses pengolahan lebih lanjut atau dapat sebagai bahan baku untuk diolah dalam industri pengolahan hasil pertanian.

Sayuran merupakan bahan pangan yang mempunyai sifat mudah rusak (perishable). Pada umumnya mutu sayursayuran tidak dapat diperbaiki tetapi dapat dipertahankan. Mutu yang baik akan diperoleh bila pemanenan dilakukan pada tingkat kematangan yang tepat, cara panen yang baik serta penanganan pascapanen yang tepat. Kerusakan sayuran daun (sawi, bayam, kangkung, selada, dll) pada pemanenan adalah daun yang berlobang, tangkai daun patah sehingga mempercepat pelayuan. Kerusakan menjadi lebih besar biasanya disebabkan penanganan pascapanen yang 
tidak baik. Kerusakan sayuran daun terjadi pada berbagai tahapan pra panen hingga pascapanen.

Sebelum dilakukan penanganan pascapanen, telah dilakukan penanganan prapanen yang dilaksanakan di lapangan atau di kebun terhadap komoditas sayuran, termasuk perlakuan yang dilakukan menggunakan senyawa kimia untuk mencegah pembusukan yang disebabkan oleh mikroba terhadap komoditi. Bentuk-bentuk kerusakan lain seperti perkecambahan, kehilangan air, kerusakan dalam penyimpanan, dan serangan insekta dapat diperkecil dengan perlakuan kimia.

Komoditas sayuran harus sesegera mungkin diberi penanganan pasca panen agar kualitasnya tetap terjaga dan memperkecil berbagai bentuk kehilangan. Secara spesifik penanganan pasca panen terhadap sayuran meliputi pencucian, sortasi, dan grading. Untuk mempertahankan kesegaran dan ketegaran sayur dapat dilakukan pengemasan. Penggunaan kemasan plastik sebagai bahan pengemas mempunyai keunggulan dibandingkan dengan bahan kemasan lainnya. Kemasan ini memiliki sifat yang ringan dan mempunyai adaptasi yang tinggi terhadap produk, tidak korosif seperti wadah logam, transparan, kuat, termoplastik dan memiliki permeabilitasnya terhadap uap air, $\mathrm{CO}_{2}$, dan $\mathrm{O}_{2}$.

Kehilangan air selama proses penyimpanan terjadi pada suhu tinggi sehingga perlu diusahakan agar kelembaban dipertahankan relatif tinggi. Kelembaban dapat ditingkatkan dengan penyemprotan lantai penyimpanan dengan air, namun kelembaban tinggi menyebabkan jamur mudah tumbuh termasuk pada dinding ruangan. Perlu dilakukan pembersihan dinding ruangan secara teratur dengan menggunakan larutan natrium hidrokhlorit (khlorin) yang disertai fumigasi dengan menggunakan gas formaldehida. 
Salah satu faktor yang sangat berpengaruh terhadap penurunan mutu sayuran adalah perubahan kadar air. Perubahan kadar air dipengaruhi oleh suhu dan kelembaban ruangan selama penyimpanan.

Sayuran daun yang dikemas dalam plastic wrap akan mengalami peningkatan kadar air selama penyimpanan dan peningkatan pada suhu kamar $\left(25^{\circ} \mathrm{C}\right)$ relatif lebih tinggi dibandingkan dengan suhu rendah. Hal ini terjadi akibat adanya jumlah air metabolit sebagai hasil samping proses respirasi lebih banyak dibandingkan dengan air yang menguap melalui proses transpirasi, sehingga terjadi akumulasi air di antara sel. Untuk memperoleh hasil penyimpanan yang baik, suhu ruang pendingin harus dijaga agar tetap konstan dan tidak berfluktuasi. Hal ini dapat diatasi dengan penggunaan isolator ruangan dan tenaga mesin pendingin yang cukup. Cara penumpukan yang tepat dan sirkulasi udara yang cukup sangat membantu memperkecil variasi suhu.

\section{H. Latihan Soal}

\section{Tugas Individu}

1. Mengapa teknologi pasca panen penting untuk dipelajari? Jelaskan!

2. Jelaskan hubungan antara pengemasan terhadap kualitas produk!

3. Jelaskan hubungan antara penyimpanan terhadap kualitas produk!

4. Jelaskan hubungan antara transportasi terhadap kualitas produk! 


\section{Tugas Kelompok}

Cari jurnal mengenai teknologi pasca panen sayuran daun atau teknologi pasca panen lainnya dan review hasilnya.

\section{Daftar Pustaka}

David, J. H. dan J. C. Kilmanun. 2016. Penanganan Pasca Panen Penyimpanan untuk Komoditas Hortikultura. Prosiding Seminar Nasional Inovasi Teknologi Pertanian. Banjarbaru.

Murtiwulandari, D. T. M. Archery, M. Haloho, R. Kinasih, L. H. S. Tanggara, Y. H. Hulu, K. Agaperesa, N. W. Khristanti, Y. Kristiyanto, S. S. Pamungkas, Y. A. Handoko, dan G. D. Y. Anarki. 2020. Pengaruh suhu penyimpanan terhadap kualitas hasil panen komoditas Brassicaceae. Media Informasi dan Komunikasi Ilmiah Teknologi Pertanian 11(2): 135143.

Nofriati, D. 2013. Teknologi Pascapanen Sayuran Daun. Balai Pengkajian Teknologi Pertanian (BPTP) Jambi. Jambi.

Sudjatha, W. dan N. W. Wisaniyasa. 2017. Fisiologi dan Teknologi Pascapanen (Buah dan sayuran). Buku Ajar. Udayana University Press.

Samad, M. S. 2008. Pengaruh penanganan pasca panen terhadap mutu komoditas hortikultura. Jurnal Sains dan Teknologi Indonesia 8(1):31-36. 
Utama, I. M. S. Kemunduran Produk Hortikultura Segar. Bahan Ajar 3. Prinsip Dasar Penanganan Pascapanen Buah dan sayuran segar.

Yohanis, B. 2008. Penanganan Pasca Panen yang Tepat untuk Mempertahankan Mutu Buah dan Sayur. Penyuluh Pertanian BPP Sesean Suloara Kab. Toraja Utara.

Zam, W., Ilyas, dan Syatrawati. 2019. Penerapan Teknologi Pascapanen untuk Meningkatkan Nilai Jual Cabai di Tanatoraja. Jurnal Dedikasi Masyarakat 2(2): 92-100 


\section{BAB V \\ TEKNOLOGI PENGOLAHAN SAYURAN DAUN I}

Era modern saat ini kesadaran akan pentingnya makanan sehat telah tumbuh dikalangan masyarakat, sehingga dalam pemilihan jenis bahan makanan tidak hanya sekedar enak, namun juga sehat. sayuran yang mudah dibudidaya, harganya sangat terjangkau dan memiliki kandungan gizi tinggi yang dibutuhkan oleh tubuh, namun mempunyai masa simpan yang pendek.

Selama ini pengolahan sayuran hanya diproses dengan pengolahan minimalis sebagai contoh yang sudah sangat umum didapat adalah sayur yang dipotong-potong dan dikombinasikan dengan irisan daging, pasta atau salad dressing, dan siap dikonsumsi. Pengolahan sayuran menjadi bahan makanan lain berpotensi untuk dikembangkan untuk meningkatkan umur simpannya. Selain itu, pengolahan sayuran diharapkan juga mampu meningkatkan nilai ekonomis produk. Beberapa alternatif pengolahannya meliputi blansing (pra pengolahan), penggaraman, fermentasi, pembuatan acar, pengalengan, dan pengeringan.

\section{A. Perlakuan Pra Pengolahan}

Secara umum, pengolahan sayuran dengan tujuan pengawetan dilakukan lebih intensif bila dibandingkan dengan pemasakan biasa, sehingga kehilangan nutrisi, perubahan tekstur, maupun perubahan warna dapat dihindari. Perlakuan pra pengolahan (blansing) dapat menjadi alternatif perlakuan dalam upaya mengurangi penurunan gizi.

Blansing merupakan pemanasan pendahuluan yang umumnya dilakukan pada suhu $75-95^{\circ} \mathrm{C}$ selama 10 menit. 
Blansing merupakan proses pendahuluan dalam pengolahan pascapanen dan merupakan tahap pra proses pengolahan bahan baku. Blansing biasanya dilakukan terhadap sayursayuran dan buah-buahan yang akan dikalengkan atau dikeringkan.

Blansing dilakukan untuk berbagai tujuan, diantaranya yaitu:

1. Membersihkan produk dari partikel-partikel yang melekat (kotoran) yang tidak hilang pada saat proses pencucian.

2. Mengurangi jumlah mikroba awal, proses pemanasan dapat mengurangi jumlah mikroba, terutama mikroba pathogen sehingga dapat memperpanjang umur simpan.

3. Menginaktivasi enzim seperti enzim peroksidase dan katalase yang yang paling tahan terhadap panas.

4. Memperkuat warna dan flavor, beberapa enzim dapat menyebabkan perubahan warna dan flavor sayuran. Proses blansing dapat menginaktifkan enzim-enzim tersebut.

5. Menghilangkan udara yang terdapat dalam rongga-rongga antar sel dalam jaringan bahan sehingga jaringan lentur dan memudahkan dalam proses pengemasan.

Pencoklatan enzimatis merupakan suatu masalah dalam tahapan penyiapan sayuran yang akan diolah lebih lanjut. Sayuran yang telah dipotong, bila dibiarkan lama akan nampak pencoklatan pada jaringannya. Gejala ini ditimbulkan oleh polimer coklat kehitaman yang terbentuk sebagai reaksi antara senyawa polifenol dan oksigen dengan bantuan enzim polifenol oksidase. 
Pada prinsipnya pencegahan pencoklatan enzimatis didasarkan pada usaha inaktivasi enzim polifenol oksidase dan mencegah atau mengurangi kontak dengan udara (oksigen). Inaktivasi enzim dapat dilakukan dengan berbagai cara, salah satunya adalah dengan cara blansing.

Beberapa metode blansing yang umum dilakukan antara lain blansing air (rebus), blansing uap (kukus), dan microwave blansing.

\section{Blansing air}

Water blanching atau blansing air adalah metode blansing dengan menggunakan air panas (direbus). Pada cara ini bahan yang akan di blansing terjadi kontak langsung dengan air panas pada suhu $75^{\circ} \mathrm{C}$ hingga $100^{\circ} \mathrm{C}$. Metode ini sangat sederhana dan murah, namun adanya kontak langsung bahan dengan air dapat menyebabkan hilangnya kandungan komponenkomponen gizi bahan, terutama komponen yang larut dalam air.

2. Blansing uap

Steam blanching atau blansing uap dilakukan dengan cara memanaskan bahan pada kondisi kandungan uap yang tinggi (dikukus). Cara ini dinilai lebih baik dibandingkan dengan metode blansing menggunakan air panas karena memiliki keunggulan dalam menjaga bahan dari kehilangan senyawa fitokimia atau komponen gizi terutama yang larut dalam air. Metode ini paling sering digunakan oleh industri makanan, karena murah dan dapat menjaga lebih banyak mineral dan komponen larut air, metode ini juga efektif untuk meminimalkan pengaruh akibat oksidasi selama proses termal. 
3. Microwave blansing

Microwave blansing dilakukan dengan meletakkan bahan yang akan di blansing dalam microwave. Kelebihan metode ini adalah tidak terdapat limbah air dan pemanasan lebih cepat, sehingga kehilangan nutrisi lebih sedikit.

Blansing sayuran merupakan perlakuan pendahuluan (pretreatment) yang sering dilakukan untuk berbagai pengolahan lanjutan seperti pembekuan, pengalengan, hingga pengeringan. Namun disisi lain, blansing juga dapat berdampak negatif pada kandungan nutrisi sayuran seperti vitamin dan senyawa fenolik relatif tidak stabil jika diberi perlakuan panas. Optimasi proses blansing sangat tergantung pada jenis sayuran, metode blansing, serta kombinasi waktu dan suhu blansing. Ketiga hal tersebut perlu diperhatikan untuk mengurangi atau menekan kehilangan nutrisi produk.

\section{B. Pembekuan}

Pembekuan sayuran pada dasarnya adalah teknik pengolahan setengah jadi. Tujuan utama pengolahan ini adalah untuk menjaga kualitas sayuran selama penyimpanan dan distribusi hingga siap diolah menjadi produk jadi atau siap konsumsi.

Pembekuan sayuran merupakan teknik preservasi yang paling sering dilakukan, dibandingkan dengan teknik pengalengan dan pengeringan. Hal ini disebabkan karena pembekuan dapat memberikan keunggulan dalam menjaga kualitas sayuran beku tetap sama seperti bentuk segarnya jika dilihat dari sisi atribut sensori dan nutrisi.

Teknologi pembekuan ini dapat diterapkan untuk memperpanjang umur simpan sayuran dengan kualitas terjaga seperti bentuk segarnya sehingga distribusinya dapat 
menjadi semakin panjang. Teknik ini juga sangat cocok diterapkan untuk industri horeca (hotel-restoran-catering). Perlakuan pembekuan dapat dilakukan terhadap komoditi tunggal dan juga dapat beberapa produk campuran dari berbagai jenis sayuran.

Pembekuan adalah unit operasi di mana suhu bahan pangan diturunkan hingga di bawah titik bekunya dan sebagian dari air di dalam bahan pangan tersebut berubah bentuknya menjadi kristal-kristal es. Perubahan dari air menjadi es dan konsentrasi larutan pada air yang tidak terbekukan dapat menurunkan aktivitas air (Aw) pada bahan pangan. Efek pengawetan dapat dicapai dengan mengkombinasikan suhu rendah, penurunan Aw, dan pada beberapa bahan pangan, pretreatment seperti blansing.

Perlakuan pendahuluan (blansing) pada proses pembekuan sayuran daun seperti brokoli berpengaruh terhadap tingkat penerimaan konsumen terhadap atribut sensoris brokoli. Berdasarkan hasil penelitian Oktaviani (2011) optimalisasi proses blansing pada pembekuan brokoli menyimpulkan bahwa blansing uap (steam blanching) pada suhu $80{ }^{\circ} \mathrm{C}$ selama 2 menit menghasilkan brokoli yang paling disukai oleh konsumen.

Secara umum proses pembekuan sayuran daun meliputi beberapa tahapan yaitu persiapan (pencucian, pengupasan, dan pemotongan), blansing, dan pembekuan (Gambar 1). 


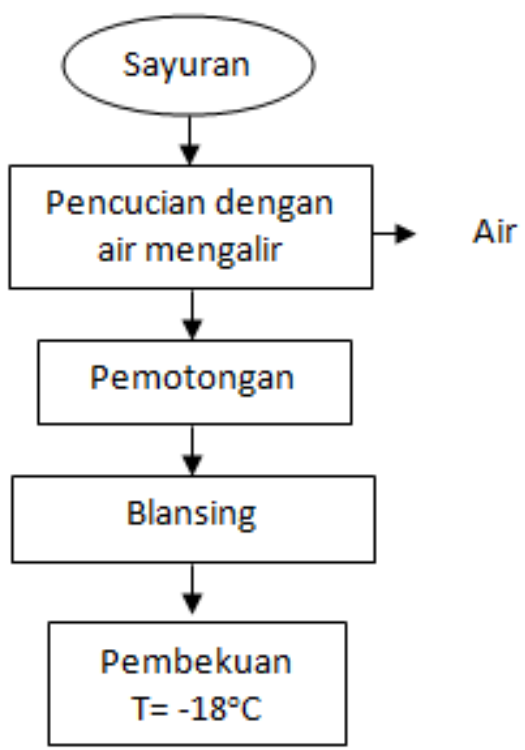

Gambar 1 Diagram Alir Pembekuan Sayuran

(Koswara, 2009)

Teknik pembekuan yang paling sering digunakan yaitu quick-freezing (pembekuan cepat) dan blast-freezing (pembekuan dengan suhu sangat rendah). Semakin cepat proses pembekuan, semakin bagus mutu produk yang dihasilkan, terutama setelah di thawing (pencairan) kembali. Perlakuan pendahuluan dengan bahan-bahan tambahan seperti alkali metabisulfit, magnesium hidroksida dapat juga memperbaiki mutu produk dari komoditi-komoditi tertentu.

\section{Pengalengan}

Pengalengan merupakan cara pengolahan untuk mendapatkan produk awet yang tahan lama dengan perlakuan panas. Selain pengalengan suatu jenis komoditi di 
dalam larutan garam, sayuran dapat diolah bersama dengan sayuran lain menjadi suatu produk siap makan.

Prinsip pengalengan ialah menempatkan produk dalam wadah yang tahan panas serta dapat ditutup rapat, kemudian diberi perlakuan pemanasan pada temperatur tertentu dalam jangka waktu tertentu pula dengan tujuan membunuh mikroba yang merugikan.

Tahap pengalengan kubis meliputi: persiapan (pencucian, penaburan garam, pembungkusan dengan kain saring, blansing dengan cara perebusan selama 10 menit), pengisian ke wadah, penambahan larutan garam $2 \%$ yang telah disaring terlebih dahulu sampai $1 \mathrm{~cm}$ di bawah permukaan, penghilangan udara dengan cara pemanasan dalam air mendidih, segera dilanjutkan dengan "sealing" (penutupan wadah), dan terakhir ialah sterilisasi dalam retort pada suhu $116{ }^{\circ} \mathrm{C}$ selama $30-60$ menit tergantung dari wadah yang digunakan.

\section{Pengeringan (Dehidrasi)}

Produk sayuran kering banyak digunakan akhir-akhir ini, terutama pada produk-produk instant. Cara pengeringan yang terbaik ialah dengan menggunakan freeze dryer, karena dihasilkan produk kering yang mendekati komoditi segar bila direhidrasi (dibasahkan) kembali. Hanya saja, untuk cara ini masih diperlukan peralatan dan biaya operasional yang relatif tinggi. Produk freeze drying memang lebih diarahkan untuk produk ekspor.

Cara lain untuk pengeringan ialah dengan menggunakan sinar matahari, hot airdryer (pengeringan dengan udara panas), far infra red-dryer (pengeringan dengan sinar infra red jauh). 
Tahap pengeringan pada sayuran yang umumnya dilakukan ialah: persiapan (pencucian, pengupasan dan pemotongan), blansing, sulfitasi (perendaman dalam larutan sulfit) dan terakhir ialah proses pengeringan. Pada kubis tidak dilakukan pengupasan, akan tetapi setelah pencucian dilakukan pembuangan hati (bagian tengah kubis yang keras) lalu dilanjutkan dengan perajangan memanjang selebar 4-8 $\mathrm{cm}$.

Tahap selanjutnya adalah perlakuan blansing dalam air selama 5 - 6 menit, kemudian dilakukan sulfitasi dengan cara merendam kubis dalam larutan 0,25\% kalium metabisulfit selama 10 menit dengan perbandingan bahan dan larutan sebagai 1:2.

\section{E. Ringkasan}

Kesadaran akan pentingnya makanan sehat telah tumbuh dikalangan masyarakat, sehingga dalam pemilihan jenis bahan makanan tidak hanya sekedar enak, namun juga sehat. Selama ini pengolahan sayuran hanya diproses dengan pengolahan minimalis misalnya dipotong-potong dan dikombinasikan dengan irisan daging, pasta atau salad dressing dan siap dikonsumsi. Pengolahan sayuran diharapkan mampu meningkatkan nilai ekonomis produk serta memperpanjang umur simpan produk. Beberapa alternatif pengolahannya meliputi blansing (pra pengolahan), penggaraman, fermentasi, pembuatan acar, pengalengan, dan pengeringan.

Secara umum, pengolahan sayuran untuk maksud pengawetan dilakukan lebih intensif bila dibandingkan dengan pemasakan biasa, sehingga kehilangan nutrisi, perubahan tekstur, maupun perubahan warna dapat dihindari. Perlakuan pra pengolahan (blansing) dapat menjadi 
alternatif perlakuan dalam upaya mengurangi penurunan gizi. Blansing sayuran merupakan perlakuan pendahuluan (pretreatment) yang sering dilakukan untuk berbagai pengolahan lanjutan seperti pembekuan, pengalengan, hingga pengeringan. Namun disisi lain, blansing juga dapat berdampak negatif pada kandungan nutrisi sayuran seperti vitamin dan senyawa fenolik relatif tidak stabil jika diberi perlakuan panas. Optimasi proses blansing sangat tergantung pada jenis sayuran, metode blansing, serta kombinasi waktu dan suhu blansing. Ketiga hal tersebut perlu diperhatikan untuk mengurangi atau menekan kehilangan nutrisi produk.

F. Latihan Soal

\section{Tugas Individu}

1. Mengapa sayur perlu diolah? Jelaskan!

2. Jelaskan perlakuan pra pengolahan pada sayuran daun!

3. Jelaskan hubungan antara proses pengolahan terhadap kualitas produk!

\section{Tugas Kelompok}

Cari jurnal mengenai pengolahan sayuran daun, presentasikan metode pembuatan, hasil dan kesimpulannya!

\section{Daftar Pustaka}

Alifah, S., A. Nurfida, dan A. Hermawan. 2019. Pengolahan Sawi Hijau Menjadi Mie Hijau yang Memiliki Nilai Ekonomis Tinggi di Desa Sukamanis Kecamatan Kadudampit Kabupaten Sukabumi. Journal of Empowerment Community I (2): 52-58. 
Asgar A., dan D. Musaddad. 2006. Optimalisasi Cara, Suhu, dan Lama Blansing Sebelum Pengeringan Pada Wortel. Jurnal Hort. XVI (3): 245-252.

Ayu, D. C. dan S. S. Yuwono. 2014. Pengaruh Suhu Blansing dan Lama Perendaman Terhadap Sifat Fisik Kimia Tepung Kimpul (Xanthosoma sagittifolium). Jurnal Pangan dan Agroindustri II (2): 110-120.

Duvernay, M. 2014. Comparison of Water and Microwave Blanching of Mangoes and Sensory Evaluation dalam https://zenodo.org diakses Tanggal 21 Januari 2020.

Koswara, S. 2009. Teknologi Pengolahan Sayuran dan Buahbuahan (Teori dan Praktek). eBookpangan.com.

Oktaviani, A. L. 2011. Studi Optimalisasi Pre-Treatment Blanching dan Metode Pembekuan pada Brokoli (Brassica oleracea L. var. Italica). Skripsi. Universitas Katolik Soegijapranata. Semarang.

Pardede, E. 2009. Buah dan Sayur Olahan secara Minimalis. Jurnal VISI XVII (3): 245-254.

Wulansari, A. dan N. Sekar. 2017. Blanching. Laporan Praktikum. Universitas Jendral Soedirman. Purwokerto 


\section{$B A B$ VI \\ TEKNOLOGI PENGOLAHAN SAYURAN DAUN II}

A. Fermentasi

Fermentasi merupakan cara yang tertua disamping pengeringan yang dipraktekkan manusia untuk tujuan pengawetan dan pengolahan makanan. Makanan terfermentasi merupakan hasil aktifitas berbagai spesies bakteri, khamir, dan kapang. Proses katabolisme memegang peranan penting dalam siklus kehidupan mikroorganisme. Kemampuan mikroba dalam merubah karbohidrat melalui proses katabolisme tersebut menjadi asam laktat, asam asetat alkohol dan senyawa-senyawa lain, menyebabkan mikroba menjadi demikian penting bagi manusia untuk menghasilkan makanan awet dan bergizi tinggi. Berbagai hasil penelitian telah berhasil mengungkapkan bahwa melalui fermentasi, bahan-bahan makanan akan mengalami perubahan fisik dan kimia yang menguntungkan seperti terbentuknya flavor dan aroma yang disukai.

Apabila sejumlah tertentu garam kering ditambahkan ke dalam sayur-sayuran, setelah beberapa lama, akan terbentuk larutan garam yang jenuh, selama pemisahan garam yang dilakukan dengan perendaman dalam air, sayursayuran tersebut akan melalui beberapa fase yang mendukung berlangsungnya fermentasi asam laktat sehingga membentuk cita rasa baru. Cita rasa asam ini mengimbangi sebagian cita rasa asin yang berlebihan.

Aplikasi dari ilmu pengetahuan pada penggaraman dan penamaan bakteri dan khamir yang terdapat dalam fermentasi bahan-bahan sayuran baru mulai pada awal tahun 1900. Perbaikan-perbaikan dalam hal teknik produksi dan 
pengembangan galur-galur sayuran berkualitas superior dan tahan terhadap penyakit telah memegang peranan yang sangat penting dalam mensuplai bahan-bahan sayuran dengan kuantitas dan kualitas yang memuaskan untuk fermentasi. Perbaikan-perbaikan yang nyata dalam fermentasi sayur-sayuran dimulai dengan pengembanganpengembangan dalam bidang mikrobiologi sekitar 100 tahun yang lalu. Kulminasi dari semua hal-hal ini sampai pada kesimpulan bahwa lebih dari satu spesies bakteri asam laktat yang berperan dalam fermentasi sayur-sayuran.

Pertumbuhan dan aktivitas fermentasi dari spesiesspesie ini dipengaruhi oleh faktor-faktor lingkungan terutama kadar garam dan temperatur. Berkat hasil penelitianpenelitian, sebagian besar sifat-sifat alami dari fermentasi asam laktat pada sayur-sayuran dan buah-buah pangan lainnya serta perubahan-perubahan mikrobiologi, fisik, dan kimia yang terjadi selama fermentasi telah dapat diketahui. Secara umum dapat diambil kesimpulan bahwa fermentasi asam laktat menghasilkan keuntungan-keuntungan sebagai berikut:

1. Menyebabkan bahan pangan menjadi resisten terhadap pembusukan mikrobiologi dan pembentukan racun-racun makanan.

2. Menyebabkan bahan pangan menjadi kurang ideal sebagai media perpindahan mikrobamikroba pathogen.

3. Menyebabkan bahan pangan mengalami penurunan nilai gizi.

4. Memodifikasi cita-rasa orisinil bahan pangan menjadi lebih merangsang selera makan dan kadang-kadang memperbaiki nilai gizi. 
Hampir semua jenis sayur-sayuran, termasuk sayuran buah seperti, ketimun, tomat, dan zaitun dapat difermentasi oleh bakteri asam laktat. Semua jenis sayur-sayuran mengandung gula dan komponen-kompoenen nutrisi lainnya yang cukup sebagai substrat untuk pertumbuhan bakteri asam laktat dan mikroba-mikroba lainnya. Namun demikian, sayur-sayuran yang paling populer digunakan untuk fermentasi asam laktat adalah kubis untuk pembuatan sauerkraut serta ketimun dan zaitun untuk pembuatan pikel. Dalam jumlah yang lebih kecil, berbagai jenis sayur-sayuran lain seperti wortel, kembang kol, seledri, okra, lada, bawang, dan tomat hijau juga difermentasi, khususnya untuk pembuatan pikel campuran.

\section{B. Sauerkraut}

Sauerkraut atau suerkhol adalah terminologi yang berasal dari jerman yang telah populer digunakan secara International sebagai nama "kubis asam, yaitu hasil fermentasi asam laktat dari rajangan putih dengan panjang sekitar $20 \mathrm{~cm}$ dan lebar sekitar $2 \mathrm{~mm}$ sampai dengan $5 \mathrm{~mm}$. Walaupun namanya menggunakan terminologi Jerman, pendapat yang mengatakan bahwa produk ini berasal dari Jerman tidak dibenarkan, oleh karena orang-orang Jerman adalah pengembara ketika pertama kali mereka mengenal produk-produk ini dari orang Romawi sekitar permulaan era kristen.

Kubis (Brassica oleracea) adalah satu jenis tanaman yang sudah sangat lama dikenal dan digunakan manusia untuk berbagai keperluan. Gambar-gambar dan figura-figura dari Mesir kuno melukiskan meletakkan kubis dialtar candi sebagai pemberian atau anugrah yang terhormat dari Tuhan. Dokter-dokter Yunani dan Romawi menggunakan kubis sebagai obat untuk berbagai jenis penyakit dan oleh karena 
itu, kubis adalah sayuran yang umum ditanam dikebun-kebun milik orang Yunani dan Romawi. Diskripsi-diskripsi kuno yang menunjukkan terdapat varitas kubis yang berkepala putih dan padat yang merupakan indikasi bahwa kubis sudah sangat lama didomestikan sehingga telah mengatasi perubahan-perubahan yang eksentif dari tipe-tipe yang liar menjadi tipe-tipe yang dibudidayakan.

Kubis adalah suatu jenis tanaman beriklim sedang yang berasal dari berbagai tempat didaratan Eropa. Namun demikian, penggunaan kubis sebagai suatu tanaman sayuran dengan teknik budidaya di daratan Eropa bagian utara dipelopori oleh bangsa Romawi. Kubis berkepala putih, besar dan padatan olahan varitas kubis yang paling banyak ditanam didaerah-daerah beriklim sedang didaratan Eropa bagian utara.

Dalam diet manusia, kubis selalu mempunyai kedudukan yang mana perananya sebagai bahan tambahan untuk membuat bahan makanan lain lebih disukai dan lebih mudah dicerna lebih menonjol dari pada nilai gizinya sendiri. Selain itu, peranan kubis sebagai obat juga cukup menonjol.

Sauerkraut yang dibuat pada jaman dahulu sangat berbeda dengan sauerkraut yang dihasilkan sekarang, pada mulanya, sauerkraut dibuat hanya dengan merabuk atau membumbui daun kubis dengan anggur asam atau vinegar. Kemudian pembuatan sauerkraut berkembang, daun kubis dipatahkan dan dipotong menjadi potongan-potongan kecil, lalu dikemas dalam suatu wadah kemudian ditambahkan larutan perendam, yaitu Verjuis (sari perasaan dari apel atau anggur mentah), anggur asam atau vinegar. Metoda ini lambat laun berkembang lagi dimana larutan-larutan asam diganti dengan garam dan fermentasi spontan pun mulai berlangsung. 
Sauerkraut dapat dibuat secara sederhana dengan menambahkan garam kerajangan kubis, lalu dikemas dalam suatu wadah didiamkan untuk berfermentasi dalam beberapa minggu akan dihasilkan produk fermentasi yang bisa dimakan. Apabila dibuat dengan cermat dengan jumlah garam dan temperature yang tepat, dibalur garam dengan sempurna dan dikemas dengan rapat, maka produk akhir yang dihasilkan akan bagus.

Metoda-metoda yang digunakan untuk pembuatan sauerkraut dewasa ini telah berkembang dengan meningkatnya pengetahuan tentang hal-hal yang berlangsung dalam fermentasi. Sampai akhir-akhir ini, pembuatan sauerkraut masih berdasarkan naluri yang dalam banyak hal menyebabkan sauerkraut bermutu inferior atau busuk. Pada tahun 1900, studi-studi baru mulai dirancang untuk lebih banyak mempelajari proses dan pengaruh faktorfaktor lingkungan untuk mengembangkan metoda-metoda yang di dalam batas-batas tertentu dapat menstandarisasi mutu produk sauerkraut yang dihasilkan.

Varietas-varietas kubis yang digunakan untuk pembuatan sauerkraut adalah varietas-varietas yang dapat tumbuh dengan baik didaerah-daerah sentra produksi. Akan tetapi, kemudian dikembangkan varitas-varitas kubis yang khusus untuk pembuatan sauerkraut. Faktor-faktor yang digunakan sebagai dasar pengembangan varitas-varitas kubis dalam lima puluh tahun terakhir ini adalah rendemen, ketahanan terhadap penyakit dan penggunaan alat-alat pemanen mekanis. Dengan demikian sebagian besar varitasvaritas baru yang telah beradaptasi dengan baik dengan teknik pemanen mekanis serta mempunyai kandungan padatan terlalu lebih tinggi dan kandungan air lebih tinggi dan kandungan lebih rendah sehingga mengurangi limbah 
cair pabrik. Varitas kubis dipilih untuk pembuatan sauerkraut yang berkualitas superior adalah kubis yang berkepala putih, padat, manis, dan mempunyai cita-rasa yang ringan.

Pada mulanya, pembuatan sauerkraut hanya dilakukan dirumah tangga sebagai usaha untuk menyelamatkan, akan busuk sebelum digunakan. Dewasa ini, produksi sauerkraut secara komersial telah menjadi suatu industri pangan yang penting walaupun sejumlah tertentu sauerkraut masih diproduksi dirumah tangga, khususnya didaerah-daerah pinggiran kota dan pedesaan dimana masih terdapat kebun sayur perkarangan.

Negara-negara produsen sauerkraut yang paling terkenal dewasa ini adalah Jerman dan Amerika Serikat serta Belanda, Perancis dan Canada. Produksi sauerkraut di Amerika Serikat lebih dari dua kali banyak dari pada produksi sauerkraut di Jerman, akan tetapi, konsumsi sauerkraut di Jerman dua kali dari pada konsumsi sauerkraut sangat popular, konsumsi oleh seluruh lapisan masyarakat dengan cara dimakan segar atau dimasak dengan daging, sosis atau makan-makanan lainnya. Oleh karena itu, kedua negara ini juga mempunyai standart untuk sauerkraut.

Di Jerman, sauerkraut harus mengandung minimum $7,5 \%$ asam laktat dengan $\mathrm{pH}$ maksimum 4,1; larutan garam yang dapat tertampung harus sebanyak sekitar 10\% dari berat total sauerkraut dengan kadar garam berkisar antara 0,7\% sampai dengan 3,0\%. Departemen Pertanian Amerika Serikat menentukan kadar garam produk akhir sauerkraut harus berkisar antara 1,3\% sampai dengan 2,5\% dan jumlah garam yang dianjurkan untuk digunakan pada awal penggaraman adalah $2,25 \% \mathrm{~B} / \mathrm{B}$. 
Garam memegang utama dalam pembuatan sauerkraut dan oleh karena itu, konsentrasi garam yang digunakan harus dikontrol dengan teliti. Menurut standar yang telah ditetapkan, konsentrasi garam yang digunakan tidak boleh kurang dari $2 \%$ dan tidak boleh lebih dari 35 . Akan tetapi, pembuatan sauerkraut pada umumnya menggunakan garam pada konsentrasi yang berkisar antara $2,25 \%$ sampai dengan 2,5\%. Garam yang ditambah harus disebarkan secara merata keseluruh massa rajangan.

Konsentrasi garam dalam larutan garam yang baru terbentuk meningkatkan berat jenis larutan garam tersebut sehingga rajang-rajangan kubisnya didalamnya cenderung mengapung. Oleh karena itu, kantong terbuka yang terbentuk diatas rajang-rajangan kubis dalam bak atau tangki fermentasi haruis diisi dengan air atau lebih disukai larutan garam sebagai pemberat atau menekan rajangan-rajangan kubis kedalam larutan garam sampai permukaan rajanganrajangan kubis yang berada pada bagian atas terendam oleh larutan garam. Apabila rajang-rajangan kubis tidak terendam dengan sempurna dalam larutan garam, rajangan-rajangan kubis tersebut akan mengalami perubahan warna (diskolorasi) yang disertai dengan perubahan cita rasa yang tidak diinginkan.

Selain dari sayur-sayuran seperti yang telah disebutkan diatas (kubis dan mentimun), berbagai jenis sayur-sayuran lainnya juga digunakan untuk fermentasi. Terdapat kemungkinan bahwa pada jaman dahulu telah banyak sayur-sayuran yang diawetkan dengan perendaman dalam larutan garam dan fermentasi. Sayur-sayuran yang disebutkan dalam kepustakaan telah digunakan untuk fermentasi termasuk wortel, bunga kol, seledri, jagung, tomat hijau, bawang, cabe, selada, lobak, buncis, kapri, dan 
lain-lain. Sebagian dari produk fermentasi sayur-sayuran ini diperdagangkan dengan cara eceran seperti bunga kol, bawang, wortel, dan seledri. Selain itu beberapa produk fermentasi sayur-sayuran ini dibuat hanya dirumah tangga atau paling banyak untuk konsumsi regional.

Teknik penggaraman untuk pengawetan berbagi jenis sayur-sayuran dilakukan dengan penggaraman kering atau perendaman dalam larutan garam. Dalam hal ini konsentrasi garam yang digunakan bervariasi $10^{\circ}$ salometer sampai dengan $60^{\circ}$ salometer atau lebih. Pada produk yang dibuat dengan menggunakan fermentasi asam laktat, sedangkan pada konsentrasi garam yang lebih tinggi sampai dengan $60^{\circ}$ salometer atau lebih, asam laktat tidak dapat lagi berbentuk, akan tetapi asam asetat mungkin ditemukan apabila terdapat khamir pembentuk asam. Pengawetan sayur-sayuran daun lebih banyak dilakukan dengan penggaraman kering seperti pada pembuatan sauerkraut, sedangkan pengawetan sayursayuran buah, sayur-sayuran umbi dan sayur-sayuran berbiji lebih banyak dilakukan dengan perendaman dalam larutan garam.

\section{Pembuatan Acar (Pickles)}

Pikel sayuran merupakan bahan pangan yang diawetkan dalam vinegar (larutan cuka), baik dengan maupun tanpa penambahan rempah-rempah. Pikel ini dapat dibuat tanpa fermentasi, setengah terfermentasi, atau terfermentasi lengkap. Ada beberapa jenis pikel yang umumnya dapat digolongkan sebagai "Dills pickles", "Sour pickles" dan "Sweet pickles". Masing-masing pikel ini mempunyai ciri-ciri serta cita rasa yang agak berlainan.

Pemikelan pada kubis dapat dilakukan dengan merajang kubis, pengasaman dengan asam sitrat, dan/atau 
larutan cuka sampai mencapai 0,5 s/d 0,7 \% asam dihitung sebagai asam laktat, lalu dilakukan penambahan gula secukupnya (5 - 10\% gula), lalu blansing dengan cara memanaskan sampai suhu $75-77^{\circ} \mathrm{C}$ selama beberapa menit. Perlakuan selanjutnya yang umum dilakukan ialah menempatkan pada wadah gelas dengan cara: pertama-tama mengisikan sedikit larutan terlebih dahulu, baru kemudian mengisikan kubis yang telah diblansing tadi, selanjutnya dipenuhi kembali dengan larutan sampai $1 \mathrm{~cm}$ di bawah permukaan (sisakan ruang kosong untuk head space). Selesai pengisian, tutup wadah lalu pasteurisasi dengan cara memanaskan sampai suhu pada tengah wadah mencapai 71 ${ }^{\circ} \mathrm{C}$ selama 15 menit atau $74{ }^{\circ} \mathrm{C}$ selama 20 menit,dan dikeringkan dengan cepat sampai suhu mencapai di bawah $37^{\circ} \mathrm{C}$.

Konsumsi pikel sayuran di dalam negeri memang sangat terbatas, tetapi di luar negeri seperti Korea dalam bentuk "kimchi", Jepang dalam bentuk "tsukemono", Eropa dalam bentuk "sauerkraut" merupakan konsumsi sehari-hari yang tidak bisa diabaikan jumlahnya. Oleh karena itu, pembuatan kubis pikel setengah jadi sebagai pensuplai bahan baku ke negara-negara tersebut dapat diharapkan menjadi produk ekspor non migas yang mempunyai prospek baik.

Pikel setengah jadi dapat disiapkan dengan cara merendam lembaran-lembaran daun kubis yang telah dicuci bersih terlebih dahulu ke dalam larutan garam dengan konsentrasi tertentu sesuai dengan keasinan dan keawetan yang dikehendaki. Sebelum direndam, dapat juga dilakukan blansing (pencelupan dalam air atau uap panas), untuk menginaktifkan enzim-enzim. Penggaraman dapat juga dilakukan dengan cara pelumuran saja. 


\section{Ringkasan}

Fermentasi merupakan cara yang tertua disamping pengeringan yang dipraktekkan manusia untuk tujuan pengawetan dan pengolahan makanan. Makanan terfermentasi merupakan hasil aktifitas berbagai spesies bakteri, khamir, dan kapang. Proses katabolisme memegang peranan penting dalam siklus kehidupan mikroorganisme. Kemampuan mikroba dalam merubah karbohidrat melalui proses katabolisme tersebut menjadi asam laktat, asam asetat alkogol dan senyawa-senyawa lain, menyebabkan mikroba menjadi demikian penting bagi manusia untuk menghasilkan makanan awet dan bergizi tinggi. Berbagai hasil penelitian telah berhasil mengungkapkan bahwa melalui fermentasi, bahan-bahan makanan akan mengalami perubahan fisik dan kimia yang menguntungkan seperti terbentuknya flavor dan aroma yang disukai.

Pertumbuhan dan aktivitas fermentasi dari spesiesspesie ini dipengaruhi oleh faktor-faktor lingkungan terutama kadar garam dan temperatur. Berkat hasil penelitianpenelitian, sebagian besar sifat-sifat alami dari fermentasi asam laktat pada sayur-sayuran dan buah-buah pangan lainnya serta perubahan-perubahan mikrobiologi, fisik, dan kimia yang terjadi selama fermentasi telah dapat diketahui. Secara umum dapat diambil kesimpulan bahwa fermentasi asam laktat menghasilkan keuntungan-keuntungan sebagai berikut: 1) Menyebabkan bahan pangan menjadi resisten terhadap pembusukan mikrobiologi dan pembentukan racunracun makanan; 2) Menyebabkan bahan pangan menjadi kurang ideal sebagai media perpindahan mikroba-mikroba pathogen; 3) Menyebabkan bahan pangan mengalami penurunan nilai gizi; 4) Memodifikasi cita-rasa orisinil bahan pangan menjadi lebih merangsang selera makan dan kadangkadang memperbaiki nilai gizi. 


\section{E. Latihan Soal}

\section{Tugas Individu}

1. Jelaskan manfaat fermentasi pada proses pengolahan sayuran daun!

2. Sebutkan dan jelaskan perubahan-perubahan yang terjadi selama proses fermentasi!

3. Sebutkan beberapa jenis sayuran daun yang dapat diolah dengan cara fermentasi!

\section{Tugas Kelompok}

Cari jurnal mengenai pengolahan sayuran daun secara fermentasi, presentasikan metode pembuatan, hasil dan kesimpulannya! 


\section{BAB VII \\ BERBAGAI JENIS OLAHAN SAYURAN DAUN}

A. Kubis

Diantara sayuran jenis daun, kubis termasuk yang paling tahan lama. Walau demikian, seperti halnya produk hortikultura lainnya, masih tetap sangat terbatas masa simpannya. Penambahan daya simpan komoditi segar lebih ditekankan pada cara pengemasan dan cara transportasinya. Selain itu di luar negeri dikenal juga perlakuan dengan iradiasi. Dalam hal pengolahan, sayuran daun seperti kubis memang agak sulit untuk diolah walau demikian bukan berarti sama sekali tidak dapat diolah. Alternatif pengolahannya meliputi: dikeringkan, di buat pikel (produk jadi atau setengah jadi), dibekukan, dikalengkan (siap makan) (Gambar 2).

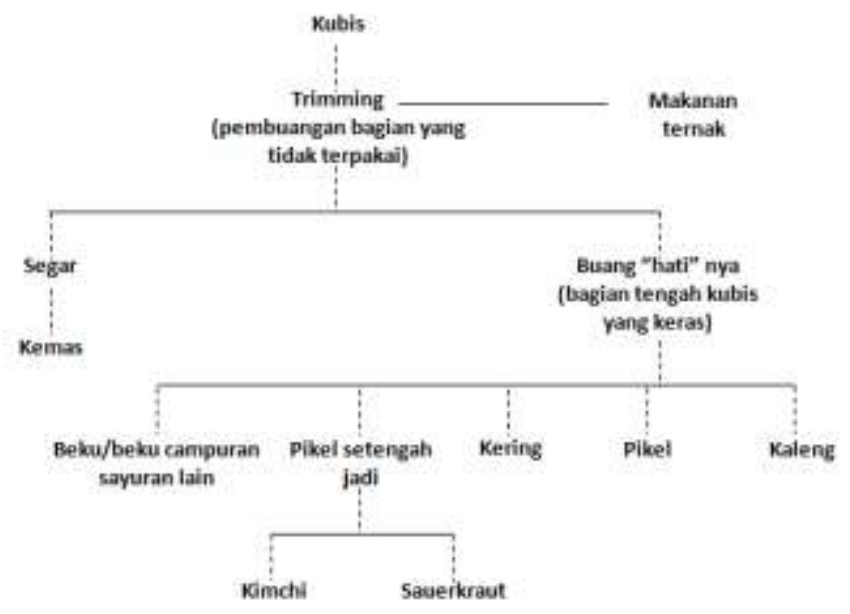

Gambar 2. Bentuk-bentuk Olahan Kubis 
1. Penanganan segar

Pemanenan dan penanganan hasil penen perlu dilakukan dengan cermat dan hati-hati. Perlakuan yang kasar akan menimbulkan memar dan mempermudah kebusukan. Pengemasan yang umum dilakukan dengan menggunakan kemasan perforated polypropylene (polipropilen berpori) untuk tingkat eceran dan untuk borongan/grosir, seperti halnya Jepang, dapat menggunakan plastic netbags (kantong jaring). Akhir-akhir dipopulerkan sistem MAC (Modified Atmosphere Container) dan CAP (Control Atmosphere Packaging) yang memungkinkan produk segar tetap dalam keadaan segar selama pengiriman jarak jauh. Penanganan dalam suhu rendah pun (jangan sampai beku) dapat memperpanjang kesegaran komoditi dan mengurangi penyusutan berat.

2. Pembekuan

Pembekuan merupakan cara pengawetan produk dalam menggunakan suhu rendah (Gambar 3). Pembekuan dapat mematikan beberapa jenis mikroba yang merugikan bahkan kadang sampai lebih dari 90 \% yang dapat terhilangkan. Produk jadinya pun tetap memerlukan perlakuan pendinginan. Penanganan cara ini agak merepotkan serta memerlukan biaya operasional yang relatif mahal.

Perlakuan pembekuan dapat dilakukan terhadap komoditi tunggal dan juga dapat beberapa produk campuran dari berbagai jenis sayuran yang siap digunakan. Produk yang terakhir ini banyak digemari akhir-akhir ini karena praktis. 


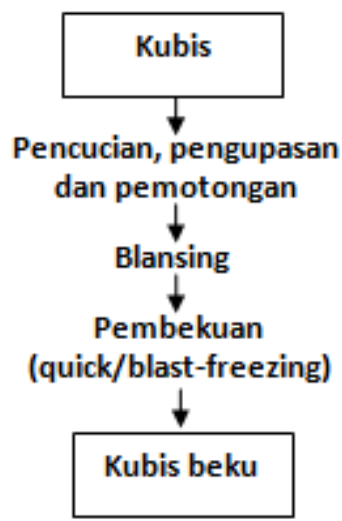

Gambar 3. Diagram Alir Pembekuan Kubis

3. Pikel setengah jadi

Konsumsi pikel sayuran di dalam negeri memang sangat terbatas, tetapi di luar negeri seperti Korea dalam bentuk kimchi (Gambar 4), Jepang dalam bentuk tsukemono dan Eropa dalam bentuk sauerkraut (Gambar 5) merupakan konsumsi sehari-hari yang tidak bisa diabaikan jumlahnya. Oleh karena itu, pembuatan kubis pikel setengah jadi sebagai pensuplai bahan baku ke negara-negara tersebut dapat diharapkan menjadi produk ekspor non migas yang mempunyai prospek baik. Pikel setengah jadi dapat disiapkan dengan cara merendam lembaran-lembaran daun kubis yang telah dicuci bersih terlebih dahulu ke dalam larutan garam dengan konsentrasi tertentu sesuai dengan keasinan dan keawetan yang dikehendaki. Sebelum direndam, dapat juga dilakukan blansing (pencelupan dalam air atau uap panas), untuk menginaktifkan enzim-enzim. Penggaraman dapat juga dilakukan dengan cara pelumuran saja. 


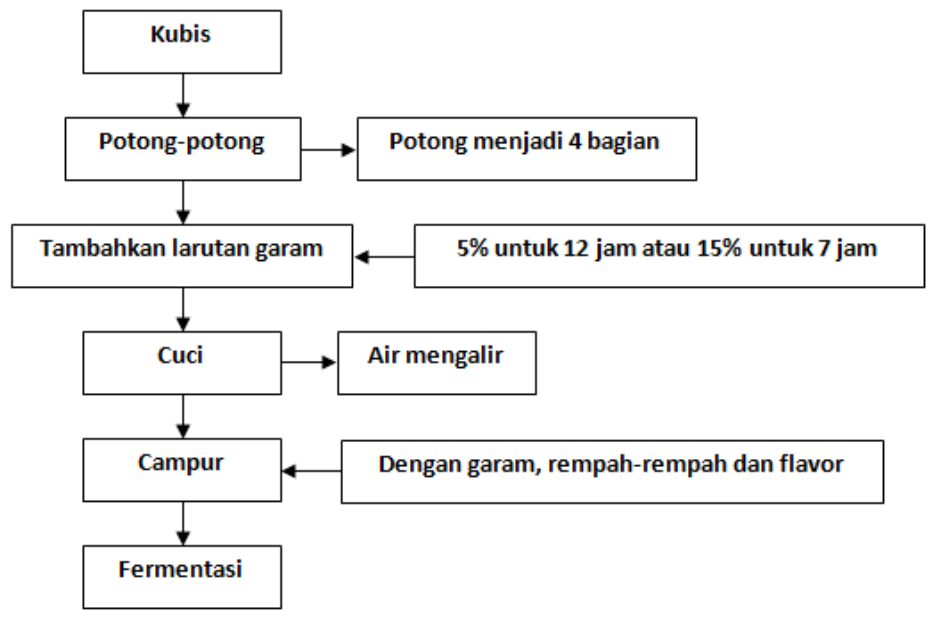

Gambar 4. Diagram Alir Pembuatan Kimchi 


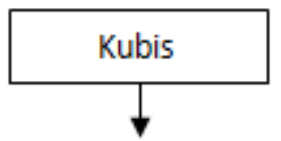

Pisahkan daun yang berwarna hijau, rusak dan kotor

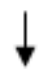

Buang inti kubis

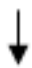

Perajangan

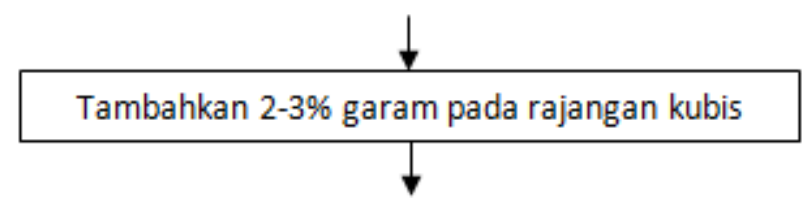

Letakkan rajangan kubis pada dalam toples

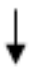

Tutup toples dengan rapat (kedap udara)

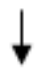

Fermentasi suhu $20-25^{\circ} \mathrm{C}$ selama 8 hari

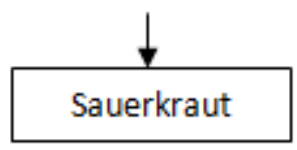

Gambar 5. Diagram Alir Pembuatan Sauerkraut (Diamante, 2007; Sasitorn, 2007)

4. Pengeringan

Produk sayuran kering banyak digunakan akhirakhir ini, terutama pada produk-produk instant. Cara pengeringan yang terbaik ialah dengan menggunakan freeze dryer, karena dihasilkan 
produk kering yang mendekati komoditi segar bila direhidrasi (dibasahkan) kembali. Hanya saja, untuk cara ini masih diperlukan peralatan dan biaya operasional yang relatif tinggi. Produk freeze drying memang lebih diarahkan untuk produk ekspor. Cara lain untuk pengeringan ialah dengan menggunakan sinar matahari, hot airdryer (pengeringan dengan udara panas), far infra reddrier (pengeringan dengan sinar infra red jauh).

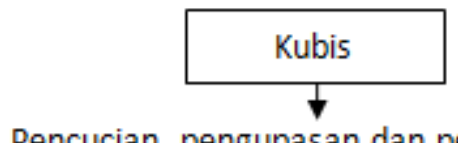

\section{Pencucian, pengupasan dan pemotongan}

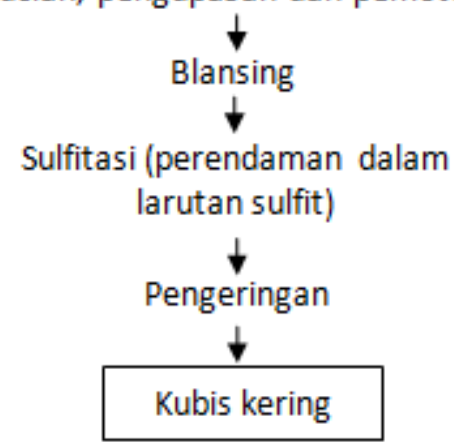

Gambar 6. Diagram Alir Proses Pengeringan Kubis (Koswara, 2009)

5. Pikel jadi

Pikel sayuran yang diawetkan dalam vinegar (larutan cuka), baik dengan maupun tanpa penambahan rempah-rempah (Gambar 7). Pikel ini dapat tanpa fermentasi, setengah terfermentasi, atau terfermentasi lengkap. Ada beberapa jenis pikel yang umumnya dapat digolongkan sebagai Dills pickles, Sour pickles, dan 
Sweet pickles. Masing-masing pikel ini mempunyai ciri-ciri serta cita rasa yang agak berlainan.

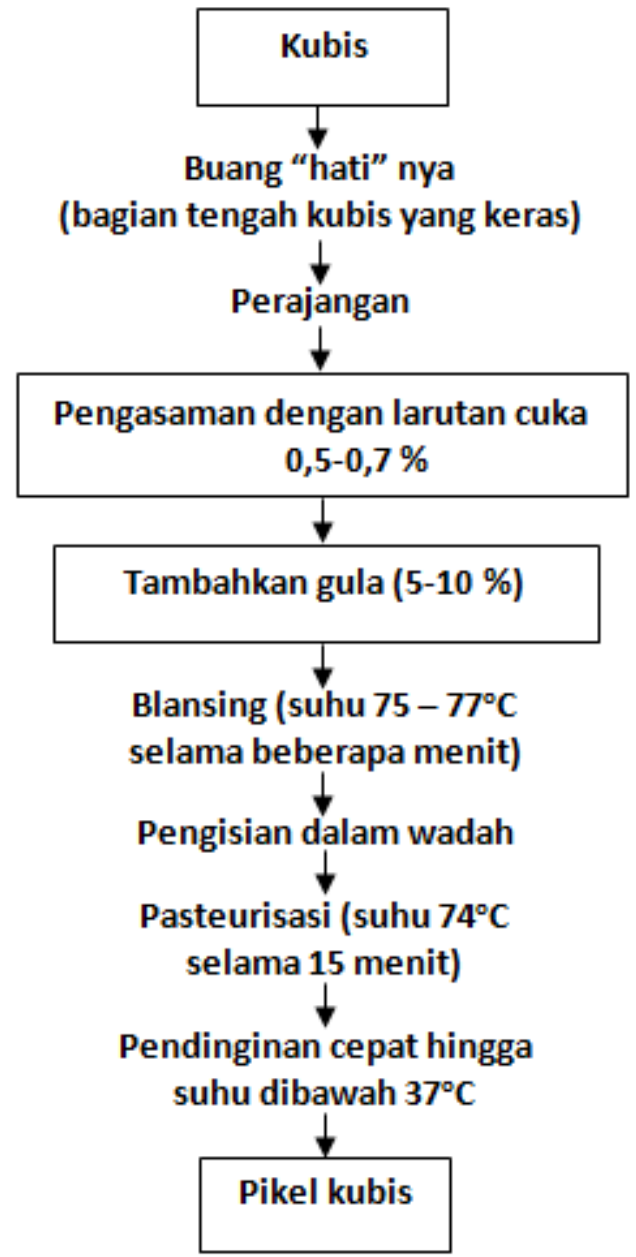

Gambar 7. Diagram Alir Pemikelan Kubis (Koswara, 2009) 


\section{Pengalengan}

Pengalengan merupakan cara pengolahan untuk mendapatkan produk awet yang tahan lama dengan perlakuan panas (Gambar 8). Selain pengalengan suatu jenis komoditi di dalam larutan garam, sayuran dapat diolah bersama dengan sayuran lain menjadi suatu produk siap makan. Prinsip pengalengan ialah menempatkan produk dalam wadah yang tahan panas serta dapat ditutup rapat, kemudian diberi perlakuan pemanasan pada temperatur tertentu dalam jangka waktu tertentu pula dengan tujuan membunuh mikroba yang merugikan.

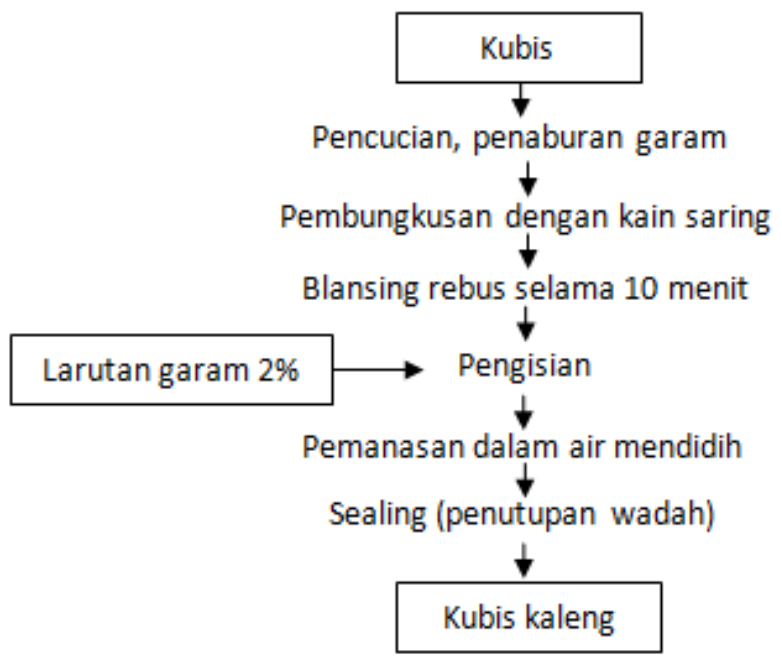

Gambar 8. Diagram Alir Pengalengan Kubis (Koswara, 2009) 


\section{B. Sawi}

Sawi merupakan komoditas sayuran yang penting di Indonesia dan tidak dapat dipisahkan dari kebutuhan seharihari di dalam konsumsi rumah tangga tanpa memperhatikan tingkat sosial. Ada beberapa jenis sawi yaitu sawi putih (Brassica pekinensis) disebut juga petsai, sawi hijau ( $B$. juncea) atau disebut juga sawi bakso dan sawi sendok ( $B$. chinensis) atau disebut juga pok coy. Selain memiliki keragaman jenis, sawi juga memiliki kandungan gizi yang cukup tinggi.

Alternatif pengolahan sawi cukup beragam diantaranya yaitu dikeringkan menjadi tepung sawi, diolah menjadi es krim, smootie, stik, mie hingga fermentasi sawi menjadi berbagai produk fermentasi seperti kimchi, fu-choy, mei-kan-choy dan chinese mustard.

\section{Tepung sawi}

Tepung merupakan produk awetan yang diperoleh dari proses penggilingan suatu bahan dalam bentuk butiran-butiran halus dengan kadar air 10-13 \% (Gambar 9). Tepung merupakan salah satu bentuk alternatif produk setengah jadi yang dianjurkan, karena mudah dicampur, diperkaya zat gizi (difortifikasi), mudah dibentuk, dan lebih cepat dimasak sesuai dengan tuntutan kehidupan modern yang serba praktis. Di samping itu teknologi pengolahan tepung juga sudah dikenal dan mudah diterima oleh masyarakat. 


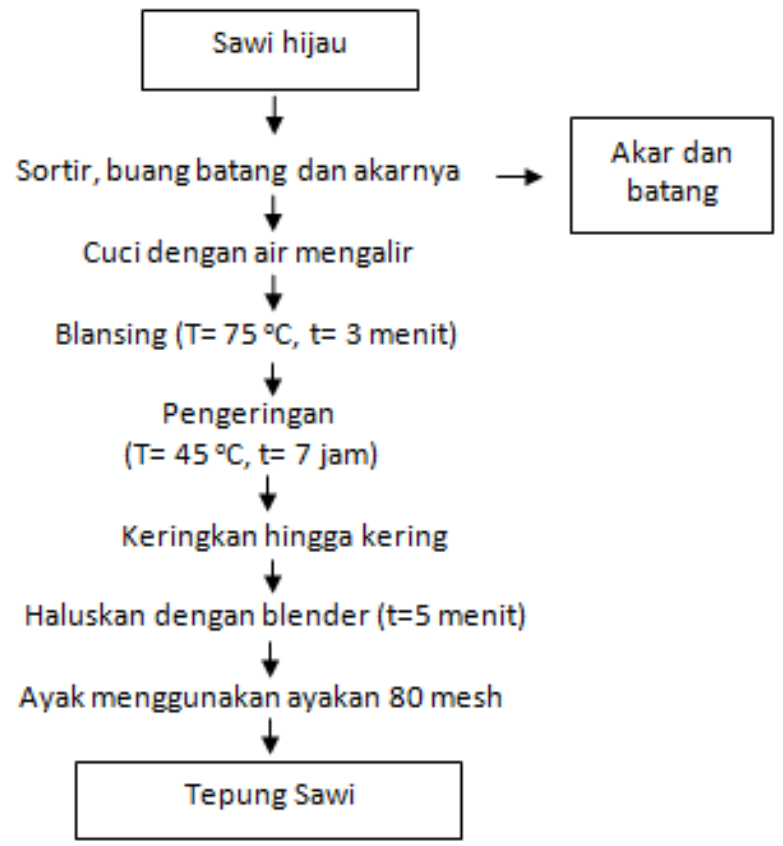

Gambar 9. Diagram Alir Pembuatan Tepung Sawi

2. Es krim sawi

Es krim adalah produk pangan beku yang dibuat melalui kombinasi proses pembekuan dan agitasi pada bahan-bahan yang terdiri dari susu dan produk susu, pemanis, penstabil, pengemulsi, serta penambah citarasa (flavor) (Gambar 10). Diversifikasi produk es krim berbahan sayuran menjadi alternatif untuk meningkatkan konsumsi sayuran. 


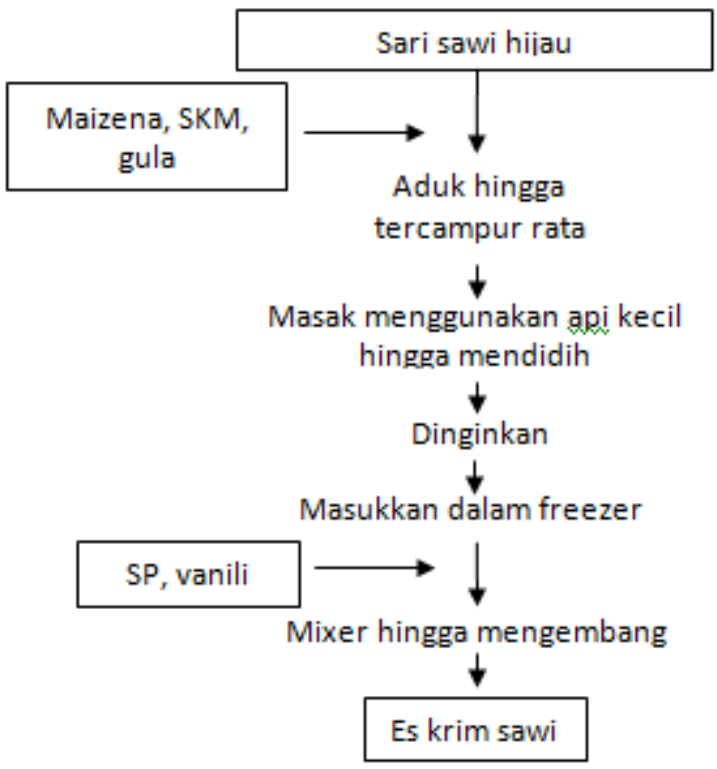

Gambar 10. Diagram Alir Pembuatan Es Krim Sawi (Widayanti dkk., 2018)

3. Smootie sawi

Smootie merupakan minuman yang terbuat dari buah dan atau sayur mentah menggunakan blender (Gambar 11). Tekstur smootie lebih creamy dan kental. Smootie sawi ini dapat dilakukan dengan berbagai cara salah satunya yaitu dengan pengolahan sayuran yang ditambahkan dengan tape, SKM (susu kental manis), dan gula untuk menghasilkan rasa yang berbeda. 


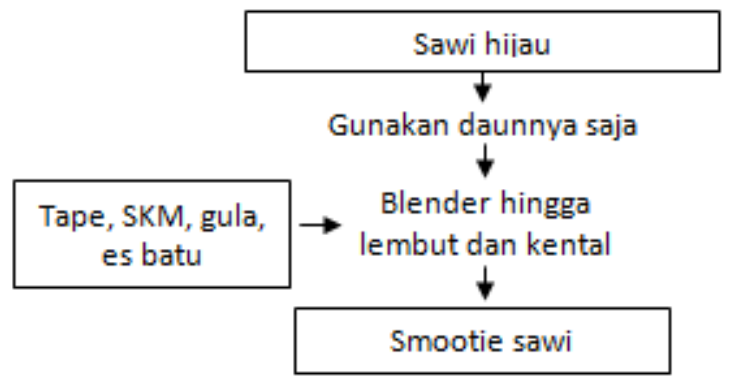

Gambar 11. Diagram Alir Pembuatan Smootie Sawi

(Widayanti dkk., 2018)

4. Mie sawi

Pengolahan sawi hijau menjadi bahan makanan lain, seperti mie hijau berpotensi untuk dikembangkan. Menu kuliner berbahan mie selalu menjadi menu favorit semua kalangan, dari anak kecil hingga dewasa menyukai masakan mie, karena cita rasa mie yang menggugah selera, juga menu mie yang mengenyangkan dan praktis dibuat. Jenis makanan olahan yang berbahan baku mie juga sangat banyak ragamnya, diantaranya mie ayam, mie ramen, mie goreng, mie pangsit, mie Aceh, mie Jawa, dan jenis kuliner mie yang lainnya (Gambar 12). 


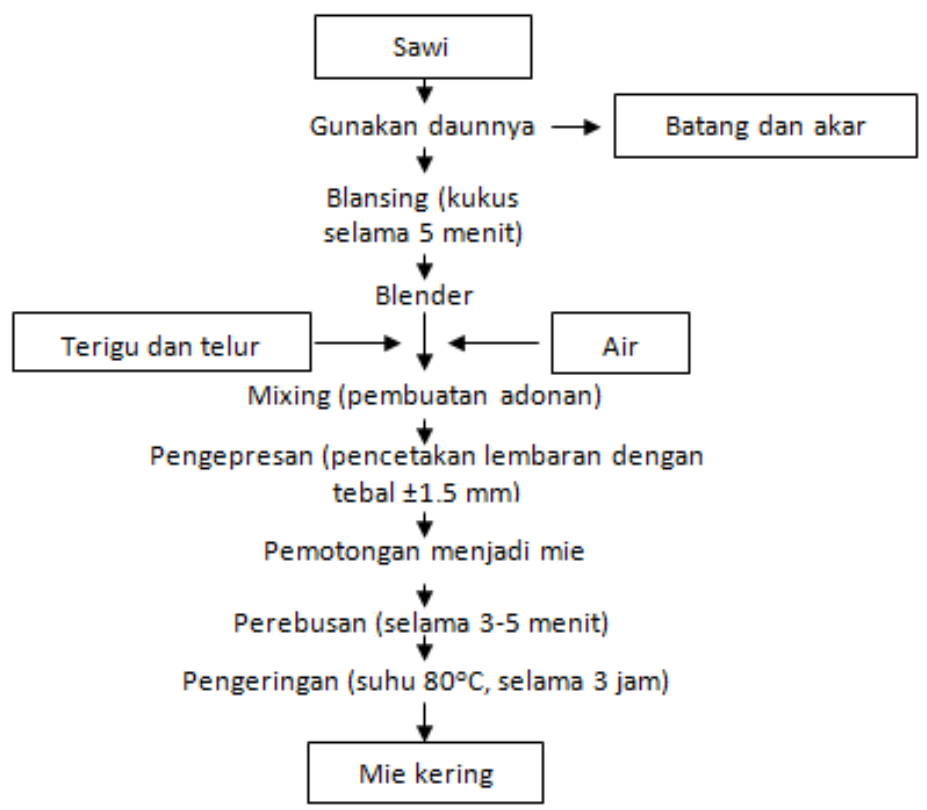

Gambar 12. Diagram alir Pembuatan Mie (Antarlina, 2016)

5. Sawi fermentasi

Fermentasi sayuran merupakan fermentasi spontan yaitu proses fermentasi tanpa menggunakan starter dan terjadi dengan sendirinya dengan bantuan mikroflora alami. Fermentasi sayuran dengan menggunakan garam sering pula disebut sebagai asinan. Karakteristik dari proses ini adalah adanya bakteri asam laktat yang berperan penting untuk menghasilkan produk dengan rasa dan aroma yang khas (Gambar 13). 


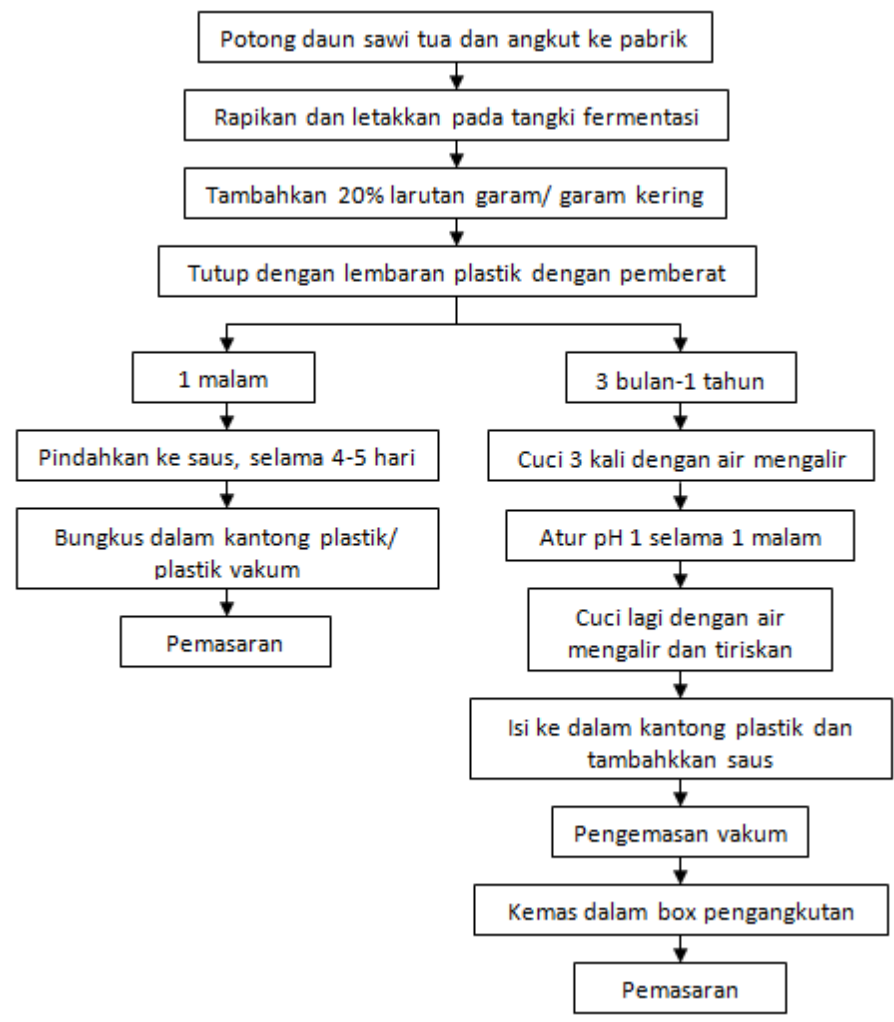

Gambar 13. Diagram Alir Umum Pengolahan Leaf Mustard Fermentasi (Srilaong, 2007) 


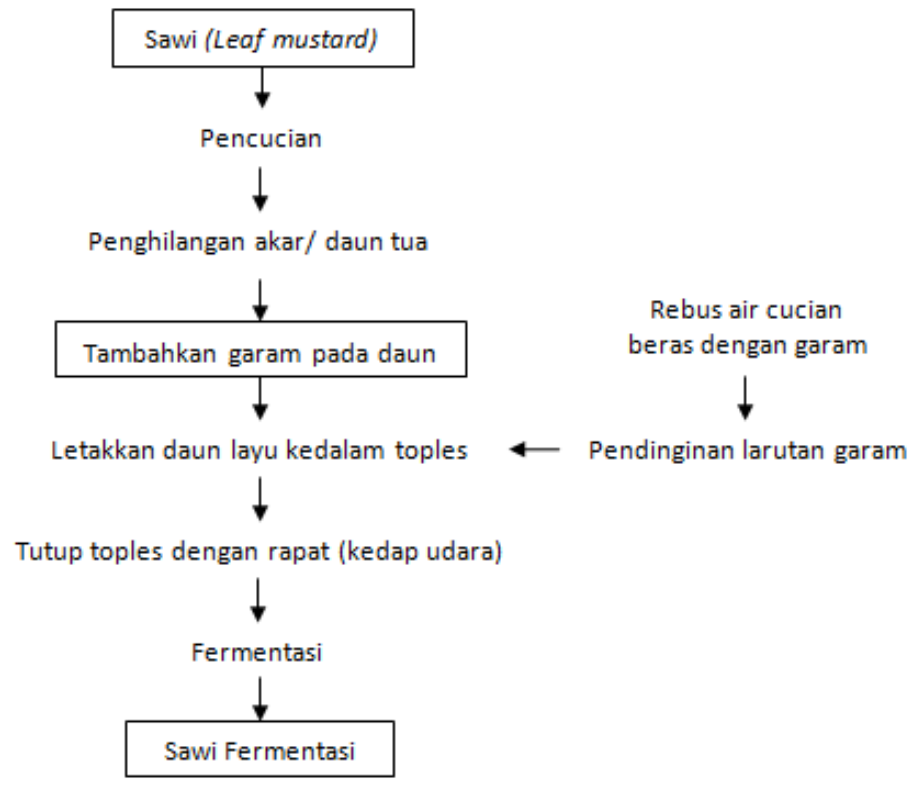

Gambar 14 Diagram Alir Pembuatan Sawi Fermentasi (Diamante, 2007) 


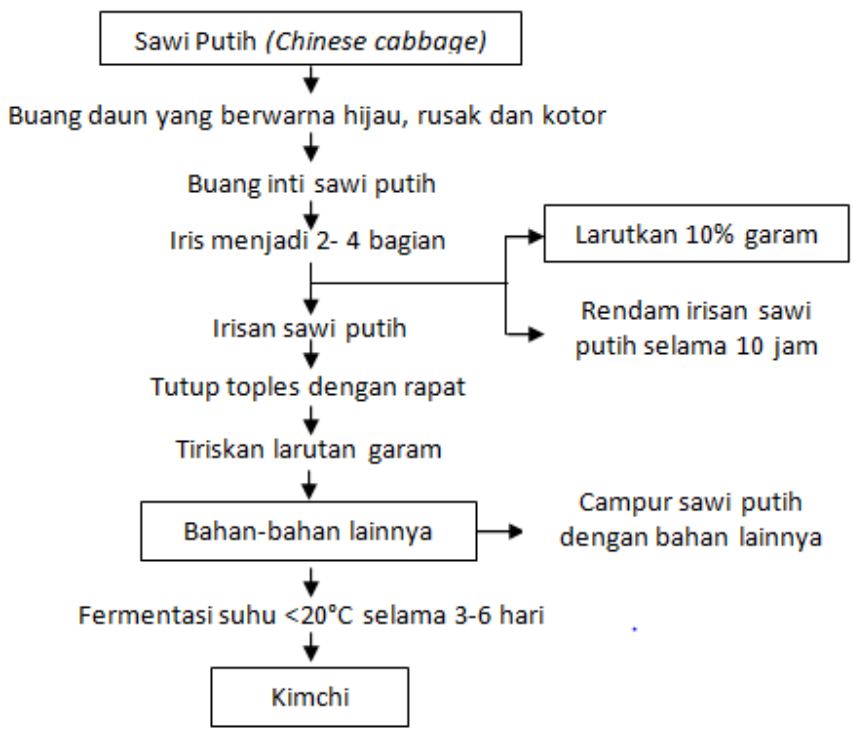

Gambar 15. Diagram Alir Pembuatan Kimchi Sawi (Diamante, 2007; Sasitorn, 2007) 


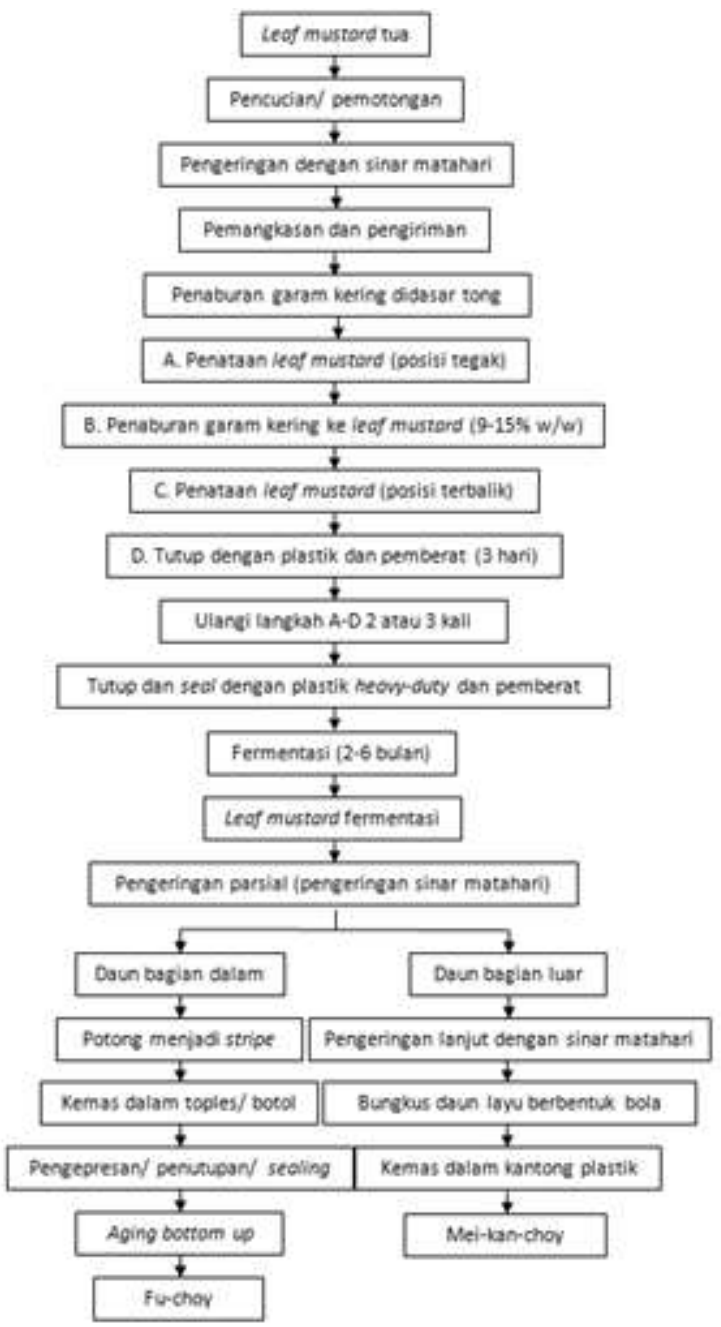

\section{Gambar 16. Diagram Alir Pembuatan Leaf Mustard fermentasi (Sasitorn, 2007)}




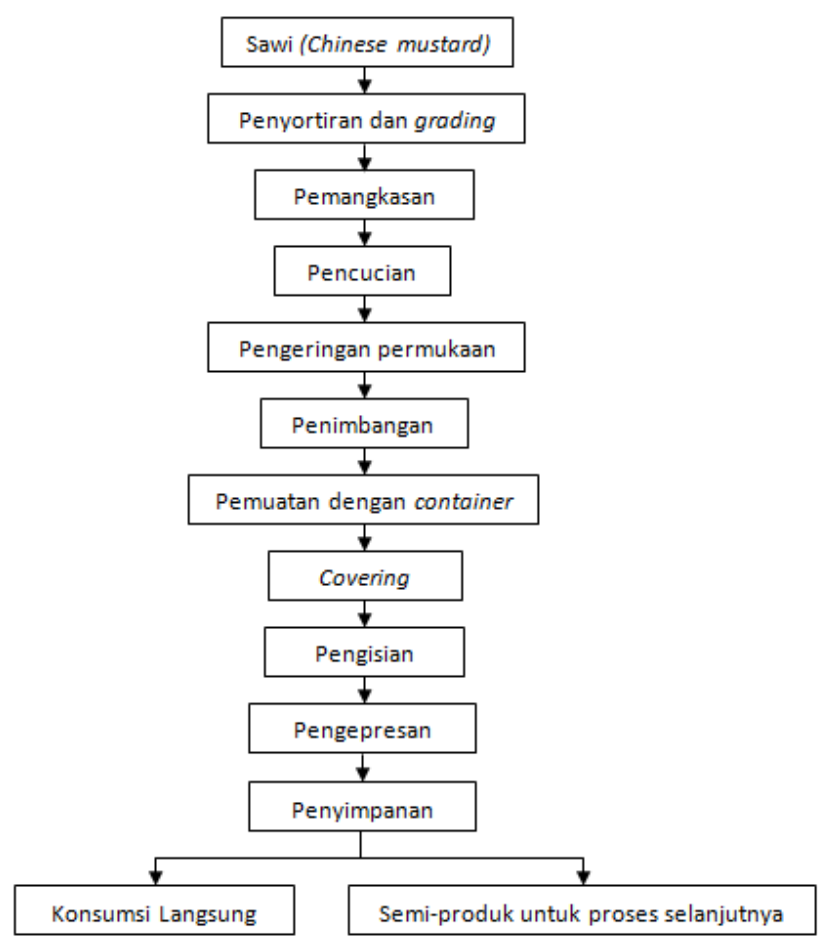

Gambar 17. Diagram Alir Teknik Fermentasi Chinese Mustard (Thanh, 2007)

\section{Daftar Pustaka}

Alifah, S., A. Nurfida, dan A. Hermawan. 2019. Pengolahan Sawi Hijau Menjadi Mie Hijau Yang Memiliki Nilai Ekonomis Tinggi di Desa Sukamanis Kecamatan Kadudampit Kabupaten Sukabumi. Journal of Empowerment Community 1 (2): 53-58. 
Antarlina, S. S. 2016. Formulasi Tepung Sukun, Pasta Sawi, Tomat dan Kulit Buah Naga pada Pembuatan Mie Basah. Prosiding Seminar Nasional Inovasi Teknologi Pertanian. Banjarbaru.

Hildayati, R. 2005. Pengaruh lama perendaman natrium metabisulfit $\left(\mathrm{Na}_{2} \mathrm{~S}_{2} \mathrm{O}_{5}\right)$ dan lama pengeringan terhadap mutu tepung sukun (Artocarpus communis). Skripsi. Universitas Sumatera Utara.

Kalla, R. dan R. Alam. 2019. Pengolahan Stik Sawi Hijau. Jurnal Pengabdian Bina Ukhuwah 1 (2): 33-36

Koswara, S. 2009. Teknologi Pengolahan Sayuran dan Buahbuahan (Teori dan Praktek). eBookpangan.com.

Lubis, I. H. 2008. Pengaruh Lama dan Suhu Pengeringan Terhadap Mutu Tepung Pandan. Skripsi. Universitas Sumatera Utara.

Putri, D. F. 2012. Pengaruh suhu dan lama pengeringan terhadap sifat kimia dan organoleptik tepung labu kuning (Cucurbita maxima). Skripsi. Fakultas Pertanian Universitas Lampung. Lampung.

Sangaji, Z. 2017. Kajian Sistem Budidaya Tanaman Sawi (Brassica juncea L ) di Petani Kelurahan Malawele Distrik Aimas Kabupaten Sorong. Jurnal Median 9 (1): 16-24.

Widayanti, N., S. Maimurni, D. S. Mulyadi, N. D. P. Ratnasari, S. Aisyah dan N. Syahria. 2018. Inovasi Pemanfaatan Sayuran Menjadi Smoothie dan Ice Cream Sayur. Jurnal Abadimas Adi Buana 2 (1): 48-53. 


\section{DAFTAR PUSTAKA}

Alifah, S., A. Nurfida, dan A. Hermawan. 2019. Pengolahan Sawi Hijau Menjadi Mie Hijau yang Memiliki Nilai Ekonomis Tinggi di Desa Sukamanis Kecamatan Kadudampit Kabupaten Sukabumi. Journal of Empowerment Community I (2): 52-58.

Asgar A., dan D. Musaddad. 2006. Optimalisasi Cara, Suhu, dan Lama Blansing Sebelum Pengeringan Pada Wortel. Jurnal Hort. XVI (3): 245-252.

Ayu, D. C. dan S. S. Yuwono. 2014. Pengaruh Suhu Blansing dan Lama Perendaman Terhadap Sifat Fisik Kimia Tepung Kimpul (Xanthosoma sagittifolium). Jurnal Pangan dan Agroindustri II (2): 110-120.

David, J. H. dan J. C. Kilmanun. 2016. Penanganan Pasca Panen Penyimpanan untuk Komoditas Hortikultura. Prosiding Seminar Nasional Inovasi Teknologi Pertanian. Banjarbaru.

Duvernay, M. 2014. Comparison of Water and Microwave Blanching of Mangoes and Sensory Evaluation dalam https://zenodo.org diakses Tanggal 21 Januari 2020.

Haerani, T. 2016. Pengaruh Penggunaan Berbagai Jenis Lampu terhadap Pertumbuhan Bayam (Amaranthus sp). Skripsi. Universitas Islam Negeri Alauddin Makassar. Makassar.

Handayani, L. 2014. Indeks Glikemik dan Beban Glikemik Vegetable Leather Brokoli (Brassica oleracea var. Italica) dengan Substitusi Inulin. Artikel Penelitian. Universitas Diponegoro. Semarang. 
Hayati, R., Syamsuddin, dan Halimursyadah. 2015. Teknologi Pasca Panen. Buku Ajar. Universitas Syiah Kuala. Banda Aceh.

Hidayat, T. 2019. Respon Tanaman Kangkung Darat (Ipomea reptans Poir.) terhadap Konsentrasi Pupuk Organik Cair NASA. Skripsi. Universitas Andalas. Padang.

Iwantari, A. 2012. Skripsi. Pengaruh Pemberian Biofertilizer dan Jenis Media Tanam terhadap Pertumbuhan da $\mathrm{n}$ Produktivitas Tanaman Kubis (Brassica oleracea). Universitas Airlangga. Surabaya.

Koeswardhani, M. 2016. Dasar-dasar Teknologi Pengolahan Pagan. Modul 1.

Koswara, S. 2009. Teknologi Pengolahan Sayuran dan Buahbuahan (Teori dan Praktek). eBookPangan.com.

Lubis, J. 2018. Pengaruh Pertumbuhan dan Produksi Tanaman Selada (Lactuca sativa L.) pada Sistem Hidroponik NFT dengan Berbagai Konsentrasi Pupuk AB Mix dan Bayfolan. Skripsi. Universitas medan Area. Medan.

Lukman, A. 2016. Uji Aktivitas Antibakteri Ekstrak Daun Kemangi (Ocimum sanctum L) Terhadap Bakteri Patogen Dengan Metode KLT Bioautografi. Skripsi. Universitas Islam Negeri Alauddin Makassar. Makassar.

Murtiwulandari, D. T. M. Archery, M. Haloho, R. Kinasih, L. H. S. Tanggara, Y. H. Hulu, K. Agaperesa, N. W. Khristanti, Y. Kristiyanto, S. S. Pamungkas, Y. A. Handoko, dan G. D. Y. Anarki. 2020. Pengaruh suhu penyimpanan terhadap kualitas hasil panen komoditas Brassicaceae. Media Informasi dan 
Komunikasi IImiah Teknologi Pertanian 11(2): 135143.

Nofriati, D. 2013. Teknologi Pascapanen Sayuran Daun. Balai Pengkajian Teknologi Pertanian (BPTP) Jambi. Jambi.

Nurhidayah, L. 2018. Perbedaan Pertumbuhan Tanaman Sawi Hijau (Brassica juncea L.) pada Media Tanam Hidroponik dan Media Tanah. Skripsi. Universitas Ialam Negeri Mataram. Mataram.

Oktaviani, A. L. 2011. Studi Optimalisasi Pre-Treatment Blanching dan Metode Pembekuan pada Brokoli (Brassica oleracea L. var. Italica). Skripsi. Universitas Katolik Soegijapranata. Semarang.

Pardede, E. 2009. Buah dan Sayur Olahan secara Minimalis. Jurnal VISI XVII (3): 245-254.

Puspitarini, B. A. 2010. Uji Aktivitas Antioksidan Ekstrak Daun Singkong (Manihotis folium) menggunakan Metode Diphenylpicryl Hydrazyl (DPPH). Skripsi. Universitas Sanata Dharma. Yogyakarta.

Samad, M. S. 2008. Pengaruh penanganan pasca panen terhadap mutu komoditas hortikultura. Jurnal Sains dan Teknologi Indonesia 8(1):31-36.

Sangaji, Z. 2017. Kajian Sistem Budidaya Tanaman Sawi (Brassica juncea L) Di Petani Kelurahan Malawele Distrik Aimas Kabupaten Sorong. Jurnal Median 9 (1): 16-24.

Sari, A. N. 2018. Efektivitas Daun Kemangi (Ocimum sanctum L.) Sebagai Ovisida Terhadap Nyamuk Aedes aegypti (Sebagai Bahan Penuntun Praktikum Biologi Materi Pencemaran Lingkungan pada Peserta Didik SMA 
Kelas X Semester Genap). Skripsi. Universitas Islam Negeri Raden Intan Lampung. Lampung.

Setyadjit, I. Agustinisari, Yulianingsih, dan D. A. Setyabudi. 2005. Peranan Teknologi Olahan Buah dalam Peningkatan Ekonomi Indonesia. Prosiding Seminar Nasional Teknologi Inovatif Pascapanen untuk Pengembangan Industri Berbasis Pertanian. Balai Besar Penelitian dan Pengembangan Pascapanen Pertanian. Jakarta.

Sudjatha, W. dan N. W. Wisaniyasa. 2017. Fisiologi da n Teknologi Pascapanen (Buah dan Sayuran). Udayana University Press. Denpasar.

Utama, I. M. S. dan N. S. Antara. Modul Kuliah. Pasca Panen Tanaman Tropika: Buah dan Sayur. Tropical Plant Curruculum Project. Universitas Udayana.

Utama, I. M. S. Kemunduran Produk Hortikultura Segar. Bahan Ajar 4. Fisiologi dan Teknik Pascapanen Hortikultura.

Wulansari, A. dan N. Sekar. 2017. Blanching. Laporan Praktikum. Universitas Jendral Soedirman. Purwokerto

Yohanis, B. 2008. Penanganan Pasca Panen yang Tepat untuk Mempertahankan Mutu Buah dan Sayur. Penyuluh Pertanian BPP Sesean Suloara Kab. Toraja Utara.

Yuarini, D. A. A., I. K. Satriawan, dan I. D. P. O. Suardi. 2015. Strategi Peningkatan Kualitas Produk Sayuran Segar Organik pada CV. Golden Leaf Farm Bali. Jurnal Manajemen Agribisnis 3 (2): 93-109.

Yulis, S. 2015. Formulasi Ekstrak Etanol Daun Kelor (Moringa oleifera L.) Pada Sediaan Krim Wajah Terhadap 
Bakteri Staphylococcus epidermidis. Skripsi. Institut Kesehatan Helvetia. Medan.

Zam, W., Ilyas, dan Syatrawati. 2019. Penerapan Teknologi Pascapanen untuk Meningkatkan Nilai Jual Cabai di Tanatoraja. Jurnal dedikasi Masyarakat 2 (2): 92-100. Azeliya, R. M. 2013. Pembuatan Bolu Brokoli (Brassica oleracea L) Dilihat dari Kadar Beta Karoten dan Kadar Vitamin C Serta Daya Terima. Naskah Publikasi. Universitas Muhammadiyah Surakarta. Surakarta. 


\section{BIODATA PENULIS}

Ir. Ida Agustini Saidi, MP. lahir di Denpasar, Bali 4 Agustus 1959. Lulus Sarjana Pertanian Jurusan Agronomi Institut Pertanian Bogor tahun 1982, melanjutkan studi S2 di Prodi Teknologi Pasca Panen Program Pascasarjana Universitas Brawijaya lulus tahun 1997. Karir pengajaran dimulai tahun 1983 di

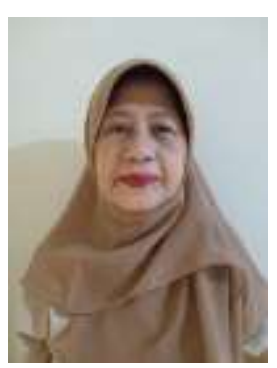
Fakultas Pertanian Universitas Udayana, Denpasar, tahun 1991 hingga tahun 2002 di Fakultas Pertanian Universitas Bangkalan Madura dan selanjutnya hingga sekarang di Universitas Muhammadiyah Sidoarjo.

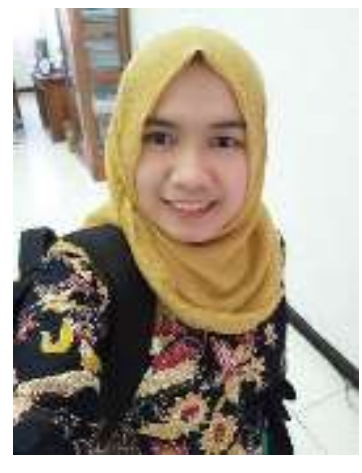

Rima Azara, S.TP, M.P. dilahirkan di Malang, 12 Januari 1990. Pendidikan dasar SD dan SMP diselesaikan di Wajak, Malang. Tahun 2008 penulis lulus dari SMA Negeri I Tumpang dan diterima di Universitas Brawijaya, Fakultas Teknologi Pertanian, Jurusan Ilmu dan Teknologi Pangan. Gelar Magister pada jurusan Teknologi Hasil Pertanian juga diperoleh di Universitas yang sama pada tahun 2013. Mulai tahun 2014 hingga sekarang, penulis menjadi dosen tetap di Universitas Muhammadiyah Sidoarjo. Matakuliah yang diampu penulis di prodi THP UMSIDA salah satunya adalah Mikrobiologi Pangan. 
Evi yanti, SP. lahir di Sidoarjo, 29 September 1982. Pendidikan dasar dan SMP di selesaikan di Sidoarjo. Tahun 2000 lulus dari Sekolah Kesehatan Angkatan Laut (SEKESAL) Surabaya. Tahun 2015 penulis melanjutkan kuliah di Universitas Muhammadiyah Sidoarjo jurusan Teknologi Hasil Pertanian (THP) dan mendapat gelar Sarjana Pertanian pada tahun 2019. Buku dengan judul "pasca panen dan pengolahan sayuran daun" ini merupakan karya pertama penulis. 
I59N $978-6236292-21-1$

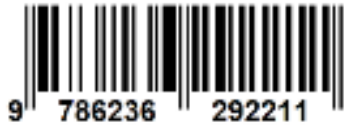

